UNIVERSIDADE DE SÃO PAULO

INSTITUTO DE PSICOLOGIA

FERNANDA FERRARI ARANTES

Indicadores de sucesso na inclusão escolar: um estudo exploratório

São Paulo

2013 
FERNANDA FERRARI ARANTES

Indicadores de sucesso na inclusão escolar:

Um estudo exploratório

São Paulo

2013 
FERNANDA FERRARI ARANTES

\title{
Indicadores de sucesso na inclusão escolar: um estudo exploratório
}

(Versão corrigida)

\begin{abstract}
Dissertação apresentada ao Instituto de Psicologia da Universidade de São Paulo, como parte dos requisitos para obtenção do grau de Mestre em Psicologia.

Área de concentração: Psicologia Escolar e do desenvolvimento humano.
\end{abstract}

Orientador: Prof. Dr. Rogério Lerner

São Paulo

2013 


\section{AUTORIZO A REPRODUÇÃO E DIVULGAÇÃO TOTAL OU PARCIAL DESTE TRABALHO, POR QUALQUER MEIO CONVENCIONAL OU ELETRÔNICO, PARA FINS DE ESTUDO E PESQUISA, DESDE QUE CITADA A FONTE.}

Catalogação na publicação

Biblioteca Dante Moreira Leite

Instituto de Psicologia da Universidade de São Paulo

Arantes, Fernanda Ferrari.

Indicadores de sucesso na inclusão escolar: um estudo exploratório / Fernanda Ferrari Arantes; orientador Rogério Lerner. -- São Paulo, 2013.

$157 \mathrm{f}$.

Dissertação (Mestrado - Programa de Pós-Graduação em Psicologia. Área de Concentração: Psicologia Escolar e do Desenvolvimento Humano) - Instituto de Psicologia da Universidade de São Paulo.

1. Inclusão escolar 2. Psicanálise 3. Educação I. Título. 
Nome: Ferrari Arantes, Fernanda

Título: Indicadores de sucesso na inclusão escolar: um estudo exploratório

Dissertação apresentada ao Instituto de Psicologia da Universidade de São Paulo para obtenção do título de Mestre em Psicologia

Aprovado em:

Banca Examinadora

Prof. Dr.

Instituição: Assinatura:

Prof. Dr.

Instituição: Assinatura:

Prof. Dr.

Instituição: Assinatura: 
Ao Gustavo, que com companheirismo, amor e sensibilidade me faz crescer a cada dia. 


\section{Agradecimentos}

Ao Prof. Dr. Rogério Lerner, pela orientação cuidadosa e por ter-me concedido a oportunidade de conceber este trabalho.

À Prof. Dra. Marie Claire Sekkel e ao Prof. Dr. Rinaldo Voltolini pelas leituras atenciosas, valiosas sugestões e férteis contribuições realizadas no exame de qualificação.

À equipe da Escola Viva, por me acompanhar nesse estimulante e difícil caminho, compartilhando e aprendendo diariamente, e pela possibilidade de um trabalho institucional tão instigante.

A todas as pessoas que, de uma maneira ou de outra, auxiliaram-me na realização deste trabalho. Amigos que se dispuseram a ouvir, contribuindo de maneira sensível para o amadurecimento e a estruturação das minhas ideias e concepções. Deixo aqui meus sinceros agradecimentos.

Ao Pedro, ao Felipe e a todas as crianças que, sem saber, me ensinaram que este caminho seria possível. 


\section{Resumo}

Arantes, F. F. (2013). Indicadores de sucesso na inclusão escolar: um estudo exploratório. Dissertação de Mestrado, Instituto de Psicologia, Universidade de São Paulo, São Paulo.

Esta dissertação é um estudo exploratório que parte de uma proposta de tomar elementos discursivos de entrevistas realizadas com educadoras que trabalham em escolas de educação infantil da cidade de São Paulo, para constituí-los como indicadores de sucesso da educação inclusiva. Parte-se de uma revisão de literatura a respeito das incidências da inclusão escolar e constata-se que, embora noções de sucesso não tenham sido mencionadas nos trabalhos analisados, há uma preocupação latente quanto ao sucesso e ao fracasso dos processos de inclusão escolar. Tomando este cenário como ponto de partida, buscamos abordar a maneira pela qual a educação inclusiva é entendida na atualidade, tecendo problematizações entre algumas das diferentes perspectivas que embasam esse tema, dentre as quais a psicanalítica mostrou-se uma significativa ferramenta para discutir a natureza das diferentes ocorrências da inclusão escolar, entre elas, os indicadores de sucesso. Procuramos situar "indicador" quanto ao seu conceito e realizamos uma breve apresentação da origem da utilização de indicadores nas pesquisas psicanalíticas. Esse material nos permitiu realizar uma analogia na elaboração dos indicadores de sucesso da inclusão escolar, o objetivo principal deste estudo. A partir do referencial teórico psicanalítico, mais precisamente a teoria lacaniana dos quatro discursos, pesquisamos, a partir de relatos colhidos com educadoras de educação infantil - tomados como elementos discursivos - os aspectos referentes a situações de sucesso dos processos inclusivos mencionados, para elaborar indicadores de sucesso da inclusão escolar. Os aspectos colhidos nas entrevistas nos mostram que se os educadores encontram-se implicados com o que é possível realizar no dia-a-dia e no aprendizado com a criança - no que é possível ser feito -, o processo inclusivo é caracterizado como bem sucedido. As entrevistas, portanto, fornecem dados que nos servem para a caracterização do possivel como um indicador de sucesso da inclusão escolar.

Palavras-chave: Inclusão escolar; Psicanálise; Educação; Singularidade. 


\begin{abstract}
Arantes, F. F. (2013). Indicators of success in school inclusion: an exploratory study, Master's Dissertation, Institute of Psychology, University of São Paulo, São Paulo

This dissertation is an exploratory study based on a proposal to take discursive elements from interviews conducted with educators who work in children's education schools in the city of São Paulo, and to establish them as indicators of success for inclusive education. It begins with a literature review concerning incidences of school inclusion and it ascertains that, although notions of success have not been mentioned in the studies analyzed, there is latent concern regarding success and failure of school inclusion processes.

Using this as a starting point, we seek to address how inclusive education is understood today, weaving problems among some of the different perspectives that are the foundation for this theme, among which psychoanalysis proved to be an important tool for discussing the nature of the different occurrences of school inclusion, including, success indicators. We tried to situate the "indicator" in relation to its concept and we conducted a brief presentation of the origin of indicator use in psychoanalytical studies. This material allowed us to make an analogy in the elaboration of success indicators for school inclusion, this study's main objective. Based on the psychoanalytic theoretical reference, more precisely the Lacanian theory of four discourses, we have researched, based on reports gathered from child education educators - taken as discoursives elements - the aspects that refer to situations of success for the inclusive processes mentioned, in order to develop indicators of success in school inclusion. The aspects collected from the interviews show us that, if educators are concerned with what is possible to do on their daily activities and on what they learn with the children - on what is possible to be done - the inclusive process is characterized as successful. The interviews, therefore, provide us with data that distinguishes the feasible as a success indicator of school inclusion.
\end{abstract}

Key Words: School inclusion; Psychoanalysis; Education; Singularity 


\section{Sumário}

1. Introdução 11

2. Educação inclusiva: inclusão total e inclusão possível 33

2.1 Inclusão escolar, heranças históricas e impasses contemporâneos 33

2.2 Uma perspectiva sociológica da inclusão 37

2.3 Uma perspectiva psicanalítica da inclusão $\quad 40$

3. Psicanálise, educação e a tentativa de entender a diferença 44

3.1 Contribuições da psicanálise para o entendimento da diferença 44

3.2 A diferença no contexto escolar 49

3.3 É possível nomear a diferença? $\quad 52$

4. Indicadores de sucesso na educação inclusiva 57

4.1 Sucesso e fracasso: que ideias são essas?

4.2 Indicadores: o que são? Para que servem? 59

4.3 Indicadores de sucesso na inclusão escolar 62

5. A educação infantil diante da educação inclusiva 64

5.1 Um histórico da educação infantil no Brasil 65

5.2 Por que pesquisar inclusão na educação infantil? 68

5.3 Uma questão ética $\quad 69$

5.4 Amostragem por saturação $\quad 72$

6. A teoria dos quatro discursos e a educação inclusiva 75

6.1 Inclusão escolar e os quatro discursos $\quad 84$

7. As Entrevistas $\quad 86$

7.1 A primeira instituição pesquisada $\quad 87$

$\begin{array}{ll}7.2 \text { Entrevistas I } & 90\end{array}$

7.2.a Luís Felipe $\quad 91$

$\begin{array}{ll}\text { 7.2.b Carolina } & 99\end{array}$

$\begin{array}{ll}\text { 7.2.c Caio } & 105\end{array}$

7.2.d João 113

$\begin{array}{ll}7.3 \text { Sobre a creche pesquisada } & 119\end{array}$

$\begin{array}{ll}\text { 7.3.a Catarina } & 124\end{array}$

7.3.b André $\quad 130$

8. Discussão 137

9. Consideracões finais 147

$\begin{array}{ll}\text { Referências bibliográficas } & 151\end{array}$ 


\section{Introdução}

É possível construir critérios para avaliar o processo de inclusão de uma criança com necessidades educacionais especiais ${ }^{1}$ em uma escola regular, a fim de melhor compreender impasses e sucessos?

Se levarmos em conta os impasses que se dão no cotidiano desse trabalho que envolve os educadores, os alunos, suas famílias e outros protagonistas dessa história - quais são as possibilidades para o alcance de seu sucesso?

Essas são algumas das questões que permeiam os campos da Psicanálise e da Educação e têm sido alvo constante de inúmeras reflexões, com o objetivo de alinhar o que propõe a legislação e o que é possível realizar na prática no campo da educação inclusiva.

Sabe-se que a inclusão escolar é uma oportunidade de debate de ideias importantes e fundamentais na área da Educação e vem apontando para o exercício da convivência social como uma maneira de lidar com a inflexibilidade diante das diferenças, mantendo assim, o objetivo de oferecer educação de qualidade para todos.

Quando falamos desse tema, estamos nos referindo à prática de incluir crianças que, durante muito tempo, estiveram fora do sistema regular de ensino e que passaram a receber respaldo político para pertencerem às "escolas comuns".

No entanto, a prática inclusiva, que vem acontecendo com frequência cada vez maior nas escolas regulares, se depara com impasses que levam a questionamentos sobre o seu significado, a condução e a validade de tal processo. Um deles é o fato de que apenas o amparo político — declarações, leis e diretrizes — não garante que o processo de inclusão aconteça de maneira adequada.

Quais seriam, então, os dispositivos necessários para que essa prática seja possível?

O movimento inclusivo é fruto de reflexões realizadas por educadores que buscaram encontrar opções em relação à incorporação — pelo sistema regular de

\footnotetext{
${ }^{1}$ Expressão introduzida em 1978 no Relatório de Warnock (Londres) e reafirmada na Declaração de Salamanca (1994). É o termo atribuído às crianças, jovens e adultos que apresentam os mais variados problemas relacionados à educação.
} 
ensino - das crianças que se encontravam excluídas do sistema. Tal movimento brotou no final da Segunda Guerra Mundial (1939-1945), quando as discussões a respeito da igualdade de direito entre os homens culminaram na Declaração Universal dos Direitos Humanos (1948).

Desde então, diversos pesquisadores tem se debruçado sobre o tema da inclusão, que percorreu um longo caminho de paradigmas e conceitos até alcançar o que é chamado hoje de educação inclusiva ${ }^{2}$, fato que levou às diversas formulações hoje existentes sobre essa prática nos campos da Psicanálise e da Educação.

No Brasil, o assunto vem sendo o foco de diversos estudos, pesquisas e debates principalmente nas duas últimas décadas. O movimento de integração social que surgiu para derrubar a prática da exclusão social das pessoas deficientes ganhou impulso na década de 1970. Da década de 1990 em diante, as ações em favor da educação inclusiva passaram a ter contornos mais definidos. Ao concordar com a Declaração Mundial de Educação para Todos: satisfação das necessidades básicas de aprendizagem, firmada em Jomtien (1990), na Tailândia, promovida pelo Banco Mundial, pela UNESCO e pelo Programa das Nações Unidas para o Desenvolvimento (PNUD), o Brasil fez a opção pela construção de um sistema educacional inclusivo. Em 1994, ao se tornar signatário da Declaração de Salamanca — produzida na Conferência Mundial sobre Necessidades Educacionais Especiais -, que introduziu mundialmente a perspectiva de uma Educação Inclusiva, o país reafirmou esse compromisso:

(...) as escolas deveriam acomodar todas as crianças, independentemente de suas condições físicas, intelectuais, sociais, emocionais, linguísticas ou outras. (...) As escolas devem buscar formas de educar tais crianças bem sucedidamente (...). O desafio que confronta a escola inclusiva é no que diz respeito ao desenvolvimento de uma pedagogia centrada na criança capaz de bem sucedidamente educar todas as crianças, incluindo aquelas que possuam desvantagens severas." (Brasil, 1997, p. 4).

Desde então, instalou-se no país um processo de transformações no sistema educacional, tendo como desdobramentos mudanças na legislação e na elaboração de diretrizes nacionais para a educação, todas elas norteadas pela ideia da educação inclusiva: os Parâmetros Curriculares Nacionais (PCN) - Adaptações Curriculares Estratégias para a educação de alunos com necessidades educacionais especiais (1998); anos mais tarde as Diretrizes para a Educação Especial na Educação Básica

\footnotetext{
${ }^{2}$ No capítulo 2 faremos uma breve explanação sobre a trajetória da educação inclusiva até a atualidade.
} 
em 2001, entre outras.

Segundo Jerusalinsky e Páez (2001) é possível considerar que o movimento de educação inclusiva veio tentar corrigir as controvérsias decorrentes das escolas especiais que, apesar de defenderem uma perspectiva integradora - movimento de aproximar as pessoas deficientes da comunidade - acabavam promovendo práticas sociais discriminatórias. A sua existência gerou uma barreira que dificultou a aceitação de muitas crianças nas escolas regulares que, embora tivessem problemas em seu desenvolvimento, apresentavam condições de se beneficiar da convivência com seus pares. Entretanto, a abertura dos portões das escolas comuns aos até então afetados - movimento mundialmente difundido embasado pela reivindicação dos direitos humanos - acabou promovendo uma nova forma de segregação:

(...) tem-se detido, de modo geral, os investimentos destinados a melhorar e aumentar a capacidade das escolas especiais (...) Ao mesmo tempo, são poucas as experiências onde se desenvolvem os recursos docentes e técnicos e o apoio específico necessário para adequar as instituições escolares (...) às novas condições de inclusão (Jerusalinsky \& Páez, 2001, p. 19).

Essa nova configuração escolar tem se deparado com impasses que se propagam e acabam promovendo o que podemos chamar por 'exclusão intramuros', passando para a sociedade a idéia de uma grande inclusão. De acordo com os autores citados, diversas crianças com problemas psíquicos, funcionais e de aprendizagem têm chegado à escola comum e enfrentado educadores clamando por formação específica, além da falta dos apoios adaptativos necessários. Tal circunstância leva as próprias crianças a terem que suportar a inadequação institucional e serem, consequentemente, responsabilizadas pelos incessantes fracassos educacionais e inclusivos.

Isso acaba ocorrendo porque as escolas esforçam-se por cumprir - de maneira apressada - aquilo que a legislação determina: escola para todos, e vêem-se às voltas com as diversas dúvidas que essa empreitada lhes desperta. Algumas instituições cumpriram com a lei e construíram mecanismos próprios de trazer para dentro da sala de aula as crianças até então segregadas, inventando, porém, formas de diferenciar o nível de seus alunos e justificar a inevitável separação.

Já outras se questionam a respeito da pertinência de ensinar aqueles que não conseguem aprender da mesma maneira que outros. Entretanto, a partir destas 
reflexões acabam se convencendo de que esse processo deve valer à pena e vão em busca de técnicas e meios de viabilizá-lo.

Kupfer e Petri (2000) abordam essa questão e afirmam que a escola moderna, na maneira como foi criada, fundou um contorno do "Real" que estabeleceu sua interioridade e sua exterioridade.

A criação da escola contorna então um Real e passa a dizê-lo. E, ao contornar o Real, pode passar a dizer o que ela não é, ou quem não são suas crianças. A escola encontra seus pontos de referência identitários nesse contorno, e o expedido pela instalação do contorno ajuda a defini-la" (Kupfer \& Petri, 2000, p. 112).

Ou seja, a escola precisa passar por radicais mudanças em suas estruturas e em seus princípios político-pedagógicos para ter condições de reintegrar aqueles que foram sendo sistematicamente excluídos do âmbito escolar.

O que é necessário fazer para que a inclusão aconteça e quais são suas possibilidades?

Ao longo desta dissertação, teremos a oportunidade de abordar os diversos movimentos que ocorrem no interior do campo da educação inclusiva, inclusive as tentativas de enquadrar as manifestações dos indivíduos considerados diferentes.

A proposta deste trabalho é a de refletir, a partir de operadores da Psicanálise, sobre a importância de elaborar indicadores de sucesso $^{3}$ da inclusão escolar que possam contribuir para os processos inclusivos que ocorrem diariamente nas escolas regulares.

O interesse em pesquisar sobre tais indicadores se alinha às pesquisas realizadas por Booth e Ainscow (2002) que culminaram na criação de um Index que verifica o quanto uma escola é inclusiva e o quanto ela pode vir a ser mais, por decisão de seus próprios integrantes.

Crochik et al. (2011) utilizaram o formulário criado pelo Index (2002) para verificarem a validade e a fidedignidade de seu conteúdo e constataram que os diversos indicadores apresentados no documento formam um conceito sobre o que é educação inclusiva:

(...) Booth e Ainscow (2002) priorizam a atenção para a escola em contraposição a outras concepções que focalizam nos alunos em situação de inclusão as dificuldades a 3 Entendendo indicador de sucesso como aquilo que pode fornecer indicações (de presença ou
ausência) de uma condição específica, no caso, o sucesso dos processos inclusivos escolares. 
serem superadas. Na sua concepção, os obstáculos ao aprendizado e à participação de todos os alunos são tidos como desafios da escola. (Booth \& Ainscow, 2002, p. 72)

Apesar de haver proximidades entre os entre os objetivos da presente pesquisa e a realizada por Booth e Ainscow (2002), diferentemente desta última, serão utilizados os referenciais psicanalíticos da teoria lacaniana dos quatros discursos para identificar os indicadores de sucesso da inclusão escolar. Pretendemos considerar seus efeitos para a produção e reconhecimento de singularidades como um possível indicador de sucesso.

A teoria dos quatro discursos formulada por Lacan $(1969,1970)$ introduz quatro maneiras de se estabelecer o laço social, que vieram sobrepor-se às três profissões impossíveis citadas por Freud ${ }^{4}(1925,1937)$. A elas, Lacan acrescentou uma outra modalidade de laço: o fazer desejar, completando, desse modo, as quatro maneiras de nos relacionarmos com o outro, inaugurando quatro modalidades de discurso. Como afirma Lacan (1969/1970) “(...) por que governar, educar, analisar e — por que não? — fazer desejar (...) são operações que, falando propriamente, são impossíveis (...) que só se definem no real por só poderem ser articuladas, quando nos aproximamos delas, como impossíveis" (p. 183).

Segundo Pereira (2005):

(...) tal teoria tem sido considerada um dos instrumentos mais ativos para a psicanálise, pois se interessa pelo que o sujeito produz em seu enlaçamento com a ordem social (Pereira, 2005, p. 104).

Ao abordar o laço social, essa teoria nos permite dialogar com outros campos do saber e pode ser um instrumento essencial para pensar o trabalho nas instituições educacionais.

Sobre a possibilidade da relação entre a interdisciplina e os quatro discursos, Jerusalinsky (1999) destaca que:

Desde o momento em que J. Lacan formula sua proposição dos quatro discursos ficam definitivamente estabelecidas, por um lado, as bases lógicas de toda e qualquer prática psicanalítica interdisciplinar, e, por outro lado, a impossibilidade de alguém vir a lograr que a psicanálise se transforme no seu patrimônio particular (...) fica fundamentado que a psicanálise não é mais do que uma variante do discurso (...) ela passa a ser patrimônio do discurso social e não mais propriedade particular de um certo ofício ou profissão (Jerusalinsky, 1999, p. 8).

\footnotetext{
${ }^{4}$ Educar, Governar e Analisar, que serão retomadas nos capítulo 5.
} 
E completa:

(...) o discurso psicanalítico não é mais do que uma consequência do necessário giro dos elementos que compõem o ato da prática social da linguagem - que sua prática não é exclusivamente apropriável para um determinado e fechado número de iniciados, mas que num certo sentido, ela é relativamente inevitável como eventual lugar de passagem de qualquer prática discursiva (Jerusalinsky, 1999, p. 8).

Portanto, ao promover o diálogo entre os campos da Psicanálise e da Educação para pensar a prática da inclusão escolar, temos a hipótese de que, ao utilizarmos tal teoria lacaniana como método de análise, será possível identificar, dentro daquilo que essa teoria pode fornecer alguns indicadores de sucesso da inclusão escolar e respectivamente seus eixos moduladores.

Falar sobre noções de sucesso e, consequentemente, de fracasso, independente do campo no qual se pretende abordá-los, é bastante delicado. Isso porque são noções que, a priori e de maneira vulgar, nos remetem aos imediatismos relativos ao alcance de êxito ou ao seu revés, a falha. Nesta pesquisa, esses dois termos serão intensamente utilizados, principalmente porque seu objetivo geral é elaborar indicadores de sucesso dos processos de inclusão escolar. De acordo com o que será apresentado e discutido mais adiante, tais noções estarão relacionadas ao que diz respeito à singularidade reconhecida e valorizada bem como as possibilidades da educação inclusiva.

Além dos estudos relativos à inclusão já citados, outros trabalhos têm sido propostos para investigar a perspectiva inclusiva e, entre eles, encontramos os que investigam a partir do viés psicanalítico. Muitos indicam diversas questões referentes à inclusão de alunos com necessidades educacionais especiais na escola comum, apontam para as adversidades que surgem neste campo e para os possíveis efeitos subjetivos desse processo nos alunos que apresentam particularidades no estabelecimento do laço social e no processo de aprendizagem. Demonstram estratégias utilizadas pelos professores, dificuldades de se lidar com a diferença, e diversas outras interrogações que irrompem quando se decide discutir o tema da inclusão escolar.

Entretanto, apesar da diversa gama de estudos levantados, não foram encontradas noções de sucesso e de fracasso como objetivos de pesquisa no campo da educação inclusiva. Embora não fossem os objetivos principais dos pesquisadores, foi possível identificar indicadores de sucesso e de fracasso apontados pelos autores, o que pôde contribuir sensivelmente para a delimitação do campo desta investigação. 
Rahme (2010) pesquisou o estabelecimento de laços entre as crianças num contexto escolar dito inclusivo, em especial em alunos que apresentam necessidades educacionais especiais, considerando seus efeitos para o sujeito. Partiu do princípio de que o laço social estabelecido entre pares pode ser algo positivo para a criança em situação de inclusão. Ao longo da discussão sobre o conceito de laço social, que partiram das formulações de Freud a respeito da estranheza nas relações entre os seres humanos e seus efeitos para a civilização $(1919,1921,1930)$ e da teoria lacaniana dos quatro discursos, pode-se identificar como indício de sucesso o fato de que a escola, ao reconhecer a criança em sua singularidade (e com suas necessidades particulares) facilitou a mudança de posição que era assumida por ela até então. O grupo de crianças do qual o menino fazia parte, supondo saberes sobre ele, funcionou como um elemento de organização subjetiva:

\footnotetext{
Valendo-se de seus saberes sobre Davi, as crianças propunham-lhe corridas, cantavam músicas, chamavam-no para tomar água ou jogar, realizando um movimento singular de operação com o simbólico. Além disso, a ocorrência de contenções por meio da palavra e do corpo se mostrou particularmente visível e nos permite indicar, como hipótese, que a turma possa ter funcionado para Davi como um elemento de organização subjetiva. (Rahme, 2010, p. 314)
}

Partindo do pressuposto defendido pela autora, de que o laço social entre pares pode ser benéfico para a criança em situação de inclusão, esse recorte aponta para um indício de sucesso da inclusão, tendo como referência a criança e o grupo.

De maneira geral, a autora discute que a concepção de que a inclusão possa ser construída a partir de manuais, extrai do debate as dimensões de invenção e criatividade (autoria) da prática profissional, pois reduz a possibilidade de alargar os limites da escola em relação ao encontro dos que são diferentes (Rahme, 2010, p. 333). Constata que estar na escola e compartilhar espaços de convivência comum pode significar a vivência de uma experiência intersubjetiva importante, de acordo com a análise do caso por ela apresentado:

(...) o que da intervenção criança-criança poderia nos auxiliar a pensar na intervenção adulto-criança na escola, em particular com crianças que apresentam especificidades na sua constituição subjetiva (Rahme, 2010, p. 333).

E, por fim, destaca uma questão bastante importante a respeito da prática inclusiva: 
(...) talvez seja mais apropriado pensarmos em práticas de acolhimento ao outro no contexto escolar do que a inclusão como um imperativo a ser cumprido. E esse fato não minimiza a importância de haver orientações legislativas nem a pertinência de existirem políticas educacionais voltadas para a garantia do direito à educação para todos (...) mas nos permite pensar no que excede o movimento de implementação da Educação Inclusiva como política educacional (Rahme, 2010, p. 334).

A reflexão de Rahme (2010) sobre as possibilidades da inclusão, pode desdobrar-se na seguinte questão: se a escola não se questiona sobre as práticas adotadas e não reflete sobre sua posição no discurso social, e, portanto, sobre sua relação com as diferenças, é possível falar em inclusão?

Dessa interrogação é possível extrair indicadores de sucesso, pois evidencia que, para uma escola trabalhar na perspectiva inclusiva e falar de inclusão, é necessário refletir constantemente sobre sua prática e sua posição no discurso social, caso contrário, corre-se o risco de intentar falar em inclusão, mas não conseguir exercê-la na prática.

$\mathrm{Na}$ mesma linha de pesquisa que Rahme, embora com referencial teórico distinto, Anhão (2009), também buscou verificar e analisar o modo pelo qual se dá o processo de interação social entre crianças com Síndrome de Down e crianças com desenvolvimento típico ${ }^{5}$ na rede regular de educação infantil. Em sua pesquisa, constatou que crianças com Síndrome de Down têm maior tendência a imitar os comportamentos apresentados por outras crianças, ao invés de buscar o seu "modelo" de atuação junto aos educadores. Diante disso, destacou a importância do ambiente escolar regular no processo de inclusão, uma vez que possibilita um maior contato da criança em situação de inclusão com outras crianças de desenvolvimento típico, na mesma faixa etária, o que não ocorre em ambientes segregados, como no caso do ensino especial. Dessa maneira, reforça a política de inclusão enfatizando a importância do convívio social como um fator benéfico para o desenvolvimento infantil, principalmente entre os três e seis anos de idade. Desse estudo, podemos extrair como indício de sucesso o fato de que:

\footnotetext{
5 Termo utilizado pela pesquisadora.
} 
(...) nesta faixa etária do desenvolvimento infantil, a convivência de crianças com SD em ambientes inclusivos é muito produtiva para o seu processo de desenvolvimento geral. (Anhão, 2009, p. 75).

Em sua pesquisa, Leodoro (2008) teve como objetivo analisar o material de formação do Programa educação inclusiva: direito à diversidade, a partir de 2003, realizado em âmbito nacional pela Secretaria de Educação Especial do Ministério da Educação. Utilizando-se da técnica da análise do discurso, propôs verificar quais seriam as contribuições do material pesquisado para a formação docente e a educação inclusiva. Constatou que o programa, ao proporcionar subsídios teóricos e materiais de formação, contribuiu para o crescimento das matrículas de alunos com necessidades educacionais especiais em classes e escolas comuns do ensino regular. Entretanto, após analisar os benefícios do programa, faz uma ressalva final, afirmando que apenas o material não basta para tornar um profissional, escola ou município inclusivista, uma vez que a inclusão escolar deve ser compreendida como um processo interminável, que não pode se realizar somente a partir de decretos, leis e declarações:

Evidentemente, a realização de um programa não basta para tornar um profissional, escola ou município inclusivista; a inclusão escolar deve ser compreendida, de acordo com Carvalho (2005), como um processo interminável, que não se realiza por decreto ou modismo (...) (Leodoro, 2008, p. 105).

A pesquisadora não menciona em nenhum momento indicadores de sucesso ou fracasso na educação inclusiva, pois este não era o seu objetivo de pesquisa. Mas é possível entender, a partir de suas reflexões, que para um ambiente escolar trabalhar com a inclusão, é necessário muito mais do que manuais que ensinem o método de como se trabalhar a inclusão.

Embora Leodoro (2008) fundamente a sua pesquisa em outro referencial teórico, apresenta uma leitura bastante importante desse movimento, aproximando-se do que é ressaltado por Kupfer e Petri (2000):

É necessário muito mais do que uma reformulação de espaço físico, de conteúdo programático ou de ritmos de aprendizagem, ou uma maior preparação do professor. (Kupfer \& Petri, 2000, p. 112). 
A partir de um estudo sobre a inclusão escolar e educacional de uma criança cega congênita com problemas na sua constituição subjetiva e no desenvolvimento global, Ormelezzi (2006) pretende chamar a atenção para a ênfase dada pelos psicanalistas, ingleses e norte-americanos, a respeito da primazia da visão na construção da vida psíquica da criança cega. Aponta que questões ligadas ao atraso motor e à imobilidade são, geralmente, questões centrais nas pesquisas realizadas com crianças cegas e pouco se fala sobre a constituição subjetiva.

A autora ressalta como objetivo principal de seu estudo, sustentado pela teoria da psicanálise lacaniana, conhecer algumas especificidades da criança cega que apresentam falhas na constituição subjetiva para oferecer auxílio aos educadores e instituições que trabalhem na perspectiva inclusiva com estas crianças. Ormelezzi (2006) faz questão de frisar que existem alguns impasses para atingir seu objetivo e um deles refere-se à enorme dificuldade de viabilizar a educação para todos, decretada nas declarações que contemplam esse objetivo, já que a concepção que vigora na escola ainda é aquela na qual a criança é avaliada pelo seu desempenho. E afirma:

Não obstante esse impasse, o objetivo desta tese permanece considerando que o lugar da escola não pode ser apenas o de transmissão de conhecimento, desvinculado do lugar social que ela representa em nossa cultura. Nesse sentido frisamos que a motivação inicial e a relevância social desta pesquisa reside no âmbito da inclusão educacional e escolar dessas crianças. (Ormelezzi, 2006, p. 27).

Embora não mencione os conceitos de sucesso da inclusão escolar, diante do estudo de Ormelezzi (2006) é possível identificar uma evidência de sucesso quando afirma que a Psicanálise pode oferecer fundamentos para a transdisciplinaridade com o campo da Educação podendo fornecer ao educador subsídios que "possibilitem uma intervenção pedagógica atenta às singularidades da criança". E continua sua reflexão, afirmando que a inclusão dessas crianças é um grande desafio que só será alcançado com a maturidade dos profissionais envolvidos, muito estudo, capacidade de análise da situação e criatividade para elaboração e adaptação das propostas educativas e participação efetiva das famílias nos processos de avaliação e das decisões a serem tomadas (Ormelezzi, 2006, p. 28).

Ao longo da discussão apresentada na tese, não foi possível extrair nenhum indício de fracasso no âmbito da inclusão escolar. Mesmo tendo como objetivo fornecer subsídios para o trabalho com a educação inclusiva, com o escopo definido, a autora (idem) se deparou com alguns limites em relação à abrangência do tema, mas 
que não demonstraram ser evidências de fracasso - de acordo com o conceito que esta pesquisa pretende abordar — no processo inclusivo.

Prioste (2006) buscou identificar as adversidades produzidas no ambiente escolar mediante as propostas textuais da educação inclusiva e se deparou com resultados que apontam para a dificuldade no estabelecimento de laços sociais entre professores e alunos. Dificuldades decorrentes das condições de trabalho desfavoráveis e das crenças estereotipadas relacionadas às crianças consideradas diferentes. A autora constatou que diante da angústia em relação a estes estranhamentos, tende-se a criar alteridades radicais que visam à exclusão da subjetividade do outro considerado estranho. Além disso, acrescenta que as crianças que não se enquadram nos padrões de normalidade socialmente construídos, quando frequentam classes regulares, recebem o rótulo de "incluídas", ainda que permaneçam à margem das interações e investimentos pedagógicos.

Sendo nomeada de incluída, a criança passa a ocupar um lugar subjetivo específico nas relações escolares, um lugar de estrangeiro que carrega consigo os estigmas que lhe foram impingidos. (Prioste, 2006, p. 154; grifo da autora).

Ao longo da pesquisa, embasada teoricamente na psicanálise lacaniana, Prioste (2006) assinala que a queixa apresentada pelos professores encobre manifestações conflituosas que revelam uma recusa em receber não apenas crianças com deficiência mental como também aquelas com distúrbios de conduta ou problemas de comportamento. Junto às queixas vem um pedido de ajuda, uma solicitação de suporte que, muitas vezes, está relacionada a anteparos na relação com a criança que não se ajusta ao padrão imaginário descrito nas teorias psicológicas do desenvolvimento. Nota que as queixas reveladas pelos educadores demonstram um despreparo da escola para lidar com a alteridade, fruto da diversidade.

A partir da explanação da pesquisadora, é possível identificar índices de fracasso que surgem da dificuldade no estabelecimento de laços sociais entre professores e alunos, decorrentes das condições de trabalho desfavoráveis e das crenças relacionadas às crianças consideradas diferentes. Tal situação é colocada pelos educadores como uma falta de suporte da escola o que deflagra a má condução dos processos inclusivos. Como uma possível solução, a autora propõe a existência de um espaço dedicado à travessia do mal-estar do educador (pois a cura da angústia é impossível), que implica na criação de um espaço de escuta do professor (escutar, ser 
escutado e se escutar), onde este possa expor seus medos e dúvidas a cerca das crianças e de suas ações pedagógicas. Um espaço para deixar emergir o conflito onde se possa pensar a relação com o aluno em sua singularidade:

A travessia do mal-estar implica primeiramente na criação de um espaço em que o professor possa ser escutado e, ao ser escutado, possa ele mesmo se escutar. Um espaço para que ele possa expor seus medos (...) um espaço onde se possa deixar emergir o conflito simbolizando seu mal-estar. Um espaço em que o professor possa pensar a relação com seu aluno em sua singularidade (Prioste, 2006, p. 150)

Ainda que tal proposição seja apenas uma sugestão da pesquisadora, com base nos resultados constatados é possível tomar essa proposta como uma das formas de atingir o sucesso na inclusão escolar caso se considere que, para tornar o estranho um pouco menos estranho e um pouco mais familiar, é necessária uma rede de suporte interna capaz de acolher as manifestações conflituosas que permeiam as instituições escolares.

Nessa mesma linha de pensamento, a respeito de espaços necessários para a escuta do professor, Bastos (2003) fundamentou uma leitura psicanalítica da escuta de professores de crianças com $\mathrm{DGD}^{6}$, com o objetivo de propiciar novas formas de ensino e aprendizagem que viabilizassem o trabalho com a inclusão escolar. Dessa maneira, buscou referenciais no histórico da educação inclusiva e na escuta dos impasses vividos pelos professores no trabalho com a inclusão.

A pesquisa realizada a partir de fragmentos recortados das reuniões de professores promovidas pelo Grupo Ponte, da Pré-Escola Terapêutica Lugar de Vida, aponta para o fato de que a escuta de professores, pautada pelo referencial psicanalítico, viabiliza a inclusão escolar de crianças com DGD, além de contribuir para a direção de seus tratamentos, uma vez que promove a circulação social como alunas da escola regular. A autora propõe um trabalho possível com educadores, composto pela escuta psicanalítica e por intervenções específicas. Tal proposta tem o objetivo de localizar a posição do aluno na estrutura discursiva da escola, propiciando novas formas de encaminhamento das práticas educativas, tornando possível o trabalho com inclusão escolar de crianças que apresentam dificuldades específicas.

\footnotetext{
${ }^{6}$ Nomenclatura introduzida pela revisão da terceira versão do Manual de Diagnóstico e Estatística da Associação Norte-americana de Psiquiatria III (DSM-III-R), 1980, que pretende indicar o comprometimento de múltiplas funções como habilidades sociais, linguagem, atenção, percepção, motricidade e teste de realidade.
} 
O que se põe em ação, a partir da escuta analítica dessas produções discursivas trazidas pelos professores, é a possibilidade de que nossas intervenções atuem na dinâmica que precipita a báscula de um discurso para outro. (Bastos, 2003, p. 97).

Assim, como os trabalhos acima apresentados até o momento, a pesquisa de Bastos (2003), que procurou utilizar-se da teoria dos quatro discursos proposta por Lacan (1969/1970) para promover na escuta de professores uma possível saída para a inclusão escolar, também não leva em consideração as noções de sucesso e fracasso na inclusão escolar. No entanto, indica que um espaço dedicado à escuta dos professores, atravessado pela leitura psicanalítica, faz com que o educador tenha que se a ver com o seu dito, com a sua queixa e seja, portanto, lançado a criar o seu próprio fazer educativo, pautado na singularidade de seu aluno. Aqui também é possível extrair como um traço de sucesso a existência de um espaço no qual possam circular as queixas dos professores pois, através da escuta analítica, as queixas podem ser transformadas em questionamentos da prática e, assim, possibilitar novas maneiras de encaminhar os processos inclusivos.

O trabalho desenvolvido por Emilio (2004), apoiado no referencial psicanalítico, também traz considerações importantes a cerca do que pode ser pensado como sucesso na educação inclusiva e propõe questões relevantes sobre essa temática, ainda que não seja seu objetivo identificar tais noções e, sim, mostrar um olhar sobre o avesso do cotidiano escolar, propondo reflexões sobre as amarras que incidem sobre o processo de inclusão.

Sem abordar diretamente a questão de sucesso, a autora aponta como facilitador o fato de existir uma psicóloga escolar na instituição pesquisada e, sobretudo, a sua atuação na direção de acolher os conteúdos (nem sempre desejáveis) trazidos pelos professores. Considera como ponto fundamental o trabalho com grupos pequenos de alunos, não apenas para melhorar a qualidade como também a realização de atividades diferenciadas para os alunos com necessidades educacionais especiais. Por fim, enfatiza a diferença entre a inclusão possível e a desejável, e afirma que ela só é possível quando a escola considera a proposta de forma ampla caracterizada pela maneira como se dá o convívio em grupo. Dessa maneira, após os dados coletados e as análises realizadas, Emilio (2004) propõe que, para alcançar e manter a inclusão possível, é necessário estabelecer um departamento de psicologia dentro da escola (que, de acordo com a pesquisa, foi crescendo aos poucos), responsável por alinhavar 
e acolher angústias dos professores, alunos e famílias e por pensar em possíveis encaminhamentos para os determinados casos, o que na instituição pesquisada, culminou na criação de uma nova função: professor-tutor.

Emilio (2004) defende que, para promover a inclusão, a escola precisa estar aberta para que isso ocorra, disposta para enfrentar os problemas e as dificuldades que isso causa, criando espaços onde se explicite as resistências a essas propostas:

(...) parece que a educação que objetiva transformações sociais somente poderá ocorrer em um contexto no qual os espaços de escuta e de decisões conjuntas sejam criados e possam sobreviver aos movimentos a eles contrários, a partir da revisão e reflexão constantes e do enfrentamento às dificuldades, inerentes ao convívio em sociedade (Emilio, 2004, p. 235).

Ao contrário das evidências ${ }^{7}$ em relação ao sucesso da inclusão escolar, questões sobre o fracasso quase não são abordadas. Através de vinhetas do cotidiano escolar, Emílio (2004) expõe algumas situações que possivelmente levariam ao fracasso quando pensados sob a ótica da inclusão escolar. Dentre eles, encontramos a grande dificuldade das crianças em situação de inclusão de pertencerem ao contexto escolar, marcadas por inúmeras mudanças de grupo, período escolar, e de instituições. Frisa que o fato de o aluno ser capaz de acompanhar as atividades do ano ao qual pertence não é suficiente para que a inclusão esteja garantida. E, por fim, constata também, a partir dos casos pesquisados, que mais de um aluno com necessidades educacionais especiais por classe sobrecarrega o grupo e os professores.

Sekkel (2003) estudou as determinações presentes no processo de inclusão de crianças com necessidades educacionais especiais a partir das experiências desenvolvidas na Creche Oeste da Universidade de São Paulo, iluminando os alicerces de um instrumento teórico-metodológico que permitiu avançar na inclusão de cada criança e no desenvolvimento de um projeto social-democrático.

A partir das entrevistas realizadas com os educadores da creche, Sekkel (2003) constata que os relatos colhidos revelam medo, o que contribui para a manutenção do estereótipo do preconceito. Sem mencionar evidências de fracasso, aponta que o fato de não se falar abertamente sobre as questões das crianças em situação de inclusão pode levar a uma não-inclusão. Exemplifica com o caso de um menino que ficou um

\footnotetext{
${ }^{7}$ É importante constar aqui que são chamadas de evidências, uma vez que os indicadores de sucesso e fracasso não estão explícitos e são extraídos de cada estudo através da leitura atenta e do olhar da presente pesquisadora, atravessados pelos objetivos desta pesquisa.
} 
ano num determinado grupo e passou despercebido: sem que o grupo o reconhecesse como alguém que fizesse parte do mesmo. O que a levou a constatar tal indício foi o fato de que as crianças não se importavam com o que ele fazia assim como não cobravam dele que seguisse as regras consentidas no grupo.

Mas por que as crianças (e funcionários) não questionavam o que ele fazia? Por que ele podia fazer tudo diferente? (...) O que fica sugerido é que Guilherme não existia no grupo. (...) Com relação às crianças, isso acontecia, muito provavelmente, porque as dificuldades do Guilherme não eram nomeadas, e, portanto, "não existiam" (Sekkel, 2003, p. 115)

Entretanto, sua pesquisa aponta para alguns elementos que, de acordo com o que buscamos investigar, podem ser considerados indicadores de sucesso nos processos inclusivos. A autora entende as ações vinculadas ao cuidar, confiar e refletir como necessárias à construção de um coletivo na escola, que tenha como objetivo a educação para finalidades humanas. A partir da análise e discussão de alguns processos inclusivos dentro da Creche Oeste, pôde constatar que reuniões inter e multidisciplinares com os profissionais envolvidos com as crianças em questão juntamente com a equipe pedagógica da creche, favorece uma troca de conhecimentos e experiências valiosas para a condução dos processos e, portanto, para o alcance do êxito da inclusão.

Nessas conversas todos podem se colocar e ajudar a pensar os problemas levantados; não são só os especialistas que falam e orientam as ações propostas. Considero que a participação dos profissionais de outras áreas é de fundamental importância no processo de inclusão. Sem eles, os especialistas não têm acesso a esse detalhamento que muitas vezes só pode ser evocado a partir de falas que ocorrem durante a própria conversa. (Sekkel, 2003, p. 107).

Apesar de não ser o seu objetivo, também pôde observar que a interação social entre pares carrega em si indicadores positivos para os processos inclusivos. A partir dos recortes relatados, pôde observar que alguns pequenos movimentos entre as crianças revelavam a verdadeira existência das crianças em situação de inclusão em seus grupos:

Esse movimento das outras crianças quererem experimentar o que a Bruna come e sentar na cadeira de rodas acontece muitas vezes. É um movimento para conhecer, se colocar no lugar do outro (Sekkel, 2003, p. 149). 


\section{E adiante complementa:}

(...) quando as crianças também são parceiras e sabem o porquê das coisas, então é possível ter um ambiente de relações que é cuidador. Claro que isso não tira a responsabilidade da supervisão dos adultos (...) mas alarga, amplia e garante esse olhar. E também incentiva nas crianças a participação e o respeito de serem ouvidas e levadas em consideração, o que representa nada mais, nada menos, que a educação para a cidadania (Sekkel, 2003, p. 153).

A partir dos desdobramentos de um dos casos apresentados, (e citado anteriormente), verificou que, no caso da creche, ter uma estagiária que atuasse junto à criança em questão ajudou-os a alcançarem o objetivo de trazê-la para o grupo, o que para a equipe da instituição significou um ponto de sucesso no processo desenvolvido.

Avaliamos conjuntamente que, se houvesse um educador com o Guilherme em alguns momentos planejados, isso já poderia provocar uma mudança. Foi assim que criamos a proposta de ter uma educadora três vezes por semana, durante duas horas (...) e o seu objetivo: trazer Guilherme para o grupo.. (...) Para Mariana trazer Guilherme para o grupo era necessário que ela mesma fizesse parte do grupo (Sekkel, 2003, pp. 110-117).

A partir de todas as evidências levantadas, Sekkel propõe que para trabalhar com a inclusão escolar é necessário criar um ambiente inclusivo, a partir de princípios democráticos, os quais precisam ser discutidos e consentidos, na situação concreta, ao longo do processo de (re)construção do projeto institucional. Apurou que é somente a partir da abertura à experiência e às ações emergentes da mesma que a educação pode caminhar na direção das necessidades do desenvolvimento humano, norteadas por princípios que dão sustentação aos objetivos educacionais para a construção de uma sociedade democrática. Afirma por fim, que para a superação das barreiras que concretizam a exclusão é essencial que haja a tomada de consciência de tudo aquilo que gera a exclusão em nossa sociedade, e da ameaça que ela representa para todos nós. Portanto, a inclusão deve ser pensada não apenas teoricamente, como também na prática, se houver a intenção de que ela produza mudanças efetivas.

Em relação à existência de um educador que atue junto à criança no ambiente escolar com objetivo de trazê-la para o grupo, de acordo com o que foi apontado positivamente por Sekkel (2003), Fráguas (2003) buscou compreender as mudanças na fala de uma criança com diagnóstico autístico e os efeitos subjetivos num processo 
de escolarização a partir da intervenção de um acompanhamento terapêutico dentro da escola. A autora (idem), utilizando-se dos referenciais psicanalíticos que fundamentam a proposta da Psicopatologia Fundamental, assinala que um sinal positivo em relação ao processo inclusivo foi a presença da At (Acompanhante terapêutica) na escola, capaz de estabelecer laço social com a criança em questão o que, de acordo com o método de investigação utilizado pela autora, promoveu uma mudança no funcionamento psíquico. Propõe que, para que haja as mudanças apontadas como significativas e, portanto, positivas para a criança e o seu processo de inclusão, são necessários aposta e olhar libidinal dirigidos a ela. A partir disso, ela passaria a ocupar para o Outro o lugar de um Ideal e de sujeito, o que nesse caso, só pôde ser alcançado a partir da existência da At, uma vez que a escola se posicionou como pouco preparada para implicar-se com o processo em questão.

De maneira sutil e sem levantar a possibilidade de fracasso na prática do processo inclusivo, a autora destaca que a escola se apresentou como não tendo condições de trabalhar com a criança, devido ao pouco preparo do professor para lidar com crianças com psicopatologias graves. Para isso, recorreram ao acompanhamento terapêutico, uma vez que com as demandas do grupo de crianças, o professor não podia dar uma atenção mais individualizada à criança, ficando isso à cargo do próprio At.

Apesar de esta situação não deixar evidente nenhuma referência ao fracasso do processo inclusivo, retomando o que aponta Sekkel (2003 e 2008) para que a inclusão possa acontecer é necessária a construção de um ambiente inclusivo, no qual haja "uma articulação coletiva e uma ação comprometida com o reconhecimento e busca da satisfação das necessidades de cada um a qual se inscreve no âmbito da construção de uma sociedade verdadeiramente humana, em que as pessoas possam se diferenciar e se desenvolver em busca de felicidade" (Sekkel, 2008, p. 32; grifos da autora), a escola não buscou encontrar soluções internamente de maneira coletiva, e alegou que o despreparo dos professores levou à busca de um recurso externo para lidar com a situação da inclusão. A atuação da At, uma ajuda externa a instituição, possibilitou uma modificação psíquica na criança, fazendo com que as outras crianças de seu grupo passassem a lhe dirigir a palavra, dando início ao estabelecimento de laço social.

Retomando as teses e dissertações que foram apresentadas, é possível reconhecer que alguns indicadores de sucesso aparecem com certa frequência nos 
diferentes estudos. Rahme (2010), Leodoro (2008) e Sekkel (2003) colocam a questão de que apenas os manuais e decretos não são suficientes para que a inclusão escolar aconteça, evidenciando aspectos de fracasso quando as instituições tentam fazer a inclusão somente com base nesses materiais. Para isso, deixam claro, como um possível indicador de sucesso, a necessidade de reflexão a respeito da prática educativa inclusiva que vem acontecendo nas escolas regulares, para que a partir disso a inclusão possa ser pensada e praticada de acordo com a realidade que se apresenta. Bastos (2003)e Prioste (2006) abordam a necessidade de existir um espaço de escuta e troca entre os professores com o objetivo de acolher angústias decorrentes do cotidiano escolar e de promover novas soluções para o dia a dia com as crianças em situação de inclusão. Anhão (2009) e Rahme (2010) constataram que a convivência entre pares traz contribuições significativas tanto para o desenvolvimento infantil dos protagonistas destas relações, quanto para a produção e o reconhecimento de subjetividades, deixando claro o indício de sucesso. Emilio (2004), Sekkel (2003) e Fráguas (2003) evidenciam a importância de dispositivos internos — trocas multi e interdisciplinares, implicação da família e acompanhamento terapêutico — nas instituições que favoreçam o trabalho com a inclusão, apontando tais medidas como um fator de sucesso.

De modo geral, os autores apresentam situações sobre os envolvidos nos processos inclusivos educacionais - educadores, alunos e famílias - e revelam a importância de as crianças com necessidades educacionais especiais pertencerem ao sistema regular de ensino. Processo que deve ser amparado não apenas pelos decretos e leis, mas pela elaboração de dispositivos internos e pelas constantes reflexões sobre a prática educativa cotidiana. Também são bastante mencionadas as contribuições da inclusão para o ganho qualitativo da criança quanto a seus recursos subjetivos.

As produções abordadas tendem a considerar o processo de inclusão escolar predominantemente por duas perspectivas: a primeira diz respeito aos ganhos qualitativos que a inclusão escolar pode representar para a criança do ponto de vista subjetivo, no qual fica patente a contribuição da especificidade da Psicanálise para o tema. A segunda diz respeito ao discurso dos professores e propõe uma crítica ao reducionismo da inclusão a um ganho cognitivo ou outro desempenho, muitas vezes referido pelos educadores como impossibilitado devido à condição patológica do aluno. Esta perspectiva concorda com contribuições para o debate acerca da inclusão escolar oriundas de abordagens diferentes da psicanalítica. Entretanto, não parece ser 
frequente que os autores da área articulem ganhos cognitivos ou de desenvolvimento (da comunicação, por exemplo) com os ganhos psíquicos e discursivos mencionados.

Se pensarmos em Educação no sentido mais amplo, de transmissão de marcas simbólicas como bem nos esclarece Lajonquière (2001, p. 56): “(..) marcas simbólicas - marcas de pertinência - que possibilitam usufruir um lugar, no campo da palavra e da linguagem, a partir do qual o desejo seja possível", não existe ser humano que não se beneficie com ela, uma vez que, dentro da escola na presença de outras crianças e profissionais atentos à singularidade, cria-se um terreno que oferece a possibilidade de construir laços ou enlaces sociais.

Kupfer (2001), ao citar Jerusalinsky (1997) afirma: quem frequenta a escola pode receber o carimbo de criança. Nas palavras do autor:

Porque escola é coisa de criança, no final das contas se esses meninos e meninas têm problemas mas estão na escola, seus atos viram artes. (...) são simplesmente meninos e meninas, seguramente o são porque vão à escola (Jerusalinsky, 1997, p. 91).

No entanto, como foi possível observar pelos estudos apresentados até o momento, há crianças que, por suas complexidades, pela severidade de seus comprometimentos ou por suas histórias familiares, podem não se beneficiar com o que a escola regular costuma oferecer. Elas enfrentam dificuldades reais para se adaptarem à turma regular. Por conta disso, faz-se necessário avaliar quais são as suas reais possibilidades a fim de analisar suas condições de acompanhar os processos de ensino e aprendizagem.

Nesse sentido, é importante ressaltarmos que a inclusão escolar, sobretudo de crianças autistas e psicóticas, não pode ser feita a qualquer preço, e cabe a nós psicanalistas e educadores - indagar se essas crianças têm as 'ferramentas' necessárias para usufruir daquilo que o convívio escolar deve proporcionar-lhes, enquanto gerador de laços sociais (Bastos, 2001, p. 49).

Kupfer (2001, p. 77) afirma que conviver com os outros é o que possibilita a construção do tecido do sujeito e, portanto, a sua constituição como sujeito. Se algo da história da criança revela um impedimento de estabelecer laço social, uma das possíveis formas de tratamento é buscar um reordenamento simbólico, levando-a à trama social, como por exemplo, às escolas. 
Tomando como exemplo o tratamento da psicose infantil, a autora, citando Albe e Magarián (1991), assinala a importância de se ter como norte o estabelecimento do laço social:

(...) Se, no entanto, esse resgate pode ser pensado, estruturalmente falando como impossível, devido à própria posição em que se encontra um psicótico frente ao discurso, encontram-se na literatura formas de fazer face ou mesmo de contornar essa impossibilidade. Se não há laço, pode haver, por outro lado, enlace, entendido justamente como uma forma de circulação social possível (Kupfer, 2001, p. 78).

Fazendo uma ponte entre o tratar e o educar, Kupfer segue discutindo os conceitos de laço e enlace e aponta para um questionamento feito pelas autoras a respeito do papel da escola na produção do laço social, no qual se justifica que se o laço social pode ser produzido dentro de instituições de tratamento como os hospitaisdia, nas escolas pode-se produzir o que elas chamam de enlaces, termo que se refere aos efeitos da circulação social.

No entanto, a prática que vem acontecendo com frequência atualmente, de incluir crianças com necessidades educacionais especiais em escolas regulares, não deixa de evidenciar divergências e se depara com impasses que levam a questionamentos sobre a condução e a validade de tal processo. Voltolini (2002), ao discutir sobre o discurso analítico e a inclusão, retoma a questão central do projeto social e se questiona a respeito do que tornou (ou torna) tais escolas tão refratárias a essas crianças. Faz um resgate histórico sobre a loucura, para refletir sobre a segregação e a partir de questões desenvolvidas por Foucault (1961), o autor apresenta duas constatações:

(...) uma a que ele [Foucault] dá o nome de experiência trágica da loucura e a segunda que ele chama de experiência crítica da loucura. Na primeira haveria espaço para a palavra do louco. Sua inclusão social estava alicerçada no fato de que sua palavra não era amputada da dimensão de verdade e seu ato era tomado como obra. Neste estado de coisas o louco podia circular nos espaços sociais porque sua circulação no discurso social não the prescrevia um lugar de exceção, de fora. A tragicidade de sua experiência não era feita de um material diferente da de todos. Mas foi com a modernidade, entretanto, que nasceu a experiência crítica da loucura. No cerne desta atitude estava: a exclusão da loucura do discurso social através do advento do predomínio da razão" (Voltolini, 2002, p. 2; grifos do autor).

É possível considerar que, ainda que haja grande campanha pela inclusão social e, consequentemente, pela inclusão escolar, existem resistentes obstáculos que 
inviabilizam a sua efetivação. Resquícios históricos e sociais, como já introduzimos no início deste capítulo e que aprofundaremos daqui por diante.

Diversas diretrizes políticas de reformas, norteadas pelos princípios da inclusão escolar no campo dos sistemas educacionais, têm sido anunciadas. Contudo, observa-se uma ausência de procedimentos de avaliação, que acabam por comprometer o processo de implementação das propostas.

Faltam indicadores para monitorar o processo, os que acenam com estatísticas promissoras muitas vezes não possuem dados confiáveis, e outras vezes não complementam seus estudos com descrições de quem é esse alunado e de como está sua situação educacional - ou, mais especificamente, se eles estão tendo acesso ao currículo, se estão socializando na direção desejável e se estão sendo socialmente aceitos na escola (Mendes, 2006, p. 399).

A partir do levantamento dos estudos sobre os processos inclusivos escolares, constatamos que dados implicam noções de sucesso na inclusão escolar têm sido pouco explorados, embora sua importância seja recorrentemente assinalada na literatura especializada. Dessa maneira, a presente pesquisa tem como objetivo tomar elementos discursivos para constituí-los como indicadores de sucesso da educação inclusiva que contribuam com a avaliação destes processos e, portanto, com a sua validade.

Tomaremos os registros feitos a partir das entrevistas realizadas com alguns educadores de uma escola particular de educação infantil de São Paulo que possuem entre seus alunos crianças em situação de inclusão. Serão também levados em conta os registros colhidos a partir de entrevistas realizadas em uma creche com o intuito de utilizar os dados obtidos para verificar a ocorrência de saturação do universo amostral da pesquisa (Fontanella, Ricas \& Turato, 2008). Pretendemos identificar o que permite considerar a inclusão escolar como bem-sucedida.

Tendo como pano de fundo a questão relativa ao sucesso da inclusão escolar, a dissertação está organizada em torno de 3 eixos: como a inclusão escolar é vista e promovida na atualidade, a Psicanálise e a educação inclusiva e, no terceiro e último, investigam-se dados referentes às entrevistas realizadas nas duas instituições de educação infantil.

Nesse sentido, o segundo capítulo procurará abordar como a educação inclusiva é vista hoje e quais são as posições tomadas pelos movimentos existentes: inclusão total e irrestrita (defendida pelo discurso sociológico) e a inclusão possível 
(defensável a partir de uma perspectiva psicanalítica). Através do breve histórico da inclusão até a atualidade, veremos que são discussões que culminam num grande e contínuo debate.

O terceiro capítulo abordará o tema da Psicanálise, da Educação e de suas relações com o indivíduo diferente. A partir das considerações acerca da prática inclusiva, retomaremos os efeitos da relação com o estranho familiar (Freud, 1919) e seus desdobramentos a respeito da segregação trabalhados na teoria lacaniana. Discutiremos também a questão das terminologias atribuídas aos alunos diretamente vinculados à educação inclusiva e a dificuldade de se encontrar termos que não segreguem e não classifiquem essas crianças.

O quarto capítulo enfocará as noções de sucesso e fracasso, bem como a introdução do que seria indicador e como ele tem sido utilizado no campo da Psicanálise - Instrumento IRDI - (Kupfer et al,, 2009), além de apresentar a analogia realizada para a elaboração dos indicadores de sucesso da inclusão escolar.

No capítulo cinco será apresentado o histórico e o lugar da escola de educação infantil, uma instituição assegurada pelas leis nacionais, diante da educação inclusiva, além de contextualizar a importância de realizar esta pesquisa na educação infantil. Abordaremos a escolha das instituições pesquisadas apontando para a questão ética envolvida e encerraremos o capítulo introduzindo o conceito de amostragem por saturação (Fontanella et al., 2008).

O sexto capítulo tratará do método de análise da pesquisa, a teoria lacaniana dos quatro discursos, e apresentará a maneira através da qual essa teoria vem sendo utilizada nas pesquisas com o tema da educação inclusiva.

O sétimo capítulo apresentará a análise das entrevistas com os educadores da escola de educação infantil e da creche. Será constituída uma narrativa de acontecimentos registrados durante a investigação seguida por uma análise fundamentada pela teoria lacaniana dos quatro discursos com o propósito de tomar elementos discursivos com indicadores de sucesso na inclusão escolar.

No oitavo capítulo encontra-se a discussão e os encaminhamentos dos dados obtidos através da pesquisa

O nono e último capítulo, das considerações finais, retoma as principais questões que nortearam essa pesquisa, localizando alcances e limites do trabalho desenvolvido. Busca-se abordar nesse tópico aspectos que indicam o não esgotamento do debate que envolve o tema inclusão. 


\section{2}

\section{Educação inclusiva: inclusão total e inclusão possível}

Para darmos início à apresentação das diferentes perspectivas teóricas que defendem a educação inclusiva, faz-se necessária uma introdução sobre as heranças histórico-culturais do paradigma da inclusão que atravessaram o tempo, carregando marcas que se fazem presentes até a atualidade.

\section{1. Inclusão escolar, heranças históricas e impasses contemporâneos}

As problemáticas que se desdobram do paradigma da inclusão e, consequentemente, da inclusão escolar, embora atuais, não dizem respeito unicamente aos movimentos desencadeados em torno das questões sobre a escolarização dos alunos antes chamados "deficientes" e, posteriormente, denominados "com necessidades educacionais especiais", principalmente a partir do final no século 20.

No que se refere à deficiência, no século 16 começaram a surgir novas ideias quanto à organicidade de sua natureza - passou a ser considerada produto de infortúnios naturais - e a ser tratada através dos métodos da incipiente medicina (Aranha, 2001). A relação da sociedade com a pessoa deficiente caracterizou-se por iniciativas de institucionalização total, de tratamentos médicos e pelas buscas por estratégias de ensino.

Foi uma fase se segregação, justificada pela crença de que a pessoa diferente seria mais bem cuidada e protegida se confinada em ambiente separado, também para proteger a sociedade dos "anormais" (Mendes, 2006, p. 387).

No início do século 19, houve uma formalização das instituições segregadoras que se encarregavam da retirada das pessoas com deficiência de suas comunidades de origem para enviarem-nas às instituições residenciais separadas ou às escolas especiais, quase sempre longe de suas famílias. Nessa mesma época, além das escolas especiais, também surgiram as classes especiais nas escolas regulares, para onde eram encaminhados os alunos difíceis (Mendes, 2006).

Em meados do século 20 as escolas especiais já se constituíam como um sistema paralelo as escolas regulares. Contudo, muitos autores passaram a publicar estudos que tratavam das instituições e de seus efeitos nos indivíduos ali internados. 
Muitos deles apontavam para uma inadequação do sistema, além da ineficiência para realizar aquilo que se propunham a fazer: "favorecer a recuperação das pessoas para a vida em sociedade" (Aranha, 2001, p. 9). Os movimentos sociais na luta pelos direitos humanos, que tomaram força na década de 1960, conscientizaram a sociedade a respeito dos prejuízos da segregação.

Esses questionamentos instauraram, a partir dos anos 1950, movimentos por reformas nas instituições destinadas à educação da criança deficiente (ou, diferente). No caso da Educação, movimentos como a normalização, o mainstreaming ${ }^{8}$ e a integração, visavam à introdução de percursos de escolarização tidos como menos restritivos.

Tal contexto contribuiu para o movimento de desinstitucionalização - de questionamento das estruturas asilares destinadas às pessoas consideradas deficientes ou doentes mentais - inicialmente difundido na Itália pelas ideias de Franco Baságlia $(1924-1980)^{9}$. Baseado na ideologia da normalização (princípios norteadores do movimento de integração social, paradigma que viria aparecer mais tarde), a convergência de esforços pregava a saída das pessoas das instituições aproximando-as ao máximo do que fosse considerado o estilo de vida normal em sociedade. Gradativamente, foi-se configurando uma nova proposta: o conceito de integração e, consequentemente, o de integração escolar, baseados no argumento de que todas as pessoas com deficiência teriam o direito inalienável de participar de todos os programas e propostas cotidianas que eram acessíveis para toda a sociedade. Baseada no princípio de normalização:

(..) a integração visava introduzir a pessoa com deficiência na sociedade, ajudando-a a adquirir as condições e os padrões da vida cotidiana e mais próximo do normal, quanto possível. (Aranha, 2001, p. 15; grifos da autora).

\footnotetext{
${ }^{8}$ De acordo com Mendes (2006) o termo mainstreaming (fluxo principal ou tendência principal) foi traduzido no Brasil como integração, mas é importante levar em conta que na literatura inglesa os conceitos são diferentes.

${ }^{9}$ Franco Basaglia foi médico e psiquiatra e o precursor do movimento de reforma psiquiátrica italiano conhecido como Psiquiatria Democrática. Nasceu no ano de 1924 em Veneza, Itália, e faleceu em 1980. No ano de 1961, quando assumiu a direção do Hospital Psiquiátrico de Gorizia iniciou mudanças com o objetivo de transformá-lo em uma comunidade terapêutica. A partir de 1970, quando foi nomeado diretor do Hospital Provincial na cidade de Trieste, iniciou o processo de fechamento daquele hospital psiquiátrico, e promoveu a substituição do tratamento hospitalar e manicomial por uma rede territorial de atendimento.
} 
As práticas integradoras educacionais significavam que as crianças, jovens e adultos poderiam transitar dos serviços segregadores em direção aos serviços menos segregadores - como as escolas regulares — além de apresentarem argumentos racionais baseados nos benefícios tanto para os alunos deficientes quanto para os colegas sem deficiência. Os deficientes poderiam participar de ambientes de aprendizagem desafiadores, ter oportunidades de conviver e aprender com alunos com competências diferentes, além de terem a chance de viver em um ambiente mais normalizante e realista. Já os alunos sem deficiência teriam a possibilidade de aprender a conviver e aceitar as diferenças.

O contexto econômico da época - a crise mundial do petróleo, por volta de 1960 e 1970 - também contribuiu para o estabelecimento da filosofia da integração e normalização. A crise que levou à escassez de recursos, aliada ao custo elevado dos programas segregados, permitiu a convergência de interesses em direção à integração dos deficientes nos serviços regulares da sociedade.

Entretanto, a integração escolar não era entendida (e nem aplicada) como uma questão de tudo ou nada, e sim como um processo de diversos níveis e condições, através dos quais o sistema educacional proveria os meios mais adequados para atender às necessidades de determinados alunos e em determinados contextos (Mendes, 2006).

Segundo Mrech (2001), os países nórdicos são considerados os pioneiros do movimento pela integração juntamente com os Estados Unidos. Suas experiências tiveram desdobramentos importantes, com repercussão mundial, e a disseminação de saberes e práticas que foram, posteriormente, formalizadas principalmente no que tange ao campo da Educação.

Embora fosse nítido o movimento cada vez maior em aproximar as pessoas deficientes da comunidade, o objetivo principal da mudança centrava-se ainda, essencialmente, no próprio indivíduo. Ele teria que, através dos recursos oferecidos, se esforçar para se aproximar o quanto possível da normalidade, assemelhando-se ao não deficiente.

O movimento pela inclusão escolar de crianças e jovens com necessidades educacionais especiais surgiu primeiramente nos Estados Unidos, que devido a intensa capacidade de penetração mundial (cultural e econômica), pôde ser disseminado ao longo da década de 1990. 
Segundo Mendes (2006), pesquisadores norte-americanos reconheceram que o termo inclusão associado à ideia de colocação dos alunos com difículdades prioritariamente nas salas de aula comuns das escolas regulares, veio substituir o até então empregado termo integração.

Um dos marcos mundiais em direção a educação inclusiva, foi a Conferência Mundial sobre Necessidades Educacionais Especiais: acesso e qualidade, promovida pelo governo da Espanha e ocorrida em 1994. Nesta conferência elaborou-se a Declaração de Salamanca, considerada um dos mais importantes difusores da filosofia da educação inclusiva, que pauta a educação para todos sob a denominação de educação inclusiva.

Nós congregamos todos os governos e demandamos que eles: (...) se tornarem aptos a incluírem todas as crianças, independente de suas diferenças ou dificuldades individuais. Adotem o princípio da educação inclusiva em forma de lei ou de política, matriculando todas as crianças em escolas regulares, a menos que existam fortes razões para agir de outra forma (Brasil, 1997, p. 2).

No contexto mundial, o princípio da inclusão tornou-se uma proposta de aplicação no campo da Educação, que implicou na elaboração de um processo de duas vias, no qual as pessoas excluídas e a sociedade buscariam juntas efetivar o equilíbrio das oportunidades para todos. Esse princípio teve como base o conceito de inclusão social, o qual Sassaki (1997) introduz como:

(...) um processo bilateral no qual as pessoas, ainda excluídas, e a sociedade buscam em parceria, equacionar problemas, decidir sobre soluções e efetivar a equiparação de oportunidades para todos (Sassaki, 1997, p. 41).

Diferentemente do conceito de integração, o paradigma da inclusão trouxe um novo olhar para a inclusão das diferenças, centrando os esforços para além do indivíduo e investindo em criações, adaptações e condições que garantissem a acessibilidade e a participação de todos na vida comunitária. O acento desse novo princípio estava sobre a modificação da sociedade, compreendendo que é ela quem deve ser capaz de atender às necessidades de seus membros.

Dessa maneira, a educação inclusiva passou a configurar-se como parte integrante e essencial do processo de desenvolvimento de uma sociedade democrática. Embora o paradigma da inclusão tenha sido bastante difundido a partir do final do século 20, houve uma fase de transição entre a integração e a inclusão bastante 
importante, possibilitando inclusive uma co-existência necessária para que a integração pudesse vir a esmaecer-se e a inclusão pudesse, enfim, prevalecer. E nesse contexto, como aponta Sassaki (1997) houve uma inevitável confusão entre o emprego dos termos, falados e escritos com diversos sentidos por diferentes pessoas.

Esse histórico contribui para o esclarecimento do tema desta pesquisa, que se refere à investigação de indicadores de sucesso e fracasso da inclusão escolar na escola comum, tal como ela é apresentada atualmente nas políticas públicas: uma escola democrática, aberta a todos e, portanto, uma escola inclusiva.

Entretanto, um longo caminho histórico teve de ser percorrido até que se chegasse ao momento atual da difusão da cultura da educação inclusiva. Embora aprofundar-se no resgate histórico dos paradigmas e princípios da inclusão não seja o objetivo desta pesquisa, fez-se necessário uma contextualização a fim de situar as atuais perspectivas conceituais sobre a inclusão e de que maneira elas têm se apresentado nos campos da Psicanálise e da Educação nos dias de hoje.

É notório que com a prevalência do termo — ou paradigma — inclusão, algumas divergências a respeito da sua prática começaram a surgir e a enriquecer os impasses que se apresenta(va)m diante da educação inclusiva. Há os que defendam que a inclusão deve ser total e irrestrita e há os que defendam que ela deve ser considerada de acordo com cada caso, levando em conta as particularidades do indivíduo em questão. Tal discussão acaba por direcionar o tema para uma espécie de dicotomia entre duas diferentes perspectivas atuais: a que parte de uma visão sociológica do tema e defende a inclusão de todos e a que parte de uma visão psicanalítica e defende a inclusão possível.

Longe de tentar recobrir ambas perspectivas, o que nos distanciaria - e muito — do objetivo desta pesquisa, faremos um recorte sobre cada uma das posições acima citadas, com o intuito de contextualizar o momento atual da inclusão escolar.

\subsection{Uma perspectiva sociológica da inclusão.}

Em paralelo ao surgimento de um contexto histórico mundial que passou a reforçar cada vez mais a cultura da educação inclusiva, mantém-se ainda a dicotomia de perspectivas sobre as maneiras de se conceber as diretrizes de uma política de inclusão escolar nos sistemas educacionais, que no Brasil, teve início no final dos anos 90 e persiste até a atualidade. 
A perspectiva que defende a posição de "a todos incluir", parte de uma compreensão político-sociológica da inclusão. Parte das leis, diretrizes e declarações que foram estabelecidas nacional e/ou mundialmente e passa a criar e estabelecer métodos e práticas que favoreçam uma educação de qualidade para todos. Apesar do indiscutível desafio atual de conseguir que todos os alunos, independente de suas condições (sócio-econômicas, culturais, familiares e outras) e características, consigam sucesso em sua aprendizagem, inúmeras iniciativas de políticas públicas e intenções diversas vêm desenvolvendo investigações favoráveis de sucesso da aprendizagem em sala de aula, estudando novas formas de organização da escola além de estratégias capazes de implicar uma real transformação das suas concepções e de suas práticas (Costa, 1998, p. 9).

Ainscow (1998) aponta para a mudança de paradigmas referentes à inclusão desde a conferência ocorrida na cidade de Jomtien, em1990, como um esforço para se atingir uma educação para todos, acompanhado de movimentos que visam a educação inclusiva, cujo objetivo consiste em reestruturar as escolas, tornando-as possíveis às necessidades de todas as crianças. $\mathrm{O}$ autor ainda afirma que os que são considerados tendo necessidades educativas especiais passam a ser reconhecidos como um estímulo que promove estratégias destinadas a criar um ambiente mais rico para todos.

Para resolver os problemas que dizem respeito às formas de organização das escolas e das salas de aula, de modo que todas as crianças e jovens obtenham sucesso na aprendizagem, o autor propõe algumas formas possíveis de se avançar nesse campo. Entre elas encontramos a valorização profissional dos professores e o aperfeiçoamento das escolas. Parece que esse princípio proposto por Ainscow (1998) encontra eco no que propõe Mantoan $(2002,2006)$ a repeito da educação de qualidade para todos. Ambos defendem que a viabilidade da inclusão (que deve ser encarada como uma consequência do ensino de qualidade) só pode ocorrer através da transformação geral das escolas, visando atender aos princípios deste novo paradigma educacional. Para tanto, oferecem diversos meios e ações que devem ser adotados pelas escolas para que o princípio por eles defendido seja, enfim, cumprido.

Mantoan (2002) defende a ideia de que a inclusão não prevê a utilização de métodos e técnicas de ensino específicas para as diferentes deficiências e/ou necesidades específicas. O que a inclusão prevê é que os alunos aprendam até o limite em que conseguem chegar, caso o ensino que recebam seja de qualidade. A autora ainda aponta que a inclusão e, portanto, a educação de qualidade para todos, implica 
em mudanças que envolvem as condições relativas à adminstração e aos papéis desempenhados pelos membros da organização escolar.

$\mathrm{Na}$ mesma linha de pensamento, Ainscow (1998, p.16) também elenca algumas sugestões necessárias para o alcance da educação inclusiva, dentre elas o apoio e a valorização profissional dos professores, bem como o trabalho em conjunto que forneça aos professores a possibilidade de experenciarem e compartilharem diferentes formas de ação.

Vemos que os autores aqui citados ilustram, ainda que de maneira abreviada, uma amostra dos que defendem a perspectiva sociológica, mas já é possível identificar através de seus escritos, que eles indicam e fornecem estratégias, meios e sugestões valiosas sobre como viabilizar o trabalho com a inclusão escolar. Cercam de todos os lados as falhas que possam, eventualmente, trazer à tona qualquer posssibilidade de fracasso na educação de qualidade. Pode-se dizer que seus discursos partem de um lugar no qual, com os métodos à mão, espera-se que o trabalho com a inclusão ocorra.

Ambos autores oferecem modos de realizar a inclusão. Partem do que Lacan (1969) denominou como o Discurso do Mestre, que apenas quer que as coisas funcionem a partir dos métodos coletados e apresentados. Estratégias estas eficazes, que não permitem furos e restos, uma vez que todos estão cobertos, protegidos e atendidos em seu máximo: educadores, alunos e instituições.

Para que todas essas propostas sejam atendidas, aquilo que diz respeito às singularidades e particularidades de cada criança tem de ficar elidido do planejamento. Afinal, é uma perspectiva que se prepara para o todo (aquilo que é geral) e não exatamente para todos (que pode levar em conta as particularidades de todos os envolvidos). Nas palavras de Voltolini (2005):

Esse é mesmo o lema de qualquer movimento pró-inclusão, já que parte da constatação da desigualdade de direitos e do acesso na distribuição dos bens da cidade. E nesse sentido pretende quitar o que estiver em débito, ir até o fim, fazer-se todo (Voltolini, 2005, p. 154).

Guardaremos, por ora, essa apresentação da perspectiva sociológica, e daremos espaço para introduzir a perspectiva psicanalítica que, em outra direção, traz uma diferente possibilidade para a compreensão do trabalho com a inclusão escolar. 


\subsection{Uma perspectiva psicanalítica da inclusão.}

$\mathrm{Na}$ perspectiva psicanalítica também encontramos diversas pesquisas a respeito do tema inclusão. Debruçadas sobre os campos da Psicanálise e da Educação, elas vêm apresentando inúmeros impasses sobre os processos inclusivos que vêm ocorrendo nas escolas comuns, quando estas apóiam-se apenas nas leis e diretrizes como garantia de sucesso do movimento pró-inclusão.

Discute-se que a concepção de que a inclusão possa ser construída a partir de manuais, como um imperativo a ser cumprido, extrai do debate as dimensões de invenção e criatividade (autoria) da prática profissional, pois reduz a possibilidade de alargar os limites da escola em relação ao encontro dos que são diferentes. Alguns autores apresentados na introdução deste trabalho colocam a questão de que apenas manuais e decretos não são suficientes para que a inclusão escolar aconteça. Para isso, deixam claro, como uma das possibilidades da inclusão, a necessidade de reflexão a respeito da prática educativa inclusiva para que, a partir disso, a inclusão possa ser pensada e praticada de acordo com a realidade que se apresenta. Isso se aproxima do que é ressaltado por Kupfer e Petri (2000) ao afirmarem que para uma escola tornarse inclusiva é necessário muito mais do que uma reformulação de espaço físico, de conteúdo programático ou de ritmos de aprendizagem, ou uma maior preparação do professor.

É comum ouvirmos dos educadores que lidam diretamente com crianças que estão em situação de inclusão nas escolas regulares, uma queixa frequente sobre como trabalhar com crianças com problemas graves ou como trabalhar se a escola não oferece suporte necessário para tanto. Queixas que revelam um sintoma social em busca de respostas sobre "modos de fazer" a inclusão. Tal conjuntura pode, muitas vezes, prender o educador no lugar de queixoso e impotente frente à falta de recursos disponibilizados para a condução da inclusão. Condição que contribui para a paralisação dos processos inclusivos daquelas crianças que se encontram diante do próprio educador. Frente ao "modelo ideal", fornecido pelos modos de se trabalhar a inclusão, há o desaparecimento daquele a quem a escola se dirige: a própria criança, o indivíduo singular.

Em busca das respostas sobre como fazer e dos manuais que lhes ensinem o melhor caminho ou a melhor intervenção para com esses alunos, os educadores estão nada mais, nada menos do que indo em busca do ideal: o ideal de educar, o ideal de 
incluir. Segundo Voltolini (2011), no hábito da idealização, estamos fadados a pensar a escola em termos ideais, esquecendo o que ela é em termos reais. É provável que a concepção de "escola ideal" modelada para "orientar" enquanto o melhor caminho a ser seguido no quesito da educação inclusiva, tenha como decorrência o seu inverso: uma provável "desorientação".

Quando falamos de ideal, podemos retomar o que bem nos apresentou Freud (1914) em "Sobre o narcisismo: uma introdução" a respeito da teoria da libido e a formação do ideal necessário para a condição da repressão. Nesse contexto, Freud definiu o ideal do Eu como “o ego infantil, possuído de toda a perfeição e valor" (Freud, 1914, p. 100) é aquilo em direção a que surge o narcisismo do sujeito. O Eu, portanto, se constitui como tal em face desta imagem de perfeição e completude, dirigindo o amor, desfrutado na infância, a si mesmo. Ao não querer se privar da perfeição narcísica, projeta diante de si o seu ideal, como substituto do narcisismo perdido. Freud também deixa claro que o ideal do $E u$ desvenda um importante panorama para compreendermos a constituição dos grupos, pois além do seu aspecto individual, esse ideal tem seu aspecto social; constituindo também o ideal comum de uma família, uma classe ou uma nação.

Tal formulação nos permite uma analogia entre o ideal do $E u$ freudiano e o ideal de Inclusão contemporâneo. Ambos em busca de uma perfeição que se acredita ter existido, mas que se apresenta na impossibilidade de ser alcançada.

Isso não significa que a escola, na busca de encontrar o melhor meio de trabalhar com a inclusão, não deva manter alguns objetivos. Ao contrário, eles trazem perspectiva de planos e de intenções. No entanto, ter objetivos é diferente de tomá-los como ideal, como a perspectiva real. Nesse caso, a inclusão escolar como ideal apresenta-se como algo que tem a ver com a idéia de perfeição.

Retomando o ponto de vista freudiano (1921, 1930), não há pacto simbólico sem a renúncia pulsional de tratar o outro como objeto. Portanto, podemos considerar que somos capazes de acolher o outro quando ele carrega alguma semelhança, fazendo-nos considerá-lo semelhante. Todavia, Freud (1930) observa que o movimento de agregar, na condição de semelhante implica, automaticamente, na exclusão dos diferentes.

Essa ideia é reafirmada por Lacan (1969/1970), ao ressaltar que a fraternidade surge de um ato de segregação. Se tomarmos como verdadeira tal premissa, é possível constatar que a formação de um grupo se dá a partir da identificação com um 
elemento comum. Portanto, essa identificação acaba por definir as posições de quem se encontra dentro e quem se encontra fora do agrupamento alcançado - aqueles que se identificam e os que não se identificam.

Essas reflexões reforçam a observação feita por Lacan (1969/1970) sobre a quantidade de energia que investimos na relação com o outro para promover a fraternidade. Esse grau dispendido constitui-se como uma evidência do quanto não estamos, de início, preparados para essa situação. Portanto, seria importante reconhecer que as exigências da cultura impostas ao sujeito podem, a princípio, promover o seu pertencimento ao coletivo, mas não garantem que sua relação com os outros homens se faça de uma condição de semelhança.

É possível compreender que a formação de grupos se dá a partir da identificação dos sujeitos com um elemento comum, contudo, isso implica um número restrito de sujeitos, uma vez que nem todos tendem a se identificar com o mesmo elemento (o que por si só já marca as diferenças individuais). Para Voltolini (2004a) a tentativa de igualar os sujeitos e evitar a segregação para que componham um grupo — visão dos que, no campo da educação especial, defendem a inclusão total - acaba sendo um movimento repetitivo e incessante, dada a impossibilidade de se formar um grupo sem que permaneçam elementos do lado de fora:

Não existe um grupo que inclua a todos, na medida em que um grupo só se constitui quando marca uma diferença com aquilo que não pertencerá ao grupo. (...) Ou seja, não há como agregar sem segregar. Isto torna qualquer idéia de política inclusiva, uma vez que seu princípio é agregar quem está segregado, um movimento impossível dado seu caráter de infinitude (Voltolini, 2004a, p. 99).

Em seu seminário anual de 1969/1970, sobre o avesso da psicanálise, Lacan formulou a teoria dos quatro discursos ${ }^{10}$. Lacan retoma a consideração feita por Freud $(1925,1937)$ a respeito das três profissões consideradas por ele como impossíveis: governar, educar e analisar. Esses três ofícios declarados como impossíveis representam na teoria lacaniana diferentes maneiras de se estabelecer laço social. Diferentes maneiras de tentar contornar o impossível.

Dessa forma é possível pensar que os laços sociais que os discursos, segundo a teoria lacaniana, tentam articular são momentâneos, instáveis e incapazes de amarrar todo o real presente. As modalidades de discurso e, portanto, de estabelecer laço,

\footnotetext{
${ }^{10}$ No capítulo 5 essa teoria será melhor apresentada e aprofundada.
} 
trazem consigo algo do real. No entanto, ao escolher o universo simbólico, o homem renuncia a possibilidade de acesso ao real, o que implica em uma inevitável perda, algo impossível de ser totalmente representado. Havendo uma perda, haverá sempre um mal-estar. Uma falta que denuncia a impossibilidade de algo tornar-se total e de ser completamente recoberto. Perfeito e sem falhas.

Sobre isso Voltolini (2005, p. 155) bem nos lembra a importância de que "a inclusão tenha um lado terminável e outro interminável. Ou seja, que ela tenha um resto do qual não se possa evadir".

Até aqui temos a ideia de que ir em busca do ideal pode levar ao fracasso. Seja ele do encontro com o nosso ideal enquanto sujeito, da escola enquanto perfeita, da inclusão enquanto total. Temos, portanto, que o ideal de "a todos incluir" é impossível pois ele nada mais é do que a recusa do resto. Ou seja, para evitar o fracasso, é preciso não prender-se nas ações idealizadas. E quanto a isso, novamente, Voltolini (2011) nos alerta:

Enfim, se não nos acautelarmos com a pregnância de nosso ideal não podemos senão sucumbir numa ação que será sempre lida como fracassada, que é o resultado inevitável de quem espera mais de uma coisa do que ela efetivamente pode ser (Voltolini, 2011, p. 6).

O desafio colocado por esta perspectiva é o de que mais do que transformações no ambiente e formações sobre como realizar o trabalho com a inclusão, o sistema escolar precisa sustentar, acompanhar e promover aquilo que uma criança necessita em sua singularidade. Isso significa reconhecer que dentro do todo existem as partes e ao cuidar de cada parte, algo do todo sempre irá sobrar. Essa perspectiva nos mostra que a pedagogia, amparada pela perspectiva sociológica, pode abrir as portas para outras áreas, sobretudo àquelas que se referem ao entendimento das crianças que, atualmente, estão tendo acesso às escolas regulares.

Portanto, dada a perspectiva psicanalítica que propõe que a inclusão total (ou de todos) é uma impossibilidade, ela nos parece ser uma ferramenta interessante para discutir a natureza das diferentes ocorrências da inclusão, dentre elas os indicadores de sucesso, o que esse trabalho se propõe fazer. 


\section{Psicanálise, Educação e a tentativa de entender a diferença}

Antes de adentrarmos no tema que envolve a Psicanálise, a educação inclusiva e os indicadores propriamente ditos, é preciso retomar algumas das primeiras ideias psicanalíticas articuladas por Freud $(1919,1921,1923,1930)$ e posteriormente por Lacan $(1945,1969 / 1970)$ a respeito do laço social, da segregação e da maneira como os indivíduos lidam com o estranho, a maneira pela qual os indivíduos se relacionam com aqueles que são considerados diferentes.

Faremos uma explanação sobre as contribuições da Psicanálise para o entendimento da diferença, seguida pela discussão sobre como a questão da diferença aparece na atualidade escolar para chegarmos, enfim, a mais uma das questões que permeiam o tema da inclusão: é possível nomear a diferença?

\subsection{Contribuições da Psicanálise para o entendimento da diferença.}

É importante tomar aqui as considerações acerca da origem do conceito de inclusão que se baseia na prática da exclusão e da segregação. Todos os processos, independente dos termos utilizados, integração, normalização, inclusão, são atravessados pelos efeitos da relação com o outro estranho e o que esse 'estrangeiro' pode provocar.

A presença da estranheza nas relações entre os seres humanos foi um tema ricamente discutido na obra freudiana. Investido nessa reflexão e em seus efeitos para a civilização, Freud mostrou-se atento aos aspectos decorrentes dessa relação, de que os estranhamentos não ocorrem pelo simples desconhecimento intelectual sobre o outro e sim por mecanismos inconscientes recalcados. Alguns de seus textos nos ajudam a elucidar os mecanismos pelos quais os seres humanos procuram excluir a diferença. Em $O$ estranho (Freud, 1919) abordou os efeitos provocados pela estranheza na relação com o outro; em Psicologia de grupo e análise do ego (Freud, 1921) discutiu a relação com o diferente na constituição dos grupos; e em $O$ mal-estar na civilização (Freud, 1930) abordou as questões da segregação das pequenas diferenças, desencadeadas pelo narcisismo.

Em $O$ mal-estar na civilização (Freud, 1930) Freud sugere a discussão de que a 
exigência proveniente das concepções do cristianismo "Amarás a teu próximo como a ti mesmo" é o que funda a segregação da diferença. O mandamento de amar ao próximo implica na exclusão, na negação do amor ao "não próximo", que passa a ser visto como ameaçador à ordem dos que se unem pelo amor ao conhecido. Desse modo, a raiz narcísica do amor pressupõe que esse sentimento seja dirigido aos semelhantes: ama-se as características próprias que podem ser reconhecidas no outro, enquanto se rejeita o irreconhecível, seja no outro, seja um si mesmo.

Não meramente esse estranho é, em geral, indigno de meu amor; honestamente, tenho que confessar que ele possui mais direito a minha hostilidade e, até mesmo, meu ódio. Não parece apresentar o mais leve traço de amor por mim e não demonstra a mínima consideração para comigo. Se ele puder auferir uma vantagem qualquer, não hesitará em me prejudicar; tampouco pergunta a si mesmo se a vantagem assim obtida contém alguma proporção com a extensão do dano que causa a mim (Freud, 1930, p. 115).

Tal mandamento acaba exigindo do sujeito aquilo que é reafirmado pela pressão civilizatória: a renúncia e o pacto em prol da convivência. Do ponto de vista freudiano $(1921,1930)$ não há pacto simbólico sem a renúncia pulsional de tratar o outro como objeto. Portanto, podemos considerar que somos capazes de acolher o outro quando ele carrega alguma semelhança, fazendo-nos considerá-lo semelhante:

Nas antipatias e aversões indisfarçadas que as pessoas sentem por estranhos com que têm de tratar, podemos identificar a expressão do amor a si mesmo, do narcisismo. Esse amor a si mesmo trabalha para a preservação do indivíduo e comporta-se como se a ocorrência de qualquer divergência de suas linhas específicas de desenvolvimento envolvesse uma crítica delas e uma exigência de sua alteração. (...) Mas, quando um grupo se forma, a totalidade dessa intolerância se desvanece, temporária ou permanentemente, dentro do grupo. Enquanto uma formação de grupo persiste ou até onde ela se estende, os indivíduos do grupo comportam-se como se fossem uniformes, toleram as peculiaridades de seus outros membros, igualam-se a eles e não sentem aversão por eles (Freud, 1921, p. 113).

Todavia, a suposição de que o desconhecido é ameaçador faz com que os mecanismos de rejeição se antecipem, excluindo previamente a diferença para que não se corra o risco do desconfortável encontro com o imprevisível. Freud (1930) observa que o movimento de agregar, na condição de semelhante implica, automaticamente, na exclusão dos diferentes.

Já assinalamos anteriormente a idéia de Lacan (1969/1970), a respeito da segregação, concepção que defende que a formacão de um grupo se dá a partir da identificação com um elemento comum marcando, portanto, as posições de quem se encontra dentro e quem se encontra fora do agrupamento alcançado. 
Freud (1930) já havia ressaltado quais seriam as conseqüências dessa renúncia pulsional, nas quais se encontram três origens desencadeadoras do sofrimento - $\mathrm{o}$ próprio corpo, o mundo externo e a relação com os outros homens —, e é nesta última que encontramos a maior fonte de mal-estar de que se queixam os humanos, capaz de levar algumas pessoas ao isolamento voluntário:

Contra o sofrimento que pode advir dos relacionamentos humanos a defesa mais imediata é o isolamento voluntário, o manter-se à distância das outras pessoas" (Freud, 1930, p. 85).

O presente trabalho, contudo, não trata de qualquer fonte de sofrimento, mas especificamente daquelas que se referem às diferenças presentes nas relações humanas. Às diferenças significativas que marcam a exclusão, o medo e o desamparo decorrentes das relações sociais.

Em 1919, no texto $O$ estranho, Freud afirma que o encontro com o outro que é diferente provoca ao mesmo tempo desconforto e desejo de mantê-lo distante. Existe um perigo iminente para o narcisismo de cada um, assim como há também o risco do encontro com o que há de mais estranho em nós mesmos. O estranho é a categoria do assustador que remete ao que é conhecido e familiar. A reação de rejeição seria então a manifestação de algo familiar que se encontrava oculta devido ao recalcamento e que retorna com essa nova qualidade:

(...) pois esse estranho não é nada novo ou velho, porém algo que é familiar e há muito estabelecido na mente, e que somente se alienou desta através do processo da repressão. (...) como algo que deveria ter permanecido oculto mas veio à luz (Freud, 1919, p. 258).

Portanto, ao longo da história social, os sujeitos considerados diferentes, seja devido às deficiências seja por outras particularidades, acabaram por encarnar a figura do estranho, despertando nos outros o medo de a eles se igualarem. Os sentimentos decorrentes do encontro com o estranho podem gerar movimentos discriminatórios, derivados do preconceito.

Embora não seja o objetivo desta dissertação discorrer sobre o preconceito e suas manifestações, faz-se necessário situá-lo a fim de que se tenha um melhor entendimento a respeito das relações humanas e a diferença.

De acordo com Crochik (2006), apesar de o preconceito ser um fenômeno psicológico, o que leva o indivíduo a ser ou não preconceituoso está vinculado ao seu processo de socialização e, portanto, de civilização,. Ou seja, a manifestação do 
preconceito é individual, mas surge em decorrência do processo de socialização. Segundo o autor, a atitude preconceituosa pode estar ligada à falta de reflexão:

O agir sem reflexão, de forma aparentemente imediata perante alguém, marca o preconceito, que sendo, a priori, uma reação congelada, assemelha-se à reação de paralisia momentânea que temos frente a um perigo real ou imaginário (Crochik, 2006, p. 14; grifos do autor).

Retornando às investidas de Freud (1919) a respeito da relação com o estranho, sobre o preconceito é possível considerar que o medo despertado no encontro com o desconhecido é menos produto daquilo que não conhecemos, do que daquilo que não queremos (re)conhecer em nós mesmos através dos outros.

E mais adiante, Crochik (2006) afirma:

Mais do que as diferenças individuais, o que leva o indivíduo a desenvolver preconceitos, ou não, é a possibilidade de ter experiências e refletir sobre si mesmo e sobre os outros nas relações sociais, facilitadas ou dificultadas pelas diversas instâncias sociais, presentes no processo de socialização (Crochik, 2006, p. 16).

Em O Ego e o Id, de 1923, ao discorrer sobre o aparelho psíquico, Freud define que ele é formado por instâncias, às quais ele denominou: Ego (Eu), Id (Isso) e Superego (Supereu). Sendo o Eu uma parte do Isso intermediária entre ele e o mundo externo, sua tarefa é a de autopreservação, esforçando-se pela prevalência do prazer e a evitação do desprazer. Desse modo, o aumento do desprazer é enfrentado como um sinal de ansiedade e pode ser reconhecido pelo Eu como um perigo.

Segundo Freud (1923), o Eu se constitui através das identificações: primeiramente se identifica com o que lhe dá prazer e através da projeção mecanismo de defesa do $\mathrm{Eu}$ - atribui e desloca para o mundo externo aquilo que the causa desprazer. Assim, se aquilo que lhe causa desprazer está fora e pode ameaçá-lo, o Eu promove uma espécie de "ataque", sendo esse ataque um mecanismo de defesa do próprio Eu em função de sua autopreservação. Portanto, o mecanismo de projeção seria então, uma forma de afastar aquilo que é diferente, desconhecido e assutador uma vez que a tendência do ser humano é se identificar com o que lhe dá prazer, e que pode já ser (re)conhecido.

Dessa maneira, é notório que as tendências humanas ao preconceito derivam de mecanismos psíquicos demasiadamente primitivos, mas que só se manifestam como tal a partir do processo de civilização. Isso porque é na sociedade que se 
encontram as classificações e estratificações relativas ao objeto.

Contudo, não podemos deixar de ressaltar que o processo de constituição do sujeito passa inevitavelmente pelos mecanismos de identificação, o que Freud (1921) denominou como "a mais remota expressão de um laço social com outra pessoa". Desse modo, considerou serem três as formas pelas quais se estabelece a identificação: 1. constitui a forma original de laço emocional com um objeto; 2. desempenha um papel na origem do complexo de Édipo: o menino desenvolve uma catexia de objeto sexual diretamente com a mãe e, na passagem do complexo de Édipo, recalca o desejo incestuoso e identifica-se com o pai, tomando-o como modelo devido à idealização. O menino percebe, entretanto, que o pai se coloca em seu caminho em relação à mãe; sua identificação com o pai passa a ostentar um colorido hostil e, então, passa a identificar-se com o desejo de substituí-lo também em relação à mãe. A identificação, na verdade, é ambivalente desde o início; pode tornar-se manifestação de ternura com tanta facilidade quanto um desejo de manter distância de alguém; 3. surge devido à percepção de uma qualidade comum partilhada com alguma pessoa que não é objeto do instinto sexual, de maneira que essa identificação parcial pode representar o início de um novo laço: "desejo de colocar-se na mesma posição" (Freud, 1921, p. 117).

Para o indivíduo preconceituoso, como afirma Crochik (2006), o outro diferente é tomado como um objeto ameaçador que precisa ser afastado. O preconceito, então, estaria ligado a um mecanismo desenvolvido pelo indivíduo para poder se defender de ameaças imaginárias:

(...) assim é um falseamento da realidade, a qual o indivíduo foi impedido de enxergar e que contém elementos que ele gostaria de ter para si, mas se vê obrigado a não poder tê-los; quanto maior o desejo de se poder se identificar com a pessoa vitima do preconceito, mais este tem de ser fortalecido (Crochik, 2006, p. 19).

Na mesma linha de pensamento que Crochik (2006), Amaral (2002, p. 237) afirma que as ações e os comportamentos discriminatórios dirigidos a um alvo específico "pessoas ou grupos significativamente diferentes", acabam por concretizarse nas relações interpessoais mediadas pelos estereótipos produzidos pela cultura que cobram definições precisas através das suas mais variadas diligências: escola, família, meios de comunicação, e todas as demais instâncias sociais que, de certa forma, cumprem com o papel da educação. Estereótipos que funcionam como etiquetagens 
discriminatórias e, consequentemente, segregadoras:

Ou seja, a partir de mensagens transmitidas em relações anteriores e/ou advindas dos meios de comunicação, predefinimos: o outro é assim, sente assim, pensa assim, age assim... E esse "assim" é uma camisa-de-força com a qual envolvemos nosso interlocutor e, dialeticamente, a nós mesmos (Amaral, 2002, p. 237).

E finaliza sua reflexão afirmando que:

Não há lugar para surpresas num mundo pleno de estereotipia e, portanto, não há lugar para desafios (Amaral, 2002, p. 237).

O que temos até aqui é um quadro que nos ajuda a entender não apenas as relações humanas, como, principalmente, as dificuldades do ser humano de se relacionar com o outro que não se manifesta como um semelhante, independente da marca que o torna diferente.

Veremos agora, como essas manifestações, inerentes ao ser humano, têm se apresentado no contexto escolar.

\subsection{A diferença no contexto escolar}

Se tomarmos o campo da pedagogia, como um dos focos desta discussão, veremos que a ideia de segregação das diferenças também surge mascarada pelo conceito da normalidade. Canguilhem (1990) assinala que o conceito de norma é polêmico, uma vez que para a criação de uma norma pressupõe-se a existência do seu contrário, ou seja, de uma diferença, daquilo que não se encaixa e que, portanto, encontra-se fora do esperado. Nesse sentido, o autor acentua que a norma, ao ser criada, não apenas procura eliminar a diferença como também estabelece uma escolha, e destaca:

Com efeito, uma norma só é a possibilidade de uma referência quando foi instituída ou escolhida como expressão de uma preferência e como instrumento de uma vontade de substituir um estado de coisas insatisfatório por um estado de coisas satisfatório. (Canguilhem, 1990, p. 212).

Partindo dessa lógica, o normal e o anormal posicionam-se como opostos em uma relação na qual para a prevalência de um há, inevitavemente, a exclusão do outro.

Nas escolas é comum a classificação dos alunos como normais ou crianças ditas 
normais. Nessa utilização do termo, muitas vezes está implícito o desejo da eliminação da diferença, daquilo que não se encaixa nos padrões da normalidade, daquilo que não é o esperado como objetivos e metas a serem atingidas nas avaliações do âmbito da Educação. Todavia, nos dias atuais eliminar a diferença pela segregação não é mais uma atitude aceita pela sociedade. Ao contrário, defende-se o compromisso da educação para todos, inclusive para as crianças com necessidades educacionais especiais dentro do sistema regular de ensino, como determina a Declaração sobre princípios, políticas e práticas na área das necessidades educativas especiais (Brasil, 1997). Mas, muitas vezes, o que acaba ocorrendo é uma espécie de alargamento da margem de aceitação daquilo que pode ser considerado como normal, o que também não deixa de ser uma atitude a favor da eliminação da diferença.

Seguindo nessa direção, temos aquilo que Freud nos apresentou em Sobre o narcisismo: uma Introdução (1914) a respeito das ocorrências nas quais há uma espécie de apagamento do sujeito quando existe a tentativa de incluí-lo em uma única lógica. Sobre isso, Freud nos diz:

Se prestarmos atenção nas atitudes dos pais afetuosos para com os filhos, temos de reconhecer que ela é uma revivência e reprodução de seu próprio narcisismo, que de há muito abandonaram (...) eles se acham sob a compulsão de atribuir todas as perfeições ao filho - que uma observação sóbria não permitiria — e de ocultar e esquecer todas as deficiências dele (Freud, 1914, p. 97, grifos nossos).

De acordo com os pressupostos das últimas declarações sobre o direito à educação para todos, parece que, quanto mais a igualdade de direitos for praticada, mais próximos do ideal de educacão inclusiva estaremos. Entretanto, na busca pela igualdade há, consequentemente, o apagamento da diferença para enquadrá-la na lógica contemporânea e globalizante dos direitos sociais.

Em relação à defesa da inclusão escolar, Kupfer (2005) levanta uma questão importante que ocorre com frequência nas salas de aula. Fazendo referência a uma pesquisa realizada na França com os denominados professores inclusivos, constatouse que ora coloca-se o acento sobre a igualdade impondo regras comuns a todos os alunos e negando, portanto, a diferença, ora coloca-se o foco sobre a diferença permitindo que a criança que "sai da norma" possa ter vantagens em relação ao restante do grupo. Isso nos leva a pensar que ao falarmos sobre a diferença, inevitavelmente, irrompe a ideia de norma e de normalidade. 
Ao falar das diferentes diferenças, o que surge é a ideia de que há uma norma, e o distanciamento gradual dessa norma definirá o grau de diferença que um sujeito assumirá em relação a ela. Quanto mais distante da norma, mais diferente. A igualdade seria então equiparada à norma, e as diferentes diferenças consistiriam em desvios maiores ou menores da norma da igualdade (Kupfer, 2005, p. 20).

Mais adiante Kupfer se questiona a respeito da classificação da diferença como desvio da norma como sendo a única forma de lidar com a dicotomia: diferença e igualdade. Dessa maneira, propõe um diferente ponto de partida para estabelecer essa articulação, afirmando que a diferença não deve ser considerada um desvio da norma, mas é preciso levar em conta que ela surge da norma a partir da lei. Assim colocado, é possível pensar que a diferença nasce da norma e, portanto, da noção de igualdade. Essa afirmação nos leva a uma nova forma de encarar essa articulação, atravessada agora pelo olhar da Psicanálise, no qual se coloca o acento no que diz respeito ao coletivo e ao individual, ao universal e ao particular .

Lacan trouxe significativas contribuições para a questão do coletivo e do singular, principalmente ao trabalhar as articulações com a lingüística. As produções decorrentes de seus estudos foram fundamentais para a leitura sobre a coletividade e a relação entre os sujeitos mediada pela linguagem, a qual ele denominou por discursos, diferentes maneiras de estabelecer laço social (Lacan, 1969/1970). Sendo a linguagem a condição do humano, carrega em si a evidência — já anteriormente apontada por Freud (1921) ao afirmar a indissociabilidade entre o singular e o coletivo - , de que “o coletivo não é nada senão o sujeito do individual" (Lacan, 1945, p. 213). Ainda a respeito da coletividade, Lacan (1945) marca uma diferença com a generalidade, assinalando que:

(...) a coletividade já está integralmente representada na forma do sofisma, uma vez que se define como um grupo formado pelas relações recíprocas de um número definido de indivíduos, ao contrário da generalidade, que se define como uma classe que abrange abstratamente um número indefinido de indivíduos (Lacan, 1945, p. 212; grifos do autor).

Desse modo, o viés psicanalítico que vem contribuindo para a reflexão sobre o significante inclusão que impera no campo da educação especial, nos mostra portanto, que a segregação é inevitável. Os grupos só se formam em torno de uma marca comum e os que nela não se encaixam são automaticamente excluídos. Isso torna qualquer política inclusiva um movimento impossível e, ao mesmo tempo, incessante.

A busca de saídas possíveis que livrem a educação inclusiva das amarras que a 
prendem às impossibilidades é uma das respostas que se pretende encontrar através desta pesquisa, como veremos mais adiante.

Dando continuidade à incursão sobre as relações com o outro diferente, embarcaremos numa discussão sobre as possibilidades ou não se de se nomear a diferença.

\section{3 É possível nomear a diferença?}

Não podemos tratar do tema inclusão escolar sem abordar as terminologias e nomenclaturas que vêm sendo usadas para identificar as crianças que passam por processos inclusivos.

De acordo com o resgate histórico apresentado no capítulo 2, até o final do século 20, essas crianças, que hoje em dia frequentam as escolas regulares, eram chamadas de "deficientes", independente das características e comprometimentos que possuíssem. Contudo, novas terminologias passaram a ser utilizadas a partir do final da década de 70 .

A expressão "necessidades educacionais especiais" (special educational needs) foi introduzida pela primeira vez em 1978 na elaboração do Relatório Warnock no Reino Unido, resultante de um inquérito que investigou as condições educacionais das crianças "deficientes". O relatório traduziu uma nova forma de pensar a deficiência, sublinhando que deficiência não é condição de uma necessidade especial e, portanto, colocou o foco na preocupação com a inserção destas pessoas na sociedade, implicando a educação no encaminhamento das questões referentes à aprendizagem, questionando a presença do discurso médico nesse campo. Um dos objetivos da introdução do termo necessidades educacionais especiais foi o de reduzir o peso segregador das classificações.

Essa terminologia é muito usada nos dias de hoje, principalmente no discurso pedagógico, assim como afirma De Luca (2003):

Estamos nos referindo às crianças que atualmente são nomeadas pelo discurso pedagógico como 'crianças com necessidades educativas especiais' (...) que busca abrir uma nova perspectiva de direitos e condições de vida para aqueles que não se enquadravam nos parâmetros da normalidade (De Luca, 2003, p. 12).

No entanto, sabe-se que dentro do campo escolar muitas outras nomeações informais são usadas para se referir a tais crianças, tais como: alunos incluídos, casos 
de inclusão, alunos de inclusão. Todos eles decorrentes do termo introduzido no final da década de 1970. Apesar de o conceito de inclusão trazer consigo uma nova perspectiva sobre o olhar para a diferença, parece que a necessidade de classificá-la continua impermeável às novas propostas e paradigmas.

Segundo Voltolini (2004b):

Com efeito, se diz nas escolas: temos " $X$ " alunos incluidos. Quantos incluídos vocês têm? Na minha sala tenho um só! Um novo rótulo que serve para excluir, evidentemente. (Voltolini, 2004b, p. 8, grifos do autor)

A definição de crianças com necessidades educacionais especiais aponta para uma questão bastante importante em relação aos processos de inclusão escolar, uma vez que essas crianças apresentam uma extensa gama de características referentes às suas dificuldades, o que por si só já impediriam uma generalização de medidas para tratá-las como um grupo homogêneo. Essa classificação "pasteurizada" corre o risco de promover um grande "faz de conta" em relação aos processos de inclusão, quando não levam em consideração que cada sujeito carrega consigo suas marcas particulares, suas características próprias e sua singularidade. Parece que ao invés de inclusão, volta-se a empregar a integração a qual se presta a encobrir as desigualdades, "forjando um processo de normalizacão que, longe de respeitar as diferenças, torna-se um corolário do ideal humanista do 'todos somos iguais'." (Bastos, 2003, p. 18).

A expressão necessidades educacionais especiais introduzida em 1978 e reafirmada em 1994 através da Declaração de Salamanca acabou se tornando uma superetiquetagem, que condensou todos os casos, das mais variadas vulnerabilidades escolares em uma única terminologia, apontando somente para as necessidades sem levar em consideração o que é da ordem do desejo.

Voltolini (2004a) problematiza quais seriam, portanto, as necessidades educativas especiais de um sujeito. Isso porque, ao centrar o sujeito em questão em suas necessidades, automaticamente, estaria-se excluindo aquilo que é da ordem do desejo. Ao fazer referência ao seminário sobre a ética de Lacan, o autor aponta para as marcações feitas entre pensar a partir de uma ordem coletiva qualquer proveniente da ideia de razão e necessidade, ou a partir da ideia de desejo.

Os sistemas sociais nada querem, em geral, saber sobre o desejo, uma vez que se parte dele não se sabe nunca onde vai parar. As necessidades apresentam-se como mais administráveis, mais razoáveis. Não é casual que o termo apareça na categoria crianças 
com necessidades educativas especiais (Voltolini, 2004a, p. 95).

De acordo com as pesquisas realizadas pelo Laboratório de Estudos sobre o Preconceito, encontrou-se uma nova maneira de se referir às crianças que necessitam ajuda específica no âmbito escolar. Seus pesquisadores (Freler, 2010; Crochik, 2011) passaram a utilizar o termo "alunos em situação de inclusão", com o objetivo de movimentar a situação dos alunos excluídos.

Os alunos não são de inclusão indefinidamente, como popularmente são denominados, mas estão em uma situação que demanda trabalho para se modificar, deve ser um lugar de passagem (Freler, 2010, p. 329).

Apresentamos aqui algumas das terminologias que são utilizadas para classificar aqueles que estão na escola, ou até mesmo na sociedade, e que de algum modo apresentam suas diferenças. Terminologias que não deixam de ser eufemismos para classificar os que, anteriormente, eram chamados de "descapacitados", "deficientes" e que hoje em dia, são denominados como "portadores de necessidades educativas especiais". Contudo, parece que todas as tentativas de nomear os que carregam uma marca que os torna diferentes acabam caindo no mesmo lugar: o da segregação. Quanto mais se tenta nomear a diferença, mas ela se torna evidente e em lugar de destaque nas relações sociais.

Já apresentamos uma passagem pela perspectiva psicanalítica que nos apresentou as explicações sobre o que o ser humano faz para lidar com as diferenças. Então talvez caiba aqui uma importante questão: o que fazer com essa tentativa que insiste na direção do enquadramento da diferença?

Pelo que pudemos traçar até o momento, vemos que a dicotomia normal/anormal (ou até mesmo: normal/diferente) atravessa o cerne da inclusão. Podemos encontrar uma justificativa para que tal dicotomia acompanhe esse tema, quando Freud (1910), em $O$ sentido antitético das palavras primitivas, introduz a observação sobre a existência de um bom número de palavras com duas significacões, sendo uma significação o oposto da outra, o que ele denominou de palavras que apresentam significações antitéticas. Com base nos estudos de Karl Abel (1884), Freud cita algumas de suas reflexões:

Se sempre houvesse luz, não seríamos capazes de distinguir a luz da escuridão e, 
consequentemente, não seríamos capazes de ter nem o conceito de luz e nem palavra para ele (Freud, 1910, p. 163).

E mais adiante complementa:

De vez que o conceito de força não se podia formar exceto com um contrário de fraqueza, a palavra designado "forte" continha uma lembrança simultânea de "fraco", como coisa pelo meio da qual ele, de início, ganhou existência. Na realidade, esta palavra não designava nem "forte" e nem "fraco", mas a relação e a diferença entre os dois, que criou ambos igualmente (Freud, 1910, p. 163).

Portanto, se todas as palavras possuem duas significações opostas, devido à origem de sua existência (no caso, Freud se baseia nos exemplos da língua egípcia ${ }^{11}$ ), sempre que falamos sobre agregar, quando temos como princípio a inclusão, automaticamente, nos remetemos ao seu oposto, segregar.

Então, temos um movimento de alcance impossível, dado que na busca por encontrar uma palavra que defina a diferença, corremos o risco de torná-la mais evidente e cada vez mais segregadora.

Ou seja, a diferença existe e não pode ser negada, nem pelo movimento de igualar e nem pelo movimento de deixá-la de fora. Mas ela precisa ser levada em conta pelo que possui de singular. A diferença tem de ser reconhecida e respeitada ao invés de se tentar apagá-la.

Jerusalinsky (2012) complementa essa ideia da valorização do singular como uma saída possível, dado que nos encontramos num cenário dicotômico e, por natureza, segregador. Ele nos diz que:

Também não deve ser feito dos descapacitados uma única classe. Justamente se fazemos deles uma classe única, uniforme e padrão, caraterizada pela falta de capacidade, lhes estaremos negando uma singularidade na qual poderiam encontrar uma representação no discurso. Porque, justamente, a única representação que o sujeito pode ter de si é singular: ou a tem singular ou não a tem. (Jerusalinsky, 2012, p. 34).

A tentativa de traçar esse caminho foi a de situar, ainda que minimamente, algumas das características que acompanham o tema da inclusão escolar. Contudo,

\footnotetext{
${ }^{11}$ Para introduzir suas reflexões sobre as significações antitéticas das palavras, Freud baseiou-se em um trabalho de Karl Abel, publicado em 1884, no qual ele apresenta ensaios filológicos sobre as línguas antigas, entre elas a língua egípcia. Abel afirma que, "nessas palavras compostas, conceitos contraditórios se combinaram de modo inteiramente intencional (...) uma parte que teria tido a mesma significação só por si..." (Karl Abel, 1884, citado por Freud, 1910, p. 163).
} 
dado que o objetivo desta pesquisa é o de obter, através dos discursos de educadores, aspectos que indiquem o sucesso dos processos inclusivos vivenciados por seus respectivos alunos, foi imprescindível pedir aos entrevistados que contassem sobre o trabalho realizado com os alunos que eram considerados, pela instituição, crianças em situação de inclusão. Desse modo, seguindo o que propuseram os pesquisadores do Laboratório de Estudos sobre o Preconceito, usaremos o termo situação de inclusão quando nos referirmos às crianças apresentadas nos discursos coletados, como veremos nas análises ao longo desta pesquisa. 


\section{4}

\section{Indicadores de sucesso na educação inclusiva}

Para compreendermos o que seriam os indicadores de sucesso da inclusão escolar, hipótese levantada para o desenvolvimento desta pesquisa, é preciso introduzir a noção de sucesso tão utilizada nesse trabalho para, em seguida, apresentar o que são os indicadores e, finalmente, o que pretendemos atingir quando falamos sobre indicadores de sucesso na inclusão escolar.

\subsection{Sucesso e fracasso: que ideias são essas?}

Antes de adentrarmos nas questões que tangem as situações de sucesso da inclusão, faz-se necessário deixar claro o significado atribuído a este conceito no presente contexto.

Segundo o dicionário Houaiss da língua portuguesa, sucesso é definido como um substantivo masculino: 1. aquilo que sucede; acontecimento, fato, ocorrência $<0$ s sucessos da história $>$; 2. qualquer resultado de um negócio, de um empreendimento Ex.: $<$ bom sucesso $><$ mau sucesso $>$; 2.1. bom resultado; êxito, triunfo $<$ tentou sem sucesso conquistá-la>; 3. pessoa ou coisa vitoriosa, de grande popularidade (p. ex., livro, filme, peça teatral, autor, diretor, artista, intérprete, etc.). E encontramos fracasso definido como substantivo masculino: 1. som estrepitoso provocado pela queda ou destroçamento de algo; barulho; estrondo $<$ a casa desabou com um fracasso assustador $>$; 2. falta de êxito; malogro; derrota $<0$ empreendimento foi um fracasso $>$ $<$ os muito ambiciosos custam a aceitar o fracasso $>$.

Autores como Patto (2000) e Charlot (2000) abordam a questão de sucesso e fracasso no campo da Educação. Charlot (2000) debruçou-se sobre o tema do fracasso escolar com base na relação do aluno com o saber, a partir da qual o fracasso é compreendido como uma experiência que o aluno vive e interpreta, e este se tornou o seu objeto de estudo sobre o fracasso em termos das diferenças singulares entre o saber e a escola. Já Patto (2000) procurou isolar as raízes escolares do fracasso (os reprovados, fracassados, crianças de classes populares etc.) de suas condicionantes histórico-sociais ao investigar as práticas escolares (discursivas e não-discursivas). Parece que ambos procuraram focalizar suas investigações para além do sistema de ensino e das generalizações, levando em conta as experiências vividas por cada um 
dos alunos ditos "fracassados", considerados indivíduos singulares. Entretanto, os conceitos de fracasso por eles considerados, limitaram-se ao campo educacional, não ultrapassando os limites para a área da inclusão escolar. Não nos aprofundaremos aqui no tema do fracasso escolar, principalmente no que diz respeito às pesquisas dos autores acima citados, pois isso nos levaria a uma extensa e diferente discussão. Mas apresentar este tema nos serve para demonstrar que alguns autores se utilizam das noções de fracasso e sucesso em outros campos de investigação, o que nos autoriza a utilizá-los no presente trabalho.

Também podemos encontrar em Mannoni (2003) uma referência ao fracasso ${ }^{12}$ na Educação ao utilizar-se da experiência de Jean Itard, pedagogo que, face ao problema do retardamento mental, tenta impor sua própria concepção de mundo à criança e acaba encontrando o mal-entendido dessa comunicação:

Itard imagina que Victor vive no mundo da necessidade pura (...)Victor se encontra, assim, tomado como objeto de cuidados e curiosidade, para em seguida, tornar-se objeto de medidas reeducativas e, é aqui, mais exatamente, que vai criar-se um certo mal-entendido fundamental. Victor anda não está em condições de articular demanda. Isso parece angustiar o médico (...). Ao longo da experiência de Itard, encontramos (...) o fracasso na comunicação com o Outro (...). O que vemos ao nível da estrita observação? Um adulto desarvorado diante de uma criança que não articula demanda alguma. $\mathrm{O}$ adulto quereria, a partir dessa ausência de demanda, encontrar na criança um desejo. Mas parece que não há lugar para o reconhecimento do desejo em um adulto que se refere sem cessar à necessidade (Mannoni, 2003, p. 199).

Parece que na tentativa de adaptar a criança ao que se esperava e de ver seu método de ensino prosperar ao transmiti-lo a Victor, Itard exclui o que dizia respeito a sua singularidade, impedindo que dele pudesse emergir uma demanda, fadando suas tentativas de comunicação e, portanto, de educação ao fracasso.

O que Mannoni apresenta como sendo fracasso na educação: a referência irrestrita à necessidade será, talvez, o que mais se aproxima do conceito de fracasso e, portanto, oposto da noção que pretendemos utilizar nesta pesquisa. O sucesso na inclusão escolar seria: reconhecer a singularidade, permitir o inesperado e, partir

\footnotetext{
${ }^{12}$ Até o momento, ficou claro que o objetivo desta pesquisa é o de obter indícios de sucesso da inclusão escolar a partir dos relatos colhidos com as educadoras. Contudo, haja vista o que apresentamos no capítulo anterior sobre as ideias antitéticas, palavras que possuem duas significações opostas, podemos considerar que ao tomar uma das significações como objeto de estudo, estamos, automaticamente, abordando a outra significação. Nesse caso, precisamos levar em conta que, mesmo acompanhando a análise de Mannoni sobre o fracasso da educacão de Victor de Aveyron, podemos pensar sobre o que seria, então, o oposto dele: o sucesso.
} 
disso, reconhecer a criança como um sujeito às voltas com o desejo. Assim afirma Mannoni (1999)

O que conta é procurar, para além do deficiente, a palavra que o constitui como sujeito às voltas com o desejo (Mannoni, 1999, p. 196).

Não podemos deixar de notar que, na busca pela utilizacão das noções sucesso/fracasso, encontramos autores que deram ênfase ao fracasso como "coadjuvante" de seus objetos de estudo. É provável que durante suas investigações e constatações, a noção de sucesso tenha aparecido, ainda que em segundo plano, dado que, como pudemos averiguar, aquele que fala de fracasso fala também de seu oposto.

Nosso objetivo será buscar as evidências de sucesso nos processos inclusivos e, como veremos adiante, de que maneira as evidências de fracasso aparecem e se aparecem. Nesse caso, o sucesso da inclusão escolar vai depender do que exatamente? Das particularidades da criança em situação de inclusão? Do que o ambiente escolar oferece para o favorecimento desse processo? Ou da somatória destas e de outras variáveis? Tentaremos encontrar respostas para estas questões através da discussão dos dados colhidos nas entrevistas, como veremos no capítulo 8.

\subsection{Indicadores: o que são? Para que servem?}

A palavra indicador nos remete à ideia de algo que possa ser avaliado, mensurado, medido. Por sua definição, indicador é aquilo "que ou o que fornece indicações de pesos e medidas diversas (diz-se de um instrumento, dispositivo, etc); diz-se de ou organismo cuja presença (ou ausência) em determinada área serve como indicação da existência de certas condições ambientais." (Houaiss, 2007, p.1604). Portanto, indicador é algo que pode fornecer indicações diversas, de presença ou ausência de condições específicas, desde que determinadas previamente.

Entre os anos 2000 e 2008, um grupo de pesquisadores psicanalistas realizou uma pesquisa multicêntrica de indicadores de risco para o desenvolvimento infantil, a pesquisa IRDI. Projetada a partir de uma demanda do Ministério da saúde para a inclusão de indicadores psíquicos na ficha de acompanhamento do desenvolvimento $^{13}$, o grupo de pesquisadores desenvolveu, com base na teoria psicanalítica, o instrumento IRDI composto por 31 indicadores clínicos de risco para

\footnotetext{
${ }^{13}$ Instrumento integrante das Normas de Acompanhamento do Crescimento Infantil.
} 
o desenvolvimento infantil observados nos primeiros 18 meses de vida da criança. Dentre os diversos objetivos da pesquisa, o principal foi verificar o poder dos indicadores para a detecção precoce de problemas de desenvolvimento infantil. (Pesaro, 2011, p. 18).

Com uma amostra de 727 crianças de zero a dezoito meses, os exames foram divididos por faixa etária: de zero a quatro meses incompletos, de quatro a oito meses incompletos, de oito a doze meses incompletos e de doze a dezoito meses. Durante os exames, foram anotados os indicadores clínicos presentes, ausentes e não-verificados. Nesta pesquisa, a ausência dos indicadores sugere um risco para o desenvolvimento da criança. Ou seja, quando presentes, os IRDIs são indicadores de desenvolvimento, e quando ausentes, são indicadores de risco para o desenvolvimento. (Kupfer, et al., 2009).

Os indicadores da pesquisa IRDI, elaborados a partir de eixos teóricos extraídos da teoria psicanalítica, com base na noção psicanalítica de sujeito, entre eles: 1) suposicão do sujeito, 2) estabelecimento da demanda, 3) alternância entre ausência/presença e 4) instalação da função paterna que, segundo Kupfer et al. (2003), são expressões fenomênicas indicativas da instalação ou constituição da subjetividade. Segundo Pinto (2009), em linhas gerais, o primeiro eixo é a antecipação que a mãe ou o cuidador faz através da leitura de pequenos aspectos emitidos pelo bebê; o segundo é o jogo que possibilita uma espécie de intervalo entre a demanda e a satisfação que propiciará a simbolização no futuro; o terceiro é o reconhecimento pela mãe ou cuidador de reações involuntárias do bebê, como solicitações e pedidos dirigidos ao cuidador; o quarto e último é a entrada de um terceiro entre a criança e a mãe, que pode ser o pai, o interesse da mãe por algo além do bebê, uma atividade diferente da maternagem, que fundará para aquele ser uma primeira experiência de barramento. (Pinto, 2009, p. 24)

Faz-se importante notar que durante a estruturação da pesquisa não houve uma discussão sobre os fundamentos teóricos de cada indicador.

Nas palavras de Pesaro (2001):

Compreende-se que a constituicão psíquica é que vai marcar e sistematizar as funções orgânicas, anatômicas, musculares e neurofisiológicas do bebê ou da criança pequena a partir do laço que estabelece com o outro humano. Por isso, entra em jogo, na apreensão dos indicadores, o sistema de relação entre mãe e filho, o que nos leva a ter 
indicadores que dizem respeito ao bebê e outros que se relacionam à mãe ou ao cuidador, compondo, no conjunto, essa relação mãe-bebê (Pesaro, 2001, p. 25).

A construção dos indicadores, instrumento de leitura da constituição subjetiva, foi realizada por experts que, baseados na vasta experiência clínica e no saber acumulado pela Psicanálise, permitiu tal elaboração apoiada em noções e teorizações psicanalíticas. A composição dos quatro eixos na trama com o trabalho materno é o que permitirá a instalação de um sujeito psíquico. Contudo, a presença do sujeito psíquico só pode ser constatada através dos sinais que a criança produz. Os sinais são, portanto, os indicadores, que servem tanto para a referência de observação quanto para o conhecimento do curso da instalação de um sujeito bem como de seu desenvolvimento. "É preciso esclarecer que o que se expressa fenomenicamente não são evidentemente os eixos, e sim os seus indicadores" (Pinto, 2009, p. 24).

De maneira esclarecedora, Campana et al. (2012) fez questão de ressaltar que, por mais que seja relevante a existência de instrumentos capazes de detectar sinais de risco para o desenvolvimento e profissionais habilitados para utilizá-los, é importante levar em conta que nem todas as formas de expressão terão garantias de detecção dado que, por ser um protoloco, apresenta um escopo decorrente de seu recorte conceitual e limitações de aplicação. Desse modo, apontam para cinco princípios sobre o uso dos indicadores, dentre os quais destacamos:

3. O desenvolvimento é sempre um conjunto de especulações a partir das quais são lidas as transformacões observadas. Assim, o que se considera do desenvolvimento é sempre recorrtado pela abordagem de origem, que nunca recobre todas as possibilidades existentes.

4. A natureza da especulação é teórica e a observação é empírica. O que se observam são expressões possíveis, graças a certas contingências, de especulações oriundas do âmbito teórico. A isto chamamos indicador. (Campana et al., 2012, p. 3).

Tendo como objeto de pesquisa a inclusão escolar, pode-se levar em consideração que, do mesmo modo que os IRDIs, a natureza desta especulação é teórica e o que se busca observar, empiricamente, são as expressões possíveis decorrentes do campo teórico.

A partir deste instrumento, pensou-se em desenvolver um outro instrumento, análogo aos IRDIs, e que pudesse contribuir para o alcance do êxito na educação inclusiva, que chamaremos aqui por indicadores de sucesso da inclusão escolar. 


\subsection{Indicadores de sucesso na inclusão escolar}

Com base no instrumento IRDI, o presente trabalho iniciou uma pesquisa que buscou elaborar indicadores de sucesso para a inclusão escolar. Fazendo uma espécie de analogia à utilização do instrumento descrito, a intenção de verificar o sucesso baseia-se na ausência e na presença dos indicadores, sendo que a presença dos indicadores sugeriria o sucesso do processo inclusivo e a ausência indicaria o fracasso do processo inclusivo.

A elaboração de indicadores vem tentar objetivar aspectos que possam ser transmissíveis, saindo da exclusiva testemunha do observador ou pesquisador. Neste mesmo caminho, Freud, em Análise terminável e interminável (1937), tentou estabelecer um indicador para o final da análise.

Nas investigações a respeito das limitações e obstáculos que se interpõem no caminho de uma análise, Freud tentou estabelecer uma sinalização metodológica que indicasse o sucesso da análise e fixasse um limite para o tempo do processo analítico. A partir dos diversos obstáculos e processos defensivos, tornou-se possível avançar em suas investigações e afirmar que o que poderia indicar o sucesso do processo analítico seriam os desdobramentos sequenciais na fala do analisando, e não se ele apenas correspondia, negativa ou assertivamente, às interpretações do analista. Essa foi uma saída importante introduzida por Freud para que o analista não ficasse preso apenas como testemunha do analisando, podendo utilizar outras medidas possíveis que lhe servissem como referenciais para seu trabalho.

Atualmente, muito se fala em indicadores de qualidade de vida, indicadores de qualidade em educação e, como bem afirmam Kupfer e Voltolini (2005), "o uso de indicadores clínicos nas pesquisas da área da saúde já está consagrado (Kupfer \& Voltolini, 2005, p. 359)". Existem, atualmente, indicadores que surgem, em geral, para tentar complementar e preencher uma possível falta. Falta esta que não é da ordem do preenchimento. A busca pelos indicadores de sucesso para a inclusão não pretende corresponder a isso, na tentativa de preenchimento da falta. Longe de se tornar uma tábua de indicadores que sirvam à mestria - espécie de check-list -, os indicadores de sucesso da inclusão escolar têm como princípio observar e colher os elementos discursivos que apontem para o sucesso dos processos inclusivos 
fornecendo coerência e inteligibilidade aos fenômenos e questões com as quais os protagonistas da educação inclusiva se defrontam em seu cotidiano educacional. $\mathrm{Ou}$ seja, os indicadores visam contribuir para a reflexão e o encaminhamento da prática inclusiva que vem sendo realizada.

Apesar de encontrar-se no discurso do mestre ao buscar avaliar a inclusão escolar, não se pretende que os indicadores sejam seguidos e cumpridos. A intenção é a de que eles possam contribuir para cada um dos casos. Uma avaliação que parte do discurso do mestre, mas que oferece a possibilidade de não respondê-lo a partir do discurso do universitário, e sim, utilizá-lo como mais uma possibilidade de reflexão sobre cada caso em particular.

Contudo, vale acentuar que, como todo protocolo, os indicadores que buscaremos enunciar nesta pesquisa, se pautam principalmente pela "impossibilidade de estabelecer uma correlação absoluta entre uma especulação e uma expressão empírica da mesma sob a forma de algo observável.” (Campana et al., 2012, p. 3)”.

O que apresentamos aqui serve de base para a compreensão do que será introduzido mais adiante na discussão entre os dados obtidos e a teoria lacaniana dos quatros discursos, método utilizado para a análise dos discursos colhidos para a pesquisa e que instrumentaliza a discussão interdisciplinar. 


\section{A educação infantil diante da educação inclusiva}

Sabe-se que, atualmente, o ensino brasileiro é dividido em três níveis da educação básica: Educação Infantil, Ensino Fundamental, Ensino Médio, com diferentes graus em cada uma das divisões.

A educação infantil é considerada a primeira etapa da educação básica. Oferece atendimento para crianças de zero a cinco anos no qual se encontra, muitas vezes, a divisão do atendimento em creches para crianças de zero a três anos e nas chamadas pré-escolas para crianças de quatro a cinco anos. Os pais não são obrigados a matricular as crianças de zero a cinco anos, mas é dever do Estado garantir a possibilidade de que frequentem uma instituição educacional. Pela legislação brasileira, os municípios são os responsáveis pela oferta da educação infantil pública e gratuita.

O Ensino Fundamental, por sua vez, é classificado como o primeiro nível educacional, dado seu caráter obrigatório para crianças de seis a catorze anos. Isso significa que toda criança e adolescente entre seis e catorze anos devem estar na escola, sendo obrigação do Estado oferecer o ensino fundamental de forma gratuita e universal. A obrigatoriedade do Ensino Fundamental também implica reconhecê-lo como a formação mínima que deve ser garantida a todos os brasileiros, de qualquer idade. Em sua conclusão, o estudante deve dominar a leitura, a escrita e o cálculo. Outro objetivo desta etapa é desenvolver a capacidade de compreender o ambiente natural e social, o sistema político, a tecnologia, as artes e os valores básicos da sociedade e da família.

O Ensino Médio, também oferecido gratuitamente, deixa de ter o caráter obrigatório. Uma de suas funções é propiciar a formação ética, o desenvolvimento da autonomia intelectual e do pensamento crítico e a compreensão dos fundamentos científico-tecnológicos dos processos produtivos.

Conhecendo minimamente os níveis de ensino, pode-se presumir que existam características e diferenças marcantes entre etapas da educação. Enquanto a primeira tem o foco no lúdico, preconizando o "desenvolvimento integral da criança até seus anos de idade, em seus aspectos físico, psicológico, intelectual e social" (Lei de Diretrizes e Bases da Educação no 9394, de 1996, artigo 29º), ou seja, carateriza, portanto, que não apenas os aspectos diretamente ligados à aprendizagem devem estar 
envolvidos no processo de ensino, como todos os aspectos que formam um ser integral. Da segunda em diante, o foco encontra-se na capacidade do aluno em aprender. Há uma priorização da apreensão dos conteúdos sistematizados do ponto de vista curricular e acadêmico.

Essa divisão em etapas com focos tão diferentes nos leva a conceber que a proposta da inclusão em cada um dos níveis de ensino deve seguir os objetivos e os pressupostos de cada uma das etapas. Ou seja, a Educação Infantil, momento no qual o foco é o desenvolvimento global da criança, o lúdico em todas as suas instâncias é o caminho para o alcance dos objetivos previstos. Já no Ensino Fundamental, outras prioridades entram em cena, dentre elas as principais: o currículo acadêmico com a priorização da aprendizagem sistematizada e assim por diante. Mas o objetivo de introduzir aqui os níveis da educação brasileira não é o de dar ênfase nas diferenças, vantagens ou desvantagens que existem em cada uma destas etapas. E sim o de compreender a importância de se começar desde cedo o trabalho com a educação inclusiva.

A seguir, veremos a contextualização histórica da educação infantil no Brasil, seguida de sua importância para o desenvolvimento da criança bem como para a sua constituição psíquica.

\subsection{Um breve histórico da educação infantil no Brasil}

A educação institucionalizada para crianças de zero a seis anos não é uma novidade para a realidade brasileira, entretanto, apresenta um percurso ainda recente, que vem conquistando cada vez mais reconhecimento no cenário da educação.

$\mathrm{O}$ atendimento à criança de zero a seis anos, no Brasil traz na sua história marcas de um trabalho assistencial dirigido às crianças vindas de famílias pobres e trabalhadoras. Historicamente, o assistencialismo visava proporcionar à criança as condições que supunha the faltassem no lar. Segundo Nascimento (2008), as creches foram instituídas no Brasil na segunda metade do século 19, com o objetivo de acolher os filhos de trabalhadoras domésticas e operárias e acabaram sendo marcadas pela desvalorização devido a sua finalidade: alternativa ao abandono de crianças. Dessa maneira, as crianças frequentadoras das creches recebiam um tratamento precário, numa espécie de instituição provisória, sem caráter educacional.

Contudo, é somente com a introdução dos dispositivos apresentados na Constituição brasileira de 1988 e, mais recentemente, da Lei de Diretrizes e Bases da 
Educação nacional de 1996 (Lei 9.394/96), que introduziu a creche (crianças de zero a três anos) como primeira etapa da educação básica com a pré-escola (crianças de quatro a seis anos), que podemos encontrar outros significados para essa instituição, que deixou de ser vista como uma espécie de "'segundo lar' para tornar-se espaço de educação e cuidado para todas as crianças" (Ferrari \& Freller, 2008, p. 12). A finalidade da educação infantil é o desenvolvimento integral da criança, em seus aspectos físico, psicológico, intelectual e social, dividindo o atendimento em creche para crianças de zero a três anos e em pré-escola para crianças de quatro a seis anos. $\mathrm{O}$ reconhecimento da criança como um ser humano com direitos no presente, e não apenas no futuro, aponta para um novo paradigma na concepção de infância, com consequências sobre as práticas sociais e pedagógicas voltadas para as crianças pequenas. Com tais resoluções, o objetivo do trabalho passou a ser o de proporcionar o desenvolvimento integral da criança até os seis anos de idade.

A partir de então, cunhou-se a expressão Educação Infantil para designar todas as instituições de educação para crianças de zero a seis anos. Esse percurso aponta que a criança pequena passou a ter um espaço próprio e de relativa importância dentro da educação.

De acordo com o Plano Nacional de Educação (PNE):

Se a inteligência se forma a partir do nascimento e se há "janelas de oportunidade" na infância quando um determinado estímulo ou experiência exerce maior influência sobre a inteligência do que em qualquer outra época da vida, descuidar desse período significa desperdiçar um imenso potencial humano" (Brasil, 2001, p. 36).

Ainda segundo este documento (2001):

A educação infantil é a primeira etapa da Educação Básica. Ela estabelece as bases da personalidade humana, da inteligência, da vida emocional, da socialização. As primeiras experiências da vida são as que marcam mais profundamente a pessoa. (...) As ciências que se debruçaram sobre a criança nos últimos cinquenta anos, investigando como se processa o seu desenvolvimento, coincidem em afirmar a importância dos primeiros anos de vida para o desenvolvimento e aprendizagem posteriores. (...) A educação infantil inaugura a educação da pessoa. Essa educação se dá na família, na comunidade e nas instituições. As instituições de educação infantil vêm se tornando cada vez mais necessárias, como complementares à ação da família, o que já foi afirmado pelo mais importante documento internacional de educação deste século, a Declaração Mundial de Educação para Todos (Jomtien, Tailândia, 1990)." (Brasil, 2001, p. 40).

No entanto, essa situação modificou-se a partir da lei n. 11.274 de 6 de fevereiro de 2006, que alterou a redação dos artigos 29, 30, 32 e 87 da LDB de 1996, 
dispondo sobre a duração de nove anos para o Ensino Fundamental, com matrícula obrigatória a partir dos seis anos de idade a partir da qual estados e municípios tiveram até o ano de 2010 para instituir o novo modelo de ensino. Conforme o PNE, a determinação legal (Lei no 10.172/2001) de implantar progressivamente o Ensino Fundamental de nove anos, pela inclusão das crianças de seis anos de idade, teve duas intenções:

A primeira:

oferecer maiores oportunidades de aprendizagem no período da escolarização obrigatória e assegurar que, ingressando mais cedo no sistema de ensino, as crianças prossigam nos estudos, alcançando maior nível de escolaridade (Brasil, 2004, p. 13).

E a segunda:

a adoção de um ensino obrigatório de nove anos iniciando aos seis anos de idade pode contribuir para uma mudança na estrutura e na cultura escolar" (Brasil, 2004, p. $16)$.

Essas alterações na legislação ocorridas nos últimos anos promoveram novos direitos à criança, como o asseguramento da educação desde o nascimento. O Estatuto da Criança e do Adolescente - ECA (1990) enfatiza a condição da criança como cidadã que deve ser respeitada como um ser em desenvolvimento com necessidades e direitos específicos.

Contudo, tais mudanças no sistema de ensino brasileiro não invalidam a proposta de investigação dos processos inclusivos na educação infantil que passa, a partir do ano de 2010, a ocupar-se das crianças de zero a cinco anos.

A educação infantil abarca instituições de origens diversas: jardins da infância, creches, pré-escola etc. Cada qual com suas concepções de infância e educação que podem variar de instituições assistencialistas, às propostas construtivistas e suas derivações. Muitas delas tendo como base o Referencial Curricular Nacional - RCN, para a Educação Infantil que, segundo Souza (1998):

"foi concebido de maneira a servir como um guia de reflexão de cunho educacional sobre objetivos, conteúdos e orientações didáticas para os profissionais que atuam diretamente com crianças de zero a seis anos, respeitando seus estilos pedagógicos e a diversidade cultural brasileira" (Souza, 1998, p. 5).

O RCN propõe alguns eixos de trabalho orientados para a construção das diferentes linguagens pelas crianças e para as relações que estabelecem com os 
objetos de conhecimento: Movimento, Música, Artes Visuais, Linguagem Oral e Escrita, Natureza e Sociedade e Matemática.

Para além dos argumentos encontrados nos Referenciais Curriculares Nacionais, temos também outros fatores que partem do viés psicanalítico e contribuem para a valorização da educação infantil como um espaço rico e propício para pesquisas em Psicanálise e em Educação.

\subsection{Por que pesquisar inclusão na educação infantil?}

A escola de Educação Infantil desempenha a função de se dedicar à infância, de cuidar e educar, introduzindo as crianças na cultura do meio em que estão inseridas. Transmite valores, desenvolve competências variadas e procura auxiliar na formação de cidadãos conscientes e hábeis para realizarem escolhas, trilharem seus caminhos e se posicionarem no mundo.

Freud (1933) afirma que a educação produz na criança uma certa dose de desprazer, provocada pela renúncia às satisfações pulsionais imediatas, a fim de adaptar seu comportamento às normas civilizatórias. Portanto, educar é permitir o ingresso na cultura, situando a criança em relação à lei e aos códigos que organizam o social.

Educar é transmitir marcas simbólicas que possibilitam ao sujeito usufruir um lugar no campo da linguagem e a lançar-se nos caminhos do desejo, como nos declara Lajonquière (2001). O desenrolar desse processo, que pode ser denominado por filiação simbólica humanizante, "pressupõe na origem o investimento narcísico das crianças" (Lajonquière, 2001, p. 56). Esse ato através do qual o corpo do bebê recebe um banho de linguagem e as marcas do desejo do Outro primordial, pode ser entendido como o que possibilita a passagem da criança da posição de objeto para a de sujeito, marcando a sua entrada no campo do discurso.

Para Lacan (1962/1963), a organização subjetiva da criança não acontece de forma natural, é um processo de constituição. O ritmo do desenvolvimento é marcado pelo desejo do Outro, que inscreve o sujeito numa ordem filiatória. $\mathrm{O}$ bebê, ao nascer, encontra-se numa situação de extrema dependência. O Outro primordial — que assume a função materna — que virá alimentá-lo, higienizá-lo e conferir-lhe traços identificatórios, é o responsável pelas primeiras marcas fundantes de sua constituição. O bebê encontra-se numa posição de ser olhado, falado e tocado por esse Outro que, 
através desses cuidados, articula suas significações simbólicas às manifestações do bebê.

Flach e Sordi (2007) ressaltam a importância de diferenciar os cuidados prestados pelo Outro primordial e pelo Outro cuidador de uma instituição. O Outro primordial, como já apresentado, é aquele que vem inserir o bebê num laço filiatório e que está atravessado pela função materna. O Outro cuidador é aquele que insere a criança na cultura, no laço social e é atravessado pela função paterna, encarnada nas leis e regras sociais e ambos são fundamentais para a constituição psíquica da criança.

Portanto, para a Psicanálise a Educação é algo mais complexo do que o simples ato de ensinar e aprender (prática empregada pela pedagogia). Para a Psicanálise, a Educação está ligada ao processo de subjetivação, às funções materna e paterna que organizam o sujeito e o introduzem nos hábitos morais e civilizatórios. Cabe à família a implicação com as primeiras marcas simbólicas no bebê, inaugurando o espaço de subjetivação.

A escola de Educação Infantil pode ser entendida como um lugar de inscrição social que vai além do ato pedagógico. Ela está ligada à cultura e a inserção do sujeito na ordem da Lei. A escola oferece uma continuidade à educação iniciada na família, ao mesmo tempo em que supõe uma separação entre esses dois universos. Pode-se entendê-la como um espaço para além da família, que também pode se prestar à subjetivação, processo que também pode ocorrer na relação entre os educadores e as crianças.

A escolha desse lugar como foco desta pesquisa, que busca construir indicadores de sucesso na inclusão escolar, traz em si dois motivos principais: o primeiro diz respeito à importância fundamental da educação da criança pequena $\mathrm{e}$ sua implicação na formação de sua personalidade e de sua constituição psíquica, revelando-se um momento propício para a educação na diversidade. O segundo motivo, está ligado ao fato de eu me dedicar há doze anos ao trabalho na educação infantil e poder verificar, diariamente, a riqueza que esse campo pode proporcionar às crianças de zero a seis anos.

\subsection{Uma questão ética}

Antes de apresentar a definição do campo da pesquisa, é necessário fazer uma digressão a respeito da escolha das instituições e seus desdobramentos decorrentes. 
A escolha da primeira instituição pesquisada não foi uma tarefa simples. Isso porque, ao decidir realizar a pesquisa, tive que me deparar com a minha dupla relação: professora de apoio de inclusão da instituição pesquisada e pesquisadora pelo Instituto de Psicologia da Universidade de São Paulo. E ocupar essas duas funções, simultaneamente, não foi uma fácil empreitada, já que precisei manter alguma distância nos momentos certos, momentos dedicados à pesquisa, ao tomar a instituição como objeto da investigação. Esse movimento implicou em questões éticas que acredito serem fundamentais para o desenvolvimento desta dissertação.

Dentro da instituição, eu continuava a desempenhar a minha função como professora de apoio de inclusão,cargo a que fui incumbida de criar e desenvolver, em 2010. Coordenadora, com o objetivo de efetivar a socialização dos processos inclusivos em todas as suas instâncias: coordenação, equipe de professores, professores auxiliares, acompanhantes pedagógicos, além de promover o alinhamento do passado com o presente da prática através da documentação e da relação dos procedimentos com os conceitos. Ao mesmo tempo, precisei manter certa distância dos acontecimentos internos para realizar a tarefa de refletir sobre o trabalho desenvolvido pela escola,no qual me via totalmente envolvida.

Sabe-se que Freud era contra a idéia de um analista tratar de seus parentes "Com referência ao tratamento de seus parentes, tenho de confessar-me inteiramente perplexo" (Freud, 1912, p. 133). E essa posição não dizia respeito apenas à neutralidade absoluta do analista como também, à dificuldade de o paciente, diante de um parente, sentir-se confortável para lhe revelar "caixa preta" e falar tudo o que lhe "viesse à cabeça". A presença de um conhecido acabava por cercear o espaço para que as coisas pudessem circular livremente.

No entanto, conhecer a primeira instituição a fundo como eu tive a orportunidade de conhecer, devido aos doze anos de trabalho contínuo como professora, contribuiu para o mergulho nas imensas teias de significados que ali eram tecidos e enredavam as relações sociais ali estabelecidas. Entretanto, para conhecer a instituição através dos olhos de pesquisadora teria que me posicionar para olhá-la pelo avesso. Ao mencionar o olhar pelo avesso, autorizo-me a tomar emprestado a expressão empregada e desenvolvida por Lacan (1969/1970) em “O Seminário 17”, $O$ avesso da psicanálise, na qual a referência ao avesso seria o outro lado de um mesmo tecido. A junção das duas maneiras de olhar: o afetivo de funcionária há mais de uma 
década e o de pesquisadora crítica, contribuiu para atingir a diversa rede de significados para analisá-los de acordo com os objetivos propostos na pesquisa.

Contudo, existe uma séria discussão a respeito das possibilidades e pertinências de um pesquisador utilizar como campo de pesquisa a instituição na qual trabalha. Uma das particularidades desta discussão versa sobre a questão da ética, como se questiona Lerner (2008):

"(...) em que medida é ético que um profissional encarregado de algum tipo de atendimento use dessa condição para pesquisar algum aspecto ligado a ele?" (Lerner, 2008, p. 223).

Desse modo, afirma que uma das tarefas mais difíceis de tomar como objeto de pesquisa a instituição na qual se trabalha é adotar a necessária distância para realizar a análise das condições de constituição dos lugares em ação:

É necessário um afastamento para adotar um estranhamento forçado dessa realidade durante a fase de análises. (Lerner, 2008, p. 234).

Desenvolver uma pesquisa nessas condições implica, necessariamente, em desenvolver uma diferença de olhar, em assumir um distanciamento que possibilite o questionamento do campo que se constitui a fim de promover uma posição crítica em relação à instituição, sem se deixar englobar ou massificar, além de ter claro o objetivo que norteia o trabalho.

A escolha da segunda instituição não aconteceu por acaso. Ela foi escolhida justamente por apresentar um bom trabalho no que tange à educação inclusiva. Dado que a amostra da primeira instituição havia se esgotado, fez-se pertinente buscar uma nova amostra, pertencente a uma instituição distinta, que viesse complementar a amostragem por saturação (Fontanella et al., 2008), sobre a qual falaremos mais adiante.

Uma das diferenças que marcam as duas insituições, e que tomaremos aqui como fio condutor para a discussão da ética na presente pesquisa, encontra-se no fato de que na primeira instituição a pesquisadora pertencia ao quadro de funcionários, ao passo que na segunda, era uma pessoa de fora. Uma estrangeira. Mas, em ambas, era uma pesquisadora com objetivos definidos que seriam colhidos através da fala, dos discursos enunciados pelos sujeitos da pesquisa. 
Tomando como ponto central a análise de entrevistas e, por conseguinte, dos discursos, é preciso levar em conta que as particularidades do usufruto da língua revelam que o sujeito age sobre a sua falação: atribui nuances, significados e sentidos, ultrapassando o arbitrado. Neste sentido, há uma operação que se faz presente: que o dizer está para além do enunciado, está do lado do falante. A formulação lacaniana dos quatro discursos faz-de particularmente interessante para construir reflexões acerca desta questão, que se encontra implicada com o sujeito. Ao se referir sobre um sujeito que fala, há, sobretudo, que se considerar a quem se fala, quem fala e, sobretudo, de que lugar se fala. Algo se opera diferentemente dependendo destes contingentes, adquirindo um movimento especial entre o falante e seu interlocutor.

Dessa maneira, a presença da pesquisadora como entrevistadora em ambos locais de pesquisa produziu, inevitavelmente, efeitos na fala dos sujeitos entrevistados. Efeitos que não podem ser controlados, uma vez que dizem respeito somente ao sujeito que fala.

Todavia, é preciso considerar que na primeira instituição pesquisada, o fato de ser pesquisadora e também compartilhar o espaço profissional com as entrevistadas e sermos, portanto, colegas de trabalho, inevitavelmente produziu efeitos sobre as falas enunciadas nas entrevistas. Efeitos que, pela sutileza, não permitem uma mensuração. Desse modo, o que é possível extrair desta situação é que, na primeira instituição, os discursos possivelmente sofreram efeitos pelo fato de a pesquisadora ser conhecida e exercer um cargo hierárquico na instituição no que diz respeito ao tema da inclusão.

Entrementes, na segunda instituição, a pesquisadora era uma pessoa de fora da instituição, o que possivelmente não gerou efeitos decorrentes dos papéis hierárquicos. Mas não podemos deixar de levar em conta que, mesmo sendo de fora da instituição, alguns efeitos se produziram sobre os discursos das educadoras. Efeitos que veremos mais claramente na discussão dos dados

\subsection{Amostragem por saturação}

Como dito anteriormente, após o esgotamento da amostra na primeira instituição pesquisada, foi necessário ir em busca de novas amostras que pudessem encerrar a pesquisa através do método de saturação.

A amostragem por saturação é um instrumento conceitual constantemente empregado em relatórios e pesquisas de cunho qualitativo em diversas áreas no 
campo da saúde. Esse instrumento é utilizado para estabelecer ou fechar o tamanho final de uma amostra em estudo, encerrando a obtenção de novos elementos.

Segundo Fontanella et al. (2008):

O conceito encontra respaldo científico no pressuposto da constituição social do sujeito que, na Teoria das Representações Sociais, reflete-se no conceito de determinação social das representações individuais e, na Análise do Discurso, no conceito de determinação histórica e social das formações discursivas e da fala. (Fontanella et al., 2008, p. 24).

Tal ferramenta mostrou-se bastante útil para a presente pesquisa, contribuindo para a suspensão da inclusão de novos participantes, uma vez que os dados obtidos passaram a apresentar, segundo a nossa observação, uma certa repetição e redundância. Isso significa que informações fornecidas por novos participantes pouco acrescentariam ao material já coletado.

Segundo Fontanella et al. (2008), o fechamento da amostra resulta de uma análise por parte do pesquisador da valorização das diferenças ou do que se repete no conjunto. É possível considerar as diferenças como sendo aquilo que se percebe como individualizações da fala do entrevistado (nuances da linguagem associadas às vivências pessoais e aos contornos que o enunciado adquire), enquanto as semelhanças indicarão, predominantemente, o discurso do grupo ou da formação social a qual pertence o sujeito entrevistado. De acordo com os aspectos que a abordagem teórica desta pesquisa privilegia, optou-se por valorizar aquilo que se repete, evidenciando, dessa forma, o que optamos por chamar de indicadores de sucesso da inclusão escolar.

Fontanella et al. (2008) afirmam que, de acordo com os teóricos da Análise do Discurso:

(...) lê-se na fala de um indivíduo o discurso do grupo e o seu próprio discurso. Dizse "seu próprio discurso" não no sentido de ter sido construído fora de um contexto histórico e interacional (...), mas no sentido da forma original pela qual esse discurso mais amplo foi assimilado e organizado pelo indivíduo. (Fontanella, 2008, p. 23)

Isso significa que aquilo que o indivíduo entrevistado diz, a maneira como diz e o conteúdo dito, está relacionado às suas particularidades, o que pode ser identificado com as diferenças. Entretanto, o contexto no qual se encontra tal 
indivíduo é limitado pelo tempo, pelo espaço social a que pertence, o que o leva a ser identificado como pertencente a um certo grupo.

Ainda de acordo com autores acima citados, apesar de ser um procedimento aparentemente simples e de fácil acesso, ele corre o risco de ser aplicado de forma acrítica ou extremamente subjetivista, pois trata-se de uma confiança empírica de que a amostra está saturada.

No caso do presente trabalho, todas as educadoras da primeira instituição pesquisada - que se encontravam dentro da delimitação do campo estabelecido participaram da pesquisa, fato que configuraria uma amostra fechada por exaustão (e não por saturação) suficiente para saturar algumas ou todas as categorias formuladas pela pesquisadora. Seria, contudo, uma constatação de saturação não decorrente do próprio processo de pesquisa.

Entretanto, por ser considerado um emprego controverso do conceito de saturação, optou-se por continuar a pesquisa em uma instituição distinta (que apresentasse características semelhantes à primeira, como por exemplo: o trabalho com a Educação Infantil) até que a saturação se desse por excelência. A avaliação da saturação teórica a partir de uma amostra é realizada através de um processo contínuo de análise dos dados, começado já no início do processo de coleta. Tendo em vista as questões colocadas aos entrevistados, que devem refletir os objetivos da pesquisa, a análise preliminar busca o momento no qual poucos conteúdos novos aparecem.

Ao longo da análise da entrevistas, como veremos no capítulo 7, notaremos que nenhum dos discursos analisados é igual ao outro, mas todos apresentam elementos comuns entre si. 


\section{6}

\section{A teoria dos quatro discursos e a educação inclusiva}

\section{A teoria lacaniana dos quatro discursos ${ }^{14}$}

No Seminário 17, O avesso da psicanálise, Lacan (1969/1970) mostrou-se bastante investido sobre a discussão a respeito da cultura e da cena social abarcando grandes questões da contemporaneidade. O momento deste seminário encontra-se intensamente marcado pelo clima polêmico presente no contexto universitário da sociedade francesa, desencadeado pelo movimento ocorrido no ano de 1968. Desse modo, a formulação lacaniana da teoria dos quarto discursos, desenvolvida nesse seminário, buscou explicitar lugares sociais. Pereira (2005) já nos apontou o motivo de essa teoria ser tão utilizada como instrumento de análise uma vez que se interessa pelo que o sujeito produz em seu enlaçamento com a ordem social. Portanto, nossa hipótese de utilizar tal teoria como método de análise para esta pesquisa é a de que os atos docentes promovidos em conjunto com as circunstâncias institucionais em relação às crianças em situação de inclusão, podem se valer do entendimento dos quatro discursos, para identificar indícios de sucesso e fracasso nos processos inclusivos.

Em Prefácio ao livro Juventude desorientada, de Aichhorn, Freud (1925) se refere a essas três profissões impossíveis, mas no lugar de analisar, ele utilizou, à princípio, o termo curar:

Em um primeiro estádio, aceitei o bon mot que estabelece existirem três profissões impossíveis - educar, curar e governar - , e eu já estava inteiramente ocupado com a segunda delas (Freud, 1925, p. 307; grifos do autor).

E mais tarde, em Análise terminável e interminável (1937), substituiu curar por analisar:

Quase parece como que se a análise fosse a terceira daquelas profissões 'impossíveis' quanto às quais de antemão se pode estar seguro de chegar a resultados

\footnotetext{
14 No ano de 1972, Lacan cita rapidamente um quinto discurso: o discurso do capitalista. Nesse, contrariamente aos outros, os termos não são isolados, cada um alimenta no outro uma reação em cadeia. No presente momento da dissertação, ele não será considerado uma vez que não aparece no desenvolvimento apresentado no Seminário 17 (1969/1970).
} 
insatisfatórios. As outras duas, conhecidas há muito mais tempo, são a educação e o governo (Freud, 1937, p. 265).

Essas profissões declaradas como impossíveis representam na teoria freudiana, diferentes maneiras de se estabelecer laço social. Diferentes maneiras de tentar contornar o impossível. Em seu texto, O mal-estar na civilização (1930), Freud destaca que a fonte de sofrimento mais penosa para o ser humano é resultante das relações mútuas com outros seres humanos na família e na sociedade, relações decorrentes do pertencimento à civilização. Contudo, a própria civilização impõe sacrifícios enormes ao ser humano, não apenas em relação à sexualidade como também à sua agressividade,

O homem civilizado trocou uma parcela de suas possibilidades de felicidade por uma parcela de segurança. (Freud, 1930, p. 119).

Portanto, ao escolher a segurança optou por ingressar no universo simbólico da linguagem. Ao decidir-se pela linguagem, renunciou à possibilidade de acesso ao real, que se tornou para todo ser humano impossível de ser totalmente acessado. Dessa maneira, o mal-estar que ronda toda a forma de laço é o preço que pagamos pela perda do paraíso da eterna felicidade.

Entretanto, não podemos deixar de enfatizar o que Petri (2003) muito bem nos lembrou a respeito da natureza do laço social, exaustivamente trabalhada pela Psicanálise desde o texto Totem e tabu (1913), no qual Freud descreve o mito fundador do humano:

Laço, no seu entendimento literal, é um nó que desata sem esforço, uma armadilha de caça, uma aliança, um vínculo. Social seria relativo à sociedade, à cultura. Ou seja, laço social seria o que permite ao sujeito fazer um vínculo com a cultura, ainda que seja através de um nó frágil, uma aliança com o universo simbólico que rege as relações humanas (Freud, 1913, citado por Petri, 2003, p. 71).

Retomando tais considerações, Lacan (1969/1970) elabora a sua teoria dos quatro discursos, quatro maneiras de se estabelecer laço social que vão sobrepor-se às três profissões citadas por Freud (1925/1937). A elas Lacan acrescentou uma outra modalidade de laço: o fazer desejar, completando, por fim, as quatro maneiras de nos relacionarmos com o outro, inaugurando quatro modalidades de discurso. 
As três profissões — se é que se trata de profissões - são então (...), governar, educar e analisar. Não se pode deixar de ver o recobrimento entre estes três termos e aquilo que distingo este ano como o que constitui o radical dos quatro discursos (Lacan, 1969/1970, p. 177).

Dessa forma, é possível pensar que os laços sociais que os discursos tentam articular são momentâneos, instáveis e incapazes de amarrar todo o Real ${ }^{15}$ presente. As modalidades de discurso e, portanto, de estabelecer laço trazem consigo algo do Real. No entanto, ao escolher o universo simbólico, o homem renuncia à possibilidade de acesso ao Real, o que implica em uma inevitável perda, algo impossível de ser totalmente representado. Havendo uma perda, haverá sempre um mal-estar.

O conceito de discurso aparece em vários momentos no ensino de Lacan, inicialmente como equivalente à fala, ao dito. Contudo, é no seminário 17, O avesso da psicanálise (1969/1970) que vai conceber o discurso para além da fala, que prescinde da palavra e ultrapassa sua função de mediadora na relação com o outro. Um discurso sem palavras fundador de todo laço social:

É que sem palavras, na verdade, ele (o discurso) pode muito bem subsistir. Subsiste em certas relações fundamentais. Estas, literalmente, não poderiam se manter sem a linguagem. Mediante o instrumento da linguagem, instaura-se um certo número de relações estáveis, no interior das quais certamente pode inscrever-se algo bem mais amplo, que vai bem mais longe do que as enunciações efetivas (Lacan, 1969/1970, p.11).

Nesse sentido, os discursos nos apresentam formas peculiares de endereçamento ao outro e ao objeto causa do desejo, criando modos de posicionamento e de enlaçamento estáveis, assim como a manifestação do gozo através de suas particulares maneiras. Para entender as posições dispostas, Lacan propôs quatro modalidades discursivas às quais denominou: o discurso do mestre, o da histérica, o do universitário e o do analista.

Em cada uma dessas modalidades discursivas existem quatro lugares que, embora fixos, são diferentes: o lugar de agente, o lugar do outro, o lugar da produção e o lugar da verdade, distribuídos da seguinte forma em seu algoritmo:

\footnotetext{
${ }^{15}$ Real, Simbólico e Imaginário são expressões propostas por Lacan. Tomemos o Real como aquilo que diz do campo do inominável, expulso da realidade pela intervenção do Simbólico - campo dos significantes, ou da palavra - e por fim, o Imaginário, como o campo da relação dual, da imagem especular e ideal. São esses três campos os responsáveis pela constituição do sujeito do inconsciente.
} 


$\frac{\text { Agente }}{\text { Verdade }} \rightarrow \frac{\text { Outro }}{\text { Produção }}$

$\mathrm{O}$ agente denominado por Lacan como dominante dirige-se ao outro por meio de uma flecha, e esse outro pode ser entendido como aquele que trabalha, produzindo algo para que a verdade surja. A verdade indica o que mobiliza a ação do discurso enquanto a produção indica o resultado do trabalho. Ainda nesse seminário veremos que a flecha na parte superior do algoritmo significa a impossibilidade e a sua ausência na parte inferior significa a não relação entre a produção e a verdade.

Para cada um dos lugares existe um enredamento constituído pela lógica do significante proposta por Lacan (na qual eles se articulam entre si como significantes), que é representada pelos elementos discursivos: S1 (o significante mestre), S2 (a bateria dos significantes, o saber), \$ (o sujeito) e $a$ (objeto perdido). É da relação fundamental S1-S2 que emerge o sujeito. Ou seja, o sujeito é o que um significante representa para outro significante. Quando S1 intervém no campo dos outros significantes surge \$, o que Lacan chamou de sujeito dividido. Embora o sujeito seja um efeito do significante, ele não pode ser integralmente representado por ele e, por esse motivo, surge dividido, barrado. De todo esse trajeto surge algo definido como objeto perdido, o objeto $a$, o resto que promove o giro dos discursos, justamente por representar a perda necessária para o estabelecimento dos laços sociais.

Lacan extrai a função de objeto perdido do discurso freudiano sobre o sentido da repetição no ser falante. Mas, ressalta que não se trata da repetição de qualquer efeito de memória no sentido biológico, e sim da repetição que tem certa relação com o limite, que nessa situação, pode ser chamado de gozo.

Nas palavras de Boudard (2000), que muito bem descreve a cadeia significante dos discursos:

A teoria lacaniana dos quarto discursos nos diz que quando tomamos a palavra, ocupamos, antes de qualquer coisa, um lugar. Mas qual? Pois existem diferentes lugares de onde podemos falar, interpelar o outro, e o efeito do que se dirá aí será diferente em cada um desses lugares. Assim, coloca-se em primeiro plano o lugar a partir do qual se toma a palavra: o lugar do agente. Em seguida, trata-se de saber a quem se fala, a que outro se dirige essa palavra. (...) Essa palavra endereçada ao outro tem um efeito (além do efeito sujeito): é o produto do discurso. Essa produção tem uma outra causa, mais verdadeira que o agente do discurso, a qual ele é apenas o semblante. Essa causa, motor do discurso, é a verdade, em nome da qual se fala o agente. (Boudard, 2000, p. 64) 
Podemos entender que toda essa classificação é realizada a partir do agente do discurso que mobiliza e ordena toda a cadeia discursiva. Sempre que o outro é interpelado pelo agente, fica colocado numa determinada posição. No entanto, a palavra endereçada ao outro produz um efeito nomeado como produção, que por fim, tem uma outra causa, a verdade, sendo essa o motor do discurso. E é dessa forma que os laços sociais, relações ou vínculos, são estabelecidos.

$\mathrm{Na}$ formulação lacaniana dos quatro discursos teremos sempre uma estrutura com lugares fixos: o agente, o outro, a produção e a verdade e quatro termos móveis: $\mathrm{S} 1, \mathrm{~S} 2, \$$ e $a$, que se rodiziam em suas posições de acordo com o discurso posto em ação.

É importante ressaltar que os discursos não são como adereços que podem ser colocados, usados e retirados à vontade. Segundo Fink (1998), a mudança de discursos requer que determinadas condições sejam atendidas.

$\mathrm{O}$ analista nem sempre funciona no discurso analítico; por exemplo, na medida em que ensina o analista pode muito bem adotar o discurso da universidade ou o discurso do mestre ou até mesmo o discurso da histérica (Fink, 1998, p. 160).

O ensino de Lacan é pontuado pela criação de uma escrita formal de letras conhecida como a álgebra lacaniana. A associação combinatória dessas letras foi denominada por matemas. Segundo Lacan (1972/1973), o matema está relacionado com a fundamental questão da transmissão da Psicanálise, pois é só através dele que a Psicanálise é capaz de ser transmitida integralmente. O matema, representante das cadeias discursivas é a maneira possível de dar conta do impossível que é o Real. Boudard (2000) afirma que "esses quatro discursos são quatro modos da relação impossível com o gozo (Boudard, 2000, p. 66)". Os quatro discursos podem ser considerados quatro não-relações de $\$$, o sujeito barrado, $\operatorname{com} a$, o objeto perdido mas que, paradoxalmente, permitem uma relação. Cada um deles, de certa maneira, evidencia o gozo impossível, ou seja, apontam para a impossibilidade de o sujeito alcançar o seu objeto perdido. 
Essa sofisticada construção lacaniana de influência estruturalista ${ }^{16}$ articula as dimensões de discurso e sujeito, entendendo o sujeito como efeito das relações discursivas.

Geralmente considera-se o discurso do mestre como sendo o discurso matriz dos outros discursos, uma vez que foi o primeiro a ser apresentado por Lacan no Seminário 17, já que ele se enuncia a partir da relação fundamental S1-S2. Portanto, é possível afirmar que a partir de um discurso matriz, derivam-se os outros por um quarto de giro dos elementos que os compõem. Cada um quarto de torção, revela os lugares fixos do agente, do outro, da produção e da verdade (mola propulsora do discurso), representados pelos termos móveis $\mathrm{S} 1, \mathrm{~S} 2, \$$ e $a$, estruturando dessa forma, os quatro diferentes discursos:

Discurso do mestre

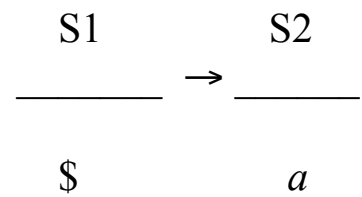

Discurso do analista

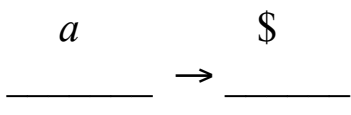

S2

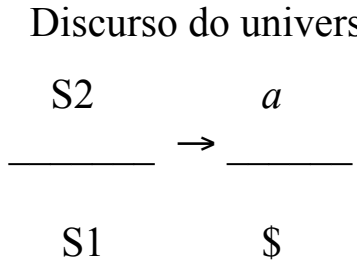

Discurso da histérica

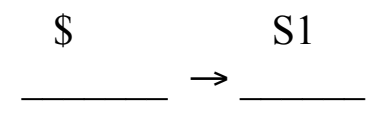

a
S2

Segundo Rahme (2010), nos quatro discursos o significante-mestre, S1, é o elemento que produz uma espécie de ordenação nas ideias que se constróem ao longo de um escrito ou de uma conversa, e possibilitam a leitura de um texto ou a atribuição de um determinado tom a uma discussão.

Portanto, nessa teoria lacaniana a posição dos elementos discursivos no lugar de agente determina o seu valor. Desse modo, S1 indica o discurso do mestre; S2

\footnotetext{
${ }^{16}$ Classificação que Lacan aceita, uma vez que ele identifica o estruturalismo com a seriedade (1968/1969). Essa classificação apenas veio contribuir para a comprovação da seriedade de sua teoria dos discursos.
} 
indica o discurso do universitário; $\$$ o da histérica; e $a$ (também conhecido por pequeno a) corresponde ao discurso do analista.

De certa forma é possível afirmar que os discursos de Lacan iniciam-se com o discurso do mestre, seja por razões históricas que Lacan foi buscar na dialética hegeliana, seja pelo fato de que esse discurso incorpora a função alienadora do significante ao qual estamos todos assujeitados: é a matriz fundamental do vir a ser do sujeito através da alienação ${ }^{17}$.

O lugar do agente é ocupado por S1, o significante-mestre que nos diz que deve ser obedecido. Não há razão para que ele tenha poder, ele simplesmente tem (Fink, 1998). O discurso do mestre é aquele que evidencia o funcionamento da sugestão e neste sentido, é o avesso do discurso da psicanálise.

Teoricamente, no discurso do mestre, o senhor ou governante autoriza-se com base na sua subjetividade, esperando obter do escravo ou governado a produção de objetos para usufruir. Objetos que podem ser chamados de objetos de gozo.

No discurso do mestre (...) não há relação entre o que vai mais ou menos se tornar causa do desejo de um cara como o mestre - que, como de costume, não compreende nada disso - e o que constitui sua verdade. (...) Em seu ponto de partida fundamental, o discurso do mestre exclui a fantasia. E é isso exatamente o que faz dele, em seu fundamento, totalmente cego. (Lacan, 1969/1970, p. 114)

Esse é o discurso por excelência, já que sua tese é a de que tudo deve submeter-se à lei. O mestre não se preocupa com o saber, desde que tudo funcione, desde que seu poder seja mantido ou aumente, tudo está bem. Segundo Lacan $(1969 / 1970)$

um verdadeiro senhor não deseja saber absolutamente nada - ele deseja que as coisas andem. (Lacan, 1969/1970, p. 23)

O discurso da histérica se dá a partir de um quarto de rotação a partir do discurso do mestre, que não diz respeito à neurose histérica anteriormente indicada por Freud, e sim ao fazer desejar, ao colocar-se como objeto de desejo. Nesse discurso, o sujeito barrado (\$) ocupa a posição de agente como dominante e se dirige a S1 colocando-o em questão, produzindo nesse outro um desejo de saber, S2. O

\footnotetext{
${ }^{17}$ Conceito desenvolvido por Lacan no artigo "O estádio do espelho como formador da função do eu", do ano de 1949.
} 
discurso da histérica parte de uma insatisfação relativa a condição de sujeito barrado (faltante) que, ao endereçar-se ao outro em busca de uma resposta, provoca a emergência do desejo de saber, promovendo no lugar da produção S2, o saber. Ao dirigir-se ao mestre, a histérica demanda que ele produza um saber e depois tenta invalidar suas teorias. Lacan indaga-se sobre o que quer a histérica e afirma que

"Ela quer um mestre (...) que saiba muitas coisas, mas, mesmo assim, que não saiba demais (...) quer um mestre sobre o qual ela reine. Ela reina, ele não governa" (Lacan, 1969/1970, p. 136).

No terceiro giro de um quarto de volta, chegamos ao discurso do analista, no qual o objeto $a$, como causa de desejo, é o agente que ocupa a posição predominante. Nesse discurso, o analista interroga o sujeito na sua divisão (\$) no lugar do outro, que produz um significante-mestre (S1) que se encontra sob a barra e ocupando o lugar da verdade, encontra-se o saber (S2). O S2 aqui representado no lugar da verdade é diferente daquele dominante do discurso da universidade, como veremos logo a seguir. O saber aqui em questão é o saber inconsciente, que se encontra sobreposto na cadeia significante e que precisa ser subjetivado por ainda estar escondido.

Lacan considera o discurso do analista como o oposto do discurso de mestre, ou seja, o seu avesso. É um discurso que se encontra no lado oposto ao desejo de dominar.

O discurso do universitário surge como o quarto de volta a partir do discurso do analista, quando o saber (S2) ocupa a posição de agente, o objeto $a$ situa-se no lugar do outro que produz um sujeito barrado (\$) e no lugar da verdade, encontra-se (S1), o significante-mestre. No discurso do universitário o saber ocupa o lugar dominante que é acionado sobre o outro tomado como objeto. Lacan (1969/1970) afirma que:

O S2 tem aí o lugar dominante na medida em que foi no lugar da ordem, do mandamento, no lugar primeiramente ocupado pelo mestre, que surgiu o saber (Lacan, 1969/1970, p. 109).

O saber sistemático é a autoridade máxima onde tudo possui uma razão possível. Com S2 no lugar dominante do discurso, sustenta-se uma verdade de que é preciso sempre saber mais, ao mesmo tempo em que provoco no outro o sentimento 
de nada saber, reduzindo-o a mero objeto, produzindo um sujeito barrado (\$) que não tem acesso à verdade ocupada pelo significante-mestre (S1).

No discurso do universitário, o outro, estudante, ocupa a posição daquele que apresenta uma condição de saber eternamente insuficiente, fadado a sempre ter que saber mais e mais.

A elaboração de Lacan sobre os discursos como maneiras específicas de um sujeito ligar-se ao outro considerando o discurso como forma de laço social, ocupa um lugar primordial em seu ensino, do qual decorre o aforismo de que o inconsciente é estruturado como linguagem, submetido, portanto, à lógica significante. Desse modo, só é possível abordarmos o sujeito, dentro do laço social, uma vez que ele é efeito de produção discursiva, o que um significante representa para outro significante.

Contudo, não podemos deixar de enfatizar que, ao contrário do que parece, a rede dos discursos não é seqüencial, portanto, as estruturas discursivas não seguem uma linha hierárquica. A posição mantida por Lacan era a de que os discursos são efêmeros. Como já afirmado anteriormente, o analista (e não apenas ele) pode agenciar ora no discurso do mestre, ora no discurso do universitário, bem como no discurso da histérica. O que ocorre é que na dinâmica do deslizamento discursivo, há a passagem de um discurso ao outro. Nesse sentido, por mais que se agencie através do discurso do mestre, por exemplo, no momento da passagem deste a um outro discurso (na mudança do lugar de agente do discurso) não podemos deixar de levar em conta o manejo do discurso do analista.

Silveira (2011) deixa claro que Lacan em seu seminário 20, Mais ainda (1972/1973), afirmou que sempre que há mudança de discurso, há uma passagem pelo discurso do analista. O discurso do analista nada mais é do que um discurso de passagem para os outros discursos.

Entretanto, no deslizamento de um discurso ao outro ocorre um movimento que sempre se retorna, por tendência ocasionada pelo efeito da entropia do discurso, ao lugar do mestre. Nesse efeito de entropia, nesse desperdício, algo se faz necessário para compensar essa perda, o que leva à busca de um gozo a se repetir. É dessa forma que Lacan (1969/1970) vai introduzir a noção de um "mais-de-gozar" a recuperar. Na tendência a ir em busca do mais de gozar, retorna-se sempre ao discurso do mestre, fórmula que situa o momento inaugural em que S1, o traço unário, ao incidir sobre S2, o saber já constituído, fazendo-o trabalhar, faz surgir \$ e também uma perda, o 
objeto $a$.

Dessa conceituação é possível entender que sujeito e discurso são dimensões indissociáveis, fato que Freud (1921) afirmou ao abordar a relação entre a convivência em grupo e o indivíduo, na qual ocorre uma rara proeminência de interesses pessoais. Portanto, é possível admitir que um indivíduo tenha seus padrões morais elevados na vida em grupo o que nos leva a reconhecer a indissociabilidade entre o coletivo e o singular.

\subsection{Inclusão escolar e os quatro discursos}

$\mathrm{Na}$ introdução deste trabalho, pudemos apresentar algumas pesquisas nos campos da Psicanálise e da Educação que se propuseram investigar, mais precisamente, os processos de inclusão escolar e se utilizaram da teoria lacaniana dos quatro discursos como método de análise das posições discursivas dos protagonistas envolvidos nessa temática, sejam eles as crianças, os educadores ou até mesmo os profissionais que se ocupam dos tratamentos para além da escola.

Alem dos trabalhos de Rahme (2010), Ormelezzi (2006), Bastos (2003), encontramos outros trabalhos (dos quais escolhemos citar apenas os mais significativos dada a relevância para esta pesquisa), que também puderam utilizar desta teoria como método de análise sobre as diferentes posições discursivas no campo da educação inclusiva e os efeitos gerados nos processos inclusivos propriamente ditos. Faremos um recorrido sobre esse material afim de demonstrar como essa teoria vem sendo utilizada na compreensão e na investigação nos campos da Psicanálise e da Educação, mais especificamente na educação inclusiva.

Em sua pesquisa, Lerner (2010) buscou desvelar posições discursivas (que partiam de lugares diferentes e de relações diversas com a questão da deficiência) existentes no Fórum Permanente de Educação Inclusiva de discussão sobre a inclusão, tomando em análise o discurso veiculado pelo fórum. A autora se deparou com diversos temas que foram insistentemente debatidos, dentre os quais podemos condensar na empreitada pela busca pelo ideal, movimento no qual ocorre, com freqüência, a substituição de um ideal por outro. Ou seja, no qual há o deslizamento de um discurso (histérico) a outro, o do mestre, aquele que vem definir um rumo a ser seguido. E conclui que a presença da Psicanálise neste campo pode servir como um discurso que 
faça face à perspectiva totalitarista do discurso do mestre, para que a inclusão não se reduza a uma religião (Lerner, 2010, p. 8).

Braga (2006) buscou investigar, a partir do processo de inclusão de uma criança com "transtornos invasivos do desenvolvimento", a maneira pela qual a posição discursiva do professor pôde afetar o seu processo inclusivo. Após a análise, ela identifica que a posição discursiva do educador tem efeitos sobre o processo inclusivo, mas que nem sempre alcançam os efeitos necessários para que a relação professor-aluno propicie a inclusão.

Ribeiro e Bastos (2007) procuraram investigar o lugar do analista na extensão da Psicanálise à inclusão escolar. A pesquisa teve como objetivo acompanhar a inclusão de crianças autistas e psicóticas na rede regular de ensino do Rio de Janeiro. A psicanalista esteve presente nas reuniões com os profissionais do serviço clínico de atendimento dessas crianças e com a equipe pedagógica das escolas. Nas reuniões, pôde discutir os efeitos da segregação e dos laços sociais e analisar os discursos correntes sobre a criança, abrindo o espaço para que o impossível de educar em cada caso não ficasse preso à impotência dos educadores.

Apesar de existirem outros trabalhos que contribuiriam para a demonstração da utilização e validade da teoria lacaniana como método de pesquisa, vamos nos deter neste ponto, pois nosso objetivo em citar os trabalhos acima era o de apenas revelar como essa teoria tem se apresentado e vem sendo utilizada no campo da educação inclusiva.

Portanto, dada a finalidade desse trabalho, abordaremos os quatro discursos propostos por Lacan tendo como perspectiva sua retomada nos capítulos seguintes, seja na discussão sobre o lugar que as crianças em situação de inclusão ocupam e/ou passam a ocupar na rede discursiva educacional, seja no que se refere especificamente à análise e discussão dos dados provenientes da pesquisa de campo. 


\section{7}

\section{As entrevistas}

A modalidade de entrevista escolhida foi a semi-estruturada, com proposituras abertas no início, pois permite que o entrevistado discorra livremente sobre o assunto e possibilita que conteúdos latentes possam vir à tona na reconstrução dos sentidos para as experiências relatadas.

Foi proposto ao entrevistado - "Gostaria que você me dissesse sobre a sua experiência como professor de uma criança em situação de inclusão, sobre quem é essa criança, como o trabalho é desenvolvido e se a escola oferece algum tipo de suporte para viabilizar esse trabalho" - essa primeira proposição permite que a partir dela, outras possam ser feitas, de acordo com as informações que são, ou não, fornecidas pelo entrevistado.

As entrevistas foram gravadas num dispositivo de áudio e foi o método que se mostrou mais adequado para captar todas as informações necessárias do modo exato como foram expressas. Após cada entrevista, foi realizada a transcrição para o registro escrito, um processo cauteloso que cuidou para que a riqueza do conteúdo não ficasse comprometida.

A interpretação dos dados das entrevistas foi feita com base no referencial psicanalítico, o qual além de fornecer instrumentos para a análise dos discursos envolvidos na pesquisa, serviu de base para a compreensão das reflexões teóricas.

Das entrevistas, pretende-se assinalar os elementos significativos obtidos, que indiquem possíveis aspectos de sucesso na inclusão destas crianças, provenientes da atuação dos professores com seus respectivos alunos.

As análises das entrevistas estão agrupadas por criança. Foram assinalados os elementos significativos construídos nos discursos dos educadores como indicativos da posição subjetiva das crianças, orientando-se pelas seguintes questões:

1) $\mathrm{O}$ que emergiu dos discursos dos educadores que enuncia como essas crianças se manifestam no espaço escolar?

2) O que se mostrou significativo em termos de sucesso no processo inclusivo no discurso dos educadores?

3) Quais são os efeitos sofridos pelas crianças que podemos constatar como possíveis indicadores de sucesso em seus processos inclusivos? 
Nos recortes das entrevistas existem algumas palavras ou frases que aparecem destacadas em negrito. Estes grifos são partes dos discursos que consideramos elementos significativos para entender os movimentos subjetivos de cada relato, que forneceram aspectos importantes para a elaboração dos indicadores de sucesso da inclusão escolar.

\subsection{A primeira instituição pesquisada ${ }^{18}$}

A presente pesquisa ocorre, primeiramente, em uma escola de educação infantil da rede particular de ensino da cidade de São Paulo. Fundada no ano de 1976, inicialmente como um ateliê de artes, expandiu-se quatro anos mais tarde para Educação Infantil, atendendo ao projeto fundador e à demanda das famílias. Preocupada em aproximar reflexões teóricas à prática cotidiana, a escola criou métodos, formas de organização e conhecimento sempre fundamentados na experiência e na sensibilidade.

No ano 2000, com o intuito de oferecer continuidade ao trabalho desenvolvido na Educação Infantil, inaugurou-se o Ensino Fundamental 1 e, mais tarde, também o Fundamental 2. Atualmente a escola desenvolve o trabalho até o Ensino médio.

A escola pesquisada, sendo uma escola de educação regular, tem como missão oferecer à sociedade uma prática e uma reflexão educativas em permanente evolução, pautadas na concepção da formação integral de um indivíduo autônomo, atuante e crítico, socialmente responsável e comprometido com a valorização dos conhecimentos científicos, artísticos e culturais; assim como atento à diversidade $\mathrm{e}$ às questões socioambientais; e capaz de compreender a si e ao mundo através das múltiplas linguagens e representações.

Todo projeto pedagógico tem como base as concepções de sujeito e de educação e desenvolvimento. Essas concepções constituem a base para o seu pensar e, consequentemente, para o seu fazer educativo.

Ao apontar o sujeito, a escola refere-se não apenas ao aluno, mas também ao educador e a todos os membros que compõem a sua comunidade (os professores, os coordenadores, os funcionários administrativos e as famílias). Acredita que todo o

\footnotetext{
${ }^{18}$ Todas as informações que descrevem a instituição pesquisada, bem como seus espaços de formação foram gentilmente cedidas pela instituição e algumas das informações encontram-se no site da escola. Se por ventura as informações entre as duas instituições pesquisadas forem discrepantes, isso se deve ao fato de que os materiais fornecidos por ambas apresentavam diferentes graus de informações.
} 
processo educativo é baseado numa ação ativa de duas vias: educadores e alunos juntos, pesquisando e realizando descobertas, e frisa que o educador pode ser o professor, assim como o ambiente físico, o grupo e todos que fazem parte dessa comunidade.

Para esta escola o conhecimento não é adquirido e, sim, construído. Portanto, é não linear, podendo ter idas e vindas, partindo de diferentes canais de compreensão e entendimento. Essa construção também é valorizada entre os iguais, entre os próprios alunos. É uma troca de outra natureza, diferente da que se dá com o adulto educador. São sujeitos em posições semelhantes, contudo, com estratégias diferentes para chegar às descobertas. Este exercício não apenas traz o valor de solidariedade e de tolerância - na medida em que faz os sujeitos lidarem com as diferenças - , como também oferece possibilidades de trabalho em conjunto.

Ainda na relação do sujeito com o mundo, a escola pesquisada considera possível identificar diferentes linguagens que o auxiliam a compreender os significados da cultura. É também por meio delas que ele se comunica e constrói significados pessoais para o mundo interno e externo. Dessa maneira, pode-se entender a linguagem em suas inúmeras formas: verbal, visual, artística, corporal, musical, científica, entre muitas outras. Uma das tarefas da educação é tornar o indivíduo "falante" em cada uma delas de maneira adequada para o seu desenvolvimento. Aprofundar-se no conhecimento dessas linguagens é proporcionar ao sujeito a melhor compreensão tanto de si próprio quanto do mundo ao seu redor.

Em seu histórico, segundo um documento da instituição registrado como Programa de Inclusão Escolar, datado do ano de 2010, a escola sempre esteve aberta para receber alunos que apresentassem necessidades educacionais especiais. No entanto, o trabalho ficava restrito à coordenação, diretamente ligada à série a qual a criança pertencia e à professora da criança.

Foi somente a partir do ano 2008 que a escola se propôs a pensar e a se aprofundar nas questões relacionadas à inclusão. Neste ano, criou-se um grupo de estudos sobre inclusão escolar, que permanece até os dias atuais, a partir de uma demanda que cresceu e se tornou evidente, sobretudo, por parte dos educadores.

A partir da iniciativa do grupo de estudos, a escola começou a pensar a inclusão de maneira mais aprofundada. No ano de 2010, criou e desenvolveu o Programa de Inclusão Escolar, com o objetivo de que todas as reflexões, adaptações e exercícios da prática educativa com seus alunos sejam pensados coletivamente. É 
coordenado por uma professora de apoio de inclusão ${ }^{19}$, do qual fazem parte alguns dispositivos: reuniões coletivas semanais no período escolar entre os professores que possuem crianças em situação de inclusão em seus grupos com objetivo trocar as práticas educacionais; observação das crianças em situação de inclusão em diversos momentos da rotina com o objetivo de refletir sobre os encaminhamentos e ações a serem oferecidos; acompanhamento pedagógico ${ }^{20}$ — inspirado no trabalho de acompanhamento terapêutico - trabalho exercido pelos professores da própria escola que exercem um trabalho de acompanhamento da criança dentro do contexto escolar com diferentes metas e propostas, de acordo com a necessidade de cada criança; monitor pedagógico, função criada no ano de 2011, no qual um educador fica disponível, fora dos espaços de sala de aula, para se relacionar com as crianças que por diferentes razões não permanecem dentro de suas salas durante todo o período escolar.

A unidade da educação infantil recebe crianças de um a seis anos, uma vez que o primeiro ano do Ensino Fundamental encontra-se alojado no prédio dessa unidade. Contudo, para a pesquisa, contaremos apenas com as séries que se referem à Educação Infantil, ou seja, crianças de um a cinco anos e onze meses. Nesse contexto, no momento da pesquisa a escola contava com 522 alunos na Educação Infantil. Cada série tem em média três grupos por período, à exceção da série das crianças de um a dois anos, composta por dois grupos por período. Cada grupo tem em média vinte crianças, podendo variar até vinte e duas crianças por classe.

No momento da pesquisa a equipe pedagógica da escola era composta por 37 professores, 36 professores auxiliares, uma professora de apoio de inclusão, cinco coordenadoras - uma para cada série, sendo que uma delas coordena duas séries duas coordenadoras gerais - divididas entre Infantil I (de um a três anos) e Infantil II (de quatro a seis anos), três coordenadores de área - música, corpo e movimento, educação ambiental e artes visuais - e duas diretoras.

Nesse período, a escola contava com quinze crianças em situação de inclusão. Destas, sete recebem acompanhamento pedagógico que foram oferecidos após a

\footnotetext{
${ }^{19}$ Nomenclatura interna da instituição.

${ }^{20}$ Os acompanhantes pedagógicos, chamados Aps, são indicados pela escola às famílias cujos filhos necessitam de um trabalho mais individualizado. Contudo, mesmo sendo um dispositivo oferecido pela própria escola, a família paga à parte por esse trabalho. Ou seja, têm um acréscimo nas mensalidades de seus filhos.
} 
análise de cada caso, de acordo com as necessidades particulares de cada criança e cada um destes acompanhamentos possui metas e estruturas diferentes.

Tendo em vista os objetivos deste trabalho, foram propostas de início algumas delimitações para a coleta de dados que poderiam vir a ser transformadas ao longo do percurso, caso necessário. Optamos por colher depoimentos individuais dos professores que tivessem em sua sala de aula crianças em situação de inclusão que estivessem, ao menos, em seu segundo ano escolar (que estivessem frequentando essa escola há no mínimo um ano), e que tivessem entre três e seis anos de idade. A delimitação proposta partiu de alguns pressupostos: o primeiro, parte do princípio de que para que a criança tenha um histórico escolar é necessário que ela já tenha um percurso dentro desta escola e o tempo considerado pela própria instituição é de no mínimo um ano letivo. O segundo, da demarcação da faixa etária, refere-se ao fato de que nessa instituição não havia crianças com idade inferior aos três anos consideradas em situação de inclusão até o momento do início da pesquisa.

Portanto, dentro dessa delimitação encontramos quatro educadoras que se dispuseram a participar da pesquisa para relatar suas experiências com seus respectivos alunos ${ }^{21}$. Os relatos foram fornecidos por Ana, professora de Luis Felipe de cinco anos e meio e de Carolina com seis anos e meio; Renata, professora de Caio com cinco anos e meio; Luciana, professora de Pedro com 4 anos e meio e Andrea, professora de Antonio de quatro anos e meio. A participação na pesquisa foi voluntária e a possibilidade dos educadores contribuírem ou não com a investigação bem como a possibilidade de desistirem da pesquisa esteve, desde sempre, aberta. Baseada nesta contigência, a participante Andrea pediu que a pesquisadora retirasse sua entrevista da pesquisa, sem fornecer maiores argumentos a esse repeito. O pedido foi atendido e, por conseguinte, apresentaremos apenas quatro entrevistas cedidas por três educadoras da escola pesquisada.

\subsection{Entrevistas I}

Antes da apresentação os relatos colhidos na escola, será feito um breve recorrido da caracterização escolar do histórico das crianças, com base nos registros escolares feitos pelos educadores que as acompanharam até o momento da pesquisa, a

\footnotetext{
${ }^{21}$ Todos os nomes atribuídos às crianças e aos adultos nos recortes apresentados são fíctícios, em conformidade com o código de ética no que diz respeito à preservação da identidade dos sujeitos.
} 
fim de situar seus percursos nessa instituição. Essas informações só foram obtidas pelo fato da pesquisadora fazer parte do quadro institucional e ter acesso direto a tais elementos.

\section{2.a Luís Felipe}

Ana, 29 anos, psicóloga e pedagoga é professora de Luís, cinco anos e sete meses, que entrou na escola no início de 2010 com o semestre letivo já em andamento. Em sua primeira visita à escola, notou-se uma significativa falta de limites ao não atender às regras apresentadas pela educadora que passeava com ele pelo espaço, além de se colocar em risco (e às outras crianças também) ao tentar descer de uma alta escada, que levava à casa da árvore, pisando nas crianças que nela tentavam subir. Frente a isso, em seu primeiro dia de aula, a escola disponibilizou um educador a mais na sala de aula para ajudar os professores, o grupo e Luís no processo de adaptação.

Nesse primeiro ano escolar, ficou acordado entre a escola e a família que Luís precisava de um acompanhamento pedagógico que pudesse ajudá-lo a se inserir no grupo e a se relacionar com as crianças. Luís mal entrava na sala de aula. Buscava lugares periféricos e os adultos que não eram os educadores oficiais da escola, mas equipes da manutenção, da informática e da limpeza. Eram esses os seus interesses. Sua fala elaborada e recheada de rico vocabulário ficava presa aos instrumentos utilizados por esses adultos, sem fazer ou procurar saber sobre o uso deles. O contato com outras crianças era quase nulo, e ocorria apenas quando Luís os mordia, fato que acontecia também com os educadores da escola. Quando precisava ir o banheiro, dificilmente usava o vaso sanitário, fazendo suas necessidades no chão ou no quintal da escola. Frente a esse cenário, a instituição optou por dar ênfase no processo de adaptação de Luís à escola, na possibilidade de construção de relações sociais e nas brincadeiras, deixando para um segundo plano a sua integração ao grupo e às demandas de escolarização. Antes do encerramento do ano letivo, os profissionais da escola, a psicanalista que o atendia e a família decidiram diminuir o período diário de Luís na escola, após constatarem que a última hora do seu período escolar era o momento em que ele acabava machucando outras crianças, e promovendo atos que não eram permitidos na instituição. Dessa maneira, Luís terminou o ano permanecendo na escola uma hora a menos do que os outros alunos. 
O segundo ano, 2011, começou parecido com o final do primeiro: mordia e cuspia nas pessoas além de urinar pelo chão da escola. Apesar de ser uma nova sala de aula e novas professoras, Luís já dominava bastante o espaço escolar, então foi decidido que o foco seria nas relações sociais dentro do grupo, com limites e formalização de procedimentos.

A partir da fala enunciada pela professora Ana, podemos identificar que a posição de Luís na estrutura discursiva da escola era um lugar "de fora" uma vez que a referência era sua sala de aula, do grupo ao qual pertence, ou deveria pertencer, devido ao fato de estar matriculado nessa escola e nesse grupo.

"Era uma criança que se relacionava só com os adultos da escola, tinha uma fala muito elaborada com os adultos, mas que na hora de falar com as crianças, era uma relação muito primitiva, muito diferente."

"Era uma criança que... é meio feio falar, mas eu vou fazer uma metáfora, entre aspas Ele parecia um "bichinho", uma criança muito arredia, de difícil contato, difícil nas relações. Ficava muito fora, estava parecendo um outro lugar, outro momento, muito distante da realidade das crianças do grupo."

"Eu acho que assim, o Luís, quando ele entrou o ano passado na escola, que eu falo que ele parecia um bichinho, e que no começo desse ano ele ainda tinha muito dessa característica, eu acho que ele precisou de um tempo na escola para conhecer esse espaço como um todo, para conhecer os adultos em geral. Ele precisava de um tempo dele para se relacionar com esse espaço e com essas pessoas, de um outro jeito que não era esse que a gente fala hoje."

Tomando esse discurso a respeito do lugar de Luís na escola, é possível dizer que o discurso corrente na instituição, enuncia-se a partir do discurso do mestre, aquele que somente quer que as coisas funcionem sem saber nada sobre a verdade. Portanto, o que devia ser feito com Luís no momento de sua entrada na escola: conhecer a escola, conhecer os adultos, se relacionar com o espaço, para que após esse momento ele pudesse ser inserido no grupo, na rotina escolar e estabelecer relações com as crianças. Afinal, existe um saber sobre como proceder com o trabalho de inclusão escolar de uma criança, que prega como objetivo a sua inserção no grupo e na rotina da escola.

Em toda estrutura discursiva temos os lugares:

$$
\frac{\text { agente }}{\text { verdade }} \rightarrow \frac{\text { outro }}{\text { produção }}
$$


Se o que estava em jogo no discurso da instituição é o discurso do mestre:

$$
\frac{\mathrm{S} 1}{\$} \rightarrow \frac{\mathrm{S} 2}{a} \quad \frac{\text { A inclusão de Luís deve ocorrer }}{\text { Não há garantia de incluir }} \rightarrow \frac{\text { Os manuais e a psicanálise sabem disso }}{\text { Luís não está inserido no grupo }}
$$

O trabalho que devia ser feito com Luís era o de inserção, de pertencimento ao grupo, de inclusão escolar. Apesar da permissão corrente de que ele precisava de espaço para conhecer a escola e com ela se relacionar, havia uma exigência de que ele pertencesse ao grupo, de que correspondesse às expectativas como acontecia com os demais alunos. Essa exigência estava, inevitavelmente, fadada ao fracasso uma vez que esta formação discursiva colocava Luís no lugar de objeto - esvaziado de sua subjetividade - , pregando a existência de um saber sobre o objetivo de trabalhar com a inclusão: inserir a criança no grupo. Entretanto, esbarrava na impossibilidade de Luís corresponder com tais expectativas.

Mas qual era o lugar ocupado por Luís? De que lugar ele agenciava o seu discurso? Tais perguntas nos levam para um outro caminho que não cabe responder neste trabalho que tem como foco o discurso dos educadores. No entanto, podemos levar em consideração que, de certa forma, ao não corresponder com o que era esperado pelo discurso do mestre corrente - a inclusão - Luís evidenciava a incompletude e a fragilidade desse discurso, tal como faz a histérica que precisa de um mestre sobre o qual ela reine e ele não governe, impelindo, consequentemente, a produção de saber.

"Era uma criança que demandava praticamente uma atenção individualizada de um adulto. Era uma criança que não conseguia muito ficar no grupo, uma criança que ficava muito tempo fora, no quintal, nas outras salas... Tinha uma circulação muito grande na escola, nos espaços... tinha uma coisa, uma agitação, uma coisa física, corporal de não conseguir se conter muito dentro, sentado, sentar para fazer uma atividade, sentar e fazer uma roda... Eram coisas praticamente impossíveis no começo do ano."

"Então, quando ele estava aqui na sala às vezes acontecia uma mordida, ou puxava o cabelo do amigo, ou dava uma cuspida ou jogava água (...) então, não era só um processo dele, mas era dele que envolvia todo um entorno. Então por isso que o trabalho era cansativo."

No lugar de agente e porta-voz dos conhecimentos politico-partidários que envolvem a prática da inclusão escolar, Ana agencia o discurso do lugar de S1 dirigindo-se a S2, o saber dos manuais que definem como proceder nos processos 
inclusivos. Essa enunciação só fez produzir um aluno subversivo, $a$, que não corresponde ao resultado esperado de inserção escolar, e que não aceita a condição de ser apenas objeto. Ele devolve essa não-correspondência no lugar da verdade, $\$$, em relação à sua subjetividade que não pôde ser levada em conta. O que Ana recebia, nessa estrutura discursiva era a impossibilidade da inclusão de Luís se efetivar além de um trabalho cansativo que não chegava jamais ao seu fim.

Ao não se prestar a ocupar o lugar de objeto, Luís permitiu que Ana fizesse um giro em sua produção discursiva, se lançando a agenciar um novo discurso, na tentativa de produzir algo novo. Nesse quarto de torção temos, então, a emergência do discurso da histérica:

$$
\underline{\$} \rightarrow \frac{\mathrm{S} 1}{\mathrm{~S} 2}
$$

$\frac{\text { Não sabemos o que fazer com Luís }}{\text { Não adianta impor a inclusão }} \rightarrow \frac{\text { Alguém deve saber }}{\text { Buscam-se respostas }}$

Vemos a instalação do discurso da histérica no momento em que Ana parece denunciar a improcedência da imposição da inclusão. Enunciando a partir do lugar de sujeito barrado (\$), ela desestabiliza e provoca questionamentos para o sujeito. Nesse momento o saber (S2) não está mais ao seu lado, ela produz um saber que ela própria desconhece e não sabe o que poderá fazer com ele.

Desse modo, no relato da professora é possível identificar os momentos de passagem de um discurso ao outro e a chance de que se gerem efeitos na posição discursiva ocupada pela criança. É interessante perceber que ao tornar evidente o furo do discurso do mestre que imperava na instituição, um giro discursivo ocorre e Ana passa a agenciar a partir do discurso da histérica.

Vemos ocorrer aqui um giro discursivo, uma transformação da queixa -, questionamento queixoso que apenas seguia o que deveria ser feito - em enigma um novo questionamento que permitiu a construção de um saber inédito. Da queixa em relação o que devia ser feito em relação ao processo inclusivo de Luís, a educadora passou a se questionar sobre o que fazer com Luís, questionamentos que foram colocados em ato. Segundo Voltolini (2001), é a partir de questões que pode se dar

a construção de um saber inédito (S2), que faz efeito de mudança subjetiva porque não é erudito. Não surge para reger uma prática, mas para liberar um ato. (Voltolini, 2001, p. 110) 
Entretanto, ao impelir saberes os quais desconhecia e ao se deparar com nenhuma resposta sobre como proceder com seu aluno, vemos a educadora se lançar num desafio, tendo de elaborar um saber próprio a respeito de sua realidade educacional. Tal constatação promove um novo giro discursivo, no qual Ana volta a agenciar a partir do discurso do mestre, não mais colocando o saber nos manuais, mas no aprendizado diário com o próprio Luís, sendo considerado agora, em sua singularidade.

"(...) eu acho que o que começou a mudar este ano foi ter um investimento do Luís para dentro.(...). Então, a gente começou a passar isso para ele: 'o que será que você já dá conta, olha o que você está fazendo', a colocá-lo nesse grupo. 'Olha o que seus amigos estão fazendo', a inseri-lo muito nesse contexto".

"Foi uma decisão que a gente foi impondo. Eu acho que se a gente não tivesse sido firme em alguns momentos, bancado algumas atitudes, apostado em outras como: 'eu quero que ele participe dessa roda, acho que vai ser importante para ele. Eu quero ele aqui', então, (a gente) fazia um superesforço para manter o menino na roda, e ele cantando, fazendo mil barulhos, (...) e as crianças: 'ai, o Luís está atrapalhando' e a gente: 'calma, gente, mais um pouco, espera aí... ele vai só beber uma águinha e vai se acalmar'."

A partir desses fragmentos vemos a professora sair da posição de agente do discurso da histérica e se pôr no lugar de agente do discurso do mestre, que quer que as coisas funcionem, sem nada saber sobre a verdade. Nessa dinâmica de deslizamento discursivo, há a passagem de um discurso ao outro. Nesse sentido, por mais que Ana agencie seu discurso através do discurso do mestre, no momento da passagem não podemos descartar o manejo do discurso do analista, discurso que considera o outro como sujeito.

Vemos que na dinâmica do giro discursivo, a professora não enuncia a partir do lugar de agente do discurso do analista. Contudo, sabe-se que o analista só assume seu lugar através de seu ato, o ato analítico, que como todo ato tem a direção do Real. Ao contrário dos outros discursos, nos quais é possível estar na posição de agente, ou seja, permanecer no Real, pelo discurso do analista só se pode passar.

Silveira (2011) ressalta que Lacan em seu seminário 20, Mais ainda (1972/1973), afirma que sempre que há mudança de discurso, há uma passagem pelo discurso do analista, o que equivale dizer que só se muda de discurso ao se confrontar com o Real. O discurso do analista é então um discurso de passagem para os outros discursos. 
Pode-se dizer que Ana, no ato da mudança de sua posição discursiva, passou pelo discurso do analista, que nessa ordenação, demonstrou a impossibilidade de fazer da inclusão um imperativo a despeito da singularidade das características de Luís. Ao se deparar com o impossível de Luís assumir a condição de objeto e corresponder com o que se esperava dele: inserir-se no grupo, Ana questiona os manuais que aparentavam deter o saber de como proceder com a inclusão. Frente a isso, ela tenta produzir algo diferente. Reconhece que Luís não é um mero objeto e sim alguém que do ponto de vista psicanalítico pode ser considerado, em alguma medida, como desejante. Portanto, assume a posição dominante do discurso do mestre, na busca de uma nova produção. E encontra:

\footnotetext{
"Hoje é uma criança que está superinteressada pelo que está acontecendo aqui dentro, é uma criança que não circula mais tanto quanto circulava antes. Ele pode também descobrir e achar os interesses dele dentro desse grupo, junto com essas crianças (...). E hoje a gente percebe ele na roda, levanta a mão para falar, e fala coisas coerentes, coisas que têm tudo a ver com o que a gente está falando, se coloca e se posiciona com os amigos de um outro jeito."
}

Pereira (2005) ressalta a importância de o docente operar no discurso do mestre - princípio de todo discurso dos professores por sempre inaugurar o significante primeiro $(\mathrm{S} 1 \rightarrow \mathrm{S} 2)$, traço de lei — para não se reconhecer nele. Ele deve utilizar-se do discurso do mestre para não permanecer ali, uma vez que esse discurso faz tudo submeter-se à lei e não admite qualquer tipo de falta. $\mathrm{O}$ autor ainda faz uma importante ressalva em relação ao aluno desviante - aquele que não corresponde às condutas escolares:

Qualquer sujeito desviante em condutas escolares, a exemplo de um delinquente, demanda um mestre que o interdite, sob o prisma da lei simbólica e não da regra tomada na sua inscrição imaginária. Desviados, loucos, crianças violentas, todos querem se fazer sujeitos. Eles e elas exigem e aspiram o simbólico que os cale o imaginário. Esperam que o outro invente o caminho, que dê o primeiro passo para que o convide a dar o seguinte. Cada um dos desviados, por mais que desenhe as experiências pedagógicas, demanda que se invente outra coisa capaz de intervir em seus efeitos de gozo. (Pereira, 2005, p. 111).

Portanto, cabe ao educador oferecer, em ato, a ferramenta para que seus alunos sejam considerados como desejantes. No caso de Luís, Ana enquanto sua professora mudou as atitudes anteriormente assumidas em relação a ele. Da permissão para estar fora do grupo, passou a dar ênfase na sua permanência dentro, na importância que 
tinha a sua presença no grupo, apostando que, naquele momento, essa era a melhor conduta a ser tomada. Ana precisou assumir o discurso do mestre para interditar Luís em seu gozo, trazendo a regra sob a perspectiva simbólica, aumentando a chance de sua emergência como um sujeito pertencente ao grupo escolar.

Esse ato educativo foi marcado pelo esvaziamento do mestre como inflação imaginária, reconvocando-o como lei simbólica. Houve uma giração dos discursos que produziu efeitos consideráveis, e não apenas um deslocamento para o discurso do mestre que impôs cegamente as regras a serem seguidas. A lei simbólica trazida para o ato educativo promovido por Ana, apostou em Luís considerando-o em sua singularidade.

\footnotetext{
“Acho que essas apostas foram imprescindíveis. Se a gente não acreditasse nisso, se a gente pensasse: 'ah não, nada a ver ele estar aqui, ele está atrapalhando, realmente não quero que ele fique aqui', ele ia ficar lá fora, não ia atrapalhar, mas ele também não ia se envolver. Ele não ia se ver parte desse grupo, então eu acho que isso fez muita diferença”.

"A coisa do corporal hoje se aquietou. Hoje senta, faz duas lições seguidas e tem vontade de fazer, ele pede para fazer: 'hoje eu tenho lição? Hoje eu quero fazer, hoje eu quero ir nesse canto, hoje eu quero ir no atelier...', o quanto ele pôde descobrir uma outra escola que eu acho que ele não conhecia no começo do ano."
}

Parece que Ana demonstrou não se fixar em normas e técnicas decorrentes de qualquer forma de autoritarismo oriundo da lógica imaginária para interditar os atos inadequados de Luís. Ao contrário, fez uso desses instrumentos para ultrapassá-los. Recurso inventivo e autoral que depôs o imaginário, onde impera o apagamento da diferença e, portanto, da singularidade em função do que era idealizado.. Ana não buscou fazer com que Luís se reduzisse a cumprir com as premissas escolares que abusam do ordenamento e da moralidade. Em relação aos ganhos cognitivos de Luís, Ana deixa bem clara a sua posição:

"No começo do ano isso não era uma preocupação que eu tinha. No tempo que eu
tinha com o Luís dentro da sala, não era uma preocupação que eu tinha de trabalhar
letras e números com ele. O que tempo que eu tinha dentro da sala, eu queria
inserir ele no contexto, ou das crianças ou do trabalho. Não me preocupava em tirar
ele para ver se ele estava conhecendo os números e as letras (....)."

É possível levar em conta que o giro discursivo promovido na educadora, que a levou a declinar-se da mestria como imagem e restituí-la como o simbólico, ou seja, a 
instância da lei, gerou efeitos significativos em Luís. O fato de a criança não ter assumido o lugar que lhe era designado anteriormente no discurso institucional (o de objeto a ser incluído) gerou efeitos significativos na posição da educadora. De petrificada na impossibilidade de Luís não estar incluído, passou a se questionar sobre o que fazer com ele. Consequentemente, Luís passou a ser reconhecido como uma criança singular. Os fatores acima citados, efeitos dos giros discursivos podem ser considerados indicadores de sucesso do processo inclusivo de Luís.

Em relação aos suportes oferecidos pela instituição na contribuição do trabalho com a inclusão escolar, Ana aponta para alguns dispositivos que considera essenciais para a condução desse processo. Um deles é a reunião coletiva que ocorre semanalmente dentro do período escolar com a participação dos professores, professores auxiliares e acompanhantes pedagógicos que trabalham diretamente com as crianças em situação de inclusão, com o objetivo de compartilhar suas práticas cotidianas e suas dúvidas.

"Então em 2010 começou a funcionar na escola um horário dentro do período em que os professores podiam ir numa sala e discutir sobre essas crianças, junto com uma professora de apoio de inclusão que tinha essa função para ajudar no trabalho com elas. (...) Isso eu acho que é uma mudança muito grande e traz um alívio muito grande para os professores que participam deste trabalho, porque ao mesmo tempo em que é um trabalho (...) lento, precisa de muito investimento... então, você ter um espaço para dividir essas angústias, poder ouvir outras ideias, sugestões... nossa, isso me ajudou muito!".

Essa fala de Ana evidencia que um dos dispositivos oferecidos pela instituição que visa o suporte para o trabalho com a inclusão vai ao encontro das ideias apontadas por Bastos (2003) e Prioste (2006) sobre a importância de se ter na instituição um espaço de escuta e troca entre os professores com o objetivo de acolher angústias decorrentes do cotidiano escolar, permitindo a emergência do conflito para pensar a relação com o aluno em sua singularidade e promover novas saídas para o dia-a-dia com as crianças em situação de inclusão. Não foi possível identificar no relato de Ana se a mudança de atitude em relação a Luís decorreu das discussões promovidas nesses encontros internos, mas é possível levar em conta que a existência deste espaço pôde contribuir para o trabalho com essa criança quando Ana revela que as produções desses encontros ajudaram-na significativamente.

Para finalizar, apresentamos um recorte da fala de Ana bastante significativo que ilustra a mudança de posição discursiva assumida por Luís. Inicialmente colocado 
na posição de quem estava constantemente "fora" para a posição de uma criança pertencente, curiosa e pertinente:

\begin{abstract}
Então, por exemplo, hoje, aconteceu uma cena que eu achei muito engraçada: ele estava falando, dando dicas. A gente estava conversando de plantas, dos cuidados e aí, ele levanta a mão e fala assim: 'eu pensei numa coisa que a gente podia fazer umas placas e colocar no quintal que não pode machucar as plantas e que precisa cuidar...'. Superbonitinho e outra criança começou a falar junto com ele e aí eu falei para essa outra criança: 'Fran, você não está ouvindo? O Luís está falando, você está atrapalhando'. Aí o Luís olhou pro Fran e disse: 'Chato Fran, agora eu tô falando'. Então, nisso, nessas colocações a gente vê como ele se aprimorou nessas coisas, da relação, dessas condutas mais adequadas, a gente vê que hoje ele é uma criança muito perto das outras do grupo.
\end{abstract}

Isso nos autoriza a pensar que o trabalho dessa professora e os efeitos decorrentes dos giros discursivos contribuíram para que a criança pudesse ocupar uma nova posição na estrutura discursiva da escola. De acordo com os fatos apresentados e analisados, tal mudança ocorreu porque Luís passou a ser valorizado em sua singularidade. De "bichinho" passou a ter atitudes "muito próximas dos alunos de seu grupo". Reconhecimento que surgiu em decorrência dos indicadores encontrados no relato de Ana e de alguns dispositivos oferecidos pela instituição para dar suporte à educação inclusiva, baseados na discussão e reflexão da prática educativa singular com essa criança.

\title{
7.2.b Carolina
}

Ana é professora de um grupo no qual havia duas crianças que a escola considerava em situação de inclusão. Além de Luís, Ana teve Carolina como aluna, uma menina de seis anos e meio com síndrome de Down. Carolina entrou na escola por volta dos dois anos de idade, frequentou o equivalente ao G2, passou ao G3 no ano de 2008 e em meados deste ano, sua família mudou-se do país, retornando ao Brasil e à escola no início de 2009. Nessa volta, a família optou por Carolina voltar para o G3, inicando o ano com um grupo novo de crianças e professoras, mas que oferecesse desafios que estivessem mais adequados à sua condição naquele momento. Desse modo, Carolina estava um ano atrasada em relação à faixa etária, tornando-se então a criança mais velha do grupo.

Em 2010 ela passou para o G4 e em 2011 para o G5, ano no qual a entrevista com Ana foi realizada. Veremos no discurso da educadora as atitudes assumidas pela instituição em relação ao trabalho desenvolvido com Carolina, bem como algumas 
conquistas decorrentes das mudanças de atitudes, de olhar e de práticas em relação à criança. No discurso da educadora também é possível identificar o lugar de Carolina na estrutura discursiva institucional, o de uma menina tranquila e que estava sempre presente no grupo.

"Ela é uma menina que tem um diagnóstico, e tem uma coisa física e genética, é uma criança com síndrome de Down, que até o momento (em que Ana recebeu Carolina como aluna) a escola não tinha sentido a necessidade de ter um acompanhamento pedagógico para ela. E eu, entendo perfeitamente essa posição da escola, porque é uma criança que realmente não dava trabalho no grupo."

"Diferente desse menino de inclusão (que está na mesma sala) e de outras crianças da sala que não eram de inclusão, Carol era uma menina que... se era roda ela sentava e fazia roda, se era atividade ela sentava e fazia atividade, se era lição ela sentava e fazia lição. Era uma menina tranquila e que estava ali presente o tempo inteiro, não incomodava ninguém... então, né, acabava passando meio despercebida."

"E foi esse o nosso medo justamente de... putz, a gente tem o Luís que demanda um supertrabalho, um superinvestimento e por outro lado a gente tem a Carol, que é uma criança com síndrome de Down que também precisa de uma atenção especial, mas como ela está ali tranquila, se vira bem sozinha, não precisa de alguém para ela, ela vai indo, ela vai ficando".

Ana revela que o fato de Carolina estar aparentemente incluída no grupo por estar frequentemente de "corpo presente" nas propostas grupais, trazia uma certa despreocupação com o seu acompanhamento individual. A professora deixa clara a forma como Carolina se apresentava no grupo: o de uma menina presente e, portanto, incluída do ponto de vista institucional.

O que temos até aqui é um cenário de um aparente sucesso em relação a este processo inclusivo, uma vez que Carolina estava constantemente presente, acompanhando o movimento das crianças e sem "dar trabalho" e atrapalhar o adamento grupal. Até esse momento, parecia que o imperativo da inclusão estava sendo cumprido: Carolina estava incluída no grupo. $\mathrm{O}$ discurso do mestre institucional de a inclusão ocorra, parecia ter tudo sob controle.

$\frac{\mathrm{S} 1}{\$} \rightarrow \frac{\mathrm{S} 2}{a \text { Carol acabava passando meio despercebida } \quad \text { Carolina fica dentro da sala e no grupo }} \rightarrow$ Professores conseguem mantê-la inserida no grupo

Contudo, como veremos a seguir, o fato de estar presente - e de não atrapalhar o grupo, conforme a fala de Ana - foi uma das características que chamou 
a atenção da instituição para pensar em um trabalho específico para ela. Parece que aqui houve uma espécie de confrontação de Ana com o seu próprio dizer, uma vez que ao afirmar que Carolina estava incluída e tranquila no grupo, ela se depara com um atraso cognitivo relevante que a faz repensar sobre a real inclusão de Carolina. Estamos chamando aqui por confrontação aquilo que Lacan (1958) marcou e distinguiu de uma interpretação.

Nas palavras de Lacan (1958):

O procedimento torna-se revelador quando se aproxima do centro de interesse. (...) uma formulação articulada para levar o sujeito a ter uma visão (insight) de uma de suas condutas (...) possa receber um nome totalmente diferente, como confrontação, por exemplo, nem que seja a do sujeito com o seu próprio dizer, sem merecer o de interpretação, simplesmente por ser um dizer esclarecedor. (Lacan, 1958, p. 598).

Parece que no momento em que ocorre essa espécie de confrontação da educadora com o seu próprio dizer (ou até mesmo com sua prática educativa) abre-se a possibilidade para que ela se dê conta de sua implicação no trabalho com Carolina e possa, a partr daí, pensar em novas práticas dirigidas a ela.

É provável que o investimento primeiro tenha sido com Luís, que demandava um trabalho muito mais exaustivo e intenso, e somente depois que o trabalho com ele já estava encaminhado é que os olhares puderam se voltar para Carolina. E um início de reflexão pôde emergir:

"E eles são de um grupo que aqui na escola são crianças de 5 para 6 anos, a Carolina é uma menina que já teria idade para estar num grupo acima, ela já fez seis anos no primeiro semestre, e é uma das mais velhas... não, é a mais velha do grupo. E a gente começou a pensar: puxa, ela já tem seis anos e o quanto a gente está podendo investir nessa menina".

A partir do momento no qual algumas constatações sobre as dificuldades de Carolina tornaram-se bastante evidentes e o seu atraso cognitivo em relação ao grupo ficou muito mais claro, Ana passa a se questinar sobre o que estava podendo oferecer à criança, dado que, aparentemente, Carolina estava incluída. Parece que ao deixar evidente o seu atraso cognitivo, Carol revela a impossibilidade de continuar assumindo o lugar que, até então, lhe era designado no discurso: o de criança incluída.

"Então, ela não reconhecia o nome, não escrevia e a gente começou a perceber que ela também precisava de muito investimento, num outro sentido, e ela também precisava de uma atenção especial, que só as duas professoras do grupo, eu e a 
auxiliar, não estávamos dando conta”.

Apesar de Carolina acompanhar fisicamente o grupo, houve um momento no qual as dificuldades tornam-se patentes e passaram a "saltar aos olhos". De uma criança tranquila e que não dava trabalho, ela passou a ficar muito atrasada no que tangia aos conteúdos pedagógicos em relação ao grupo ao qual pertencia. Parece que somente quando o atraso cognitivo tornou-se evidente é que diferentes reflexões e práticas passam a acontecer em relação à criança. De certo modo, parece que algo particular do caso em questão tornou-se evidente, revelando uma impossibilidade do imperativo da inclusão ocorrer o que levou a uma fratura do processo da mestria institutional corrente.

Ao não se prestar a ocupar o lugar de objeto, Carolina permitiu que Ana fizesse um giro em sua produção discursiva, na qual passa a agenciar um novo discurso na busca de produzir algo diferente. Nesse quarto de torção, tem-se a emergência do discurso da histérica:

$\frac{\$}{a} \rightarrow \frac{\mathrm{S} 1}{\mathrm{~S} 2} \quad \frac{\text { Não sabemos mais o que fazer com Carolina }}{\text { Não adianta impor a inclusão }} \rightarrow \underset{\text { Alguém deve saber }}{\text { Buscam-se respostas }}$

Vemos a ocorrência da instalação do discurso da histérica no momento em que Ana parece denunciar a improcedência da inclusão de Carolina, dado que apenas estar presente no grupo não mais caracterizava a sua inclusão. Enunciando a partir do lugar de sujeito barrado (\$), ela desestabiliza e provoca questionamentos para o sujeito. Nesse momento o saber (S2) não está mais ao seu lado, ela produz um saber que ela própria desconhece: buscar novas maneiras de ajudar Carolina na escola. $\mathrm{Na}$ instalação do discurso da histérica, Ana vai em busca de respostas e saberes nos suportes oferecidos pela instituição (ajuda da coordenação) pois é no reconhecimento desta espécie de falha no processo da inclusão de Carolina, que algo novo pôde emergir.

Ao constatar as dificuldades da criança, ao invés de paralisar o investimento em seu processo inclusivo, Ana demonstra que com a ajuda da instituição, chegou-se a alguns caminhos possíveis para ajudá-la, entre eles a inserção de mais um adulto que pudesse atuar em conjunto com os professores no processo de inclusão de Carolina, como um dispositivo, chamado pela escola de acompanhamento pedagógico.

No momento em que Carolina passa a não responder mais do lugar o qual the 
era designado no discurso institucional, o de uma criança incluída, Ana passa a se questionar sobre o efetivo trabalho inclusivo que estava sendo feito com ela.

"E daí começou a se pensar num acompanhamento para ela e assim foi feito. Então temos agora uma pessoa que vem acompanhar a Carol, algumas vezes por semana. E eu acho também que foi essencial. Pensando na Carol no começo do ano... bom, a gente tem aqui na escola algumas avaliações, lições que a gente repete no começo do ano, no meio e no final, para ver o que a criança avançou: de desenho, escrita, de matemática, de recorte, corporalmente também, então a gente vai olhar por vários aspectos. E a Carol é uma criança que a gente percebe o quanto avançou, e muito desse avanço a gente tem graças à possibilidade de ter um acompanhamento para ela".

"A Carol, no começo do ano, apesar de ela ficar e participar de tudo, por exemplo roda, era uma participação muito... ela estava ali de corpo, né? Mas a gente percebia que ela não estava ali presente de corpo e alma. Ela não estava muito ouvindo o que a gente estava falando. Não por desinteresse dela, não é isso. Acho que às vezes eram rodas muito compridas, e nesse ano isso é uma diferença que marca em relação ao ano passado".

"No começo do ano a gente estudou os planetas, o espaço e as crianças muito envolvidas nesse tema, elas traziam muitas contribuições, livros e às vezes discussão ia muito longe. Coisas muito abstratas (...) e acho que isso era muito distante da realidade dela, não eram coisas palpáveis, concretas, então eu acho que ela se perdia nesse contexto. Eu acho que ela começava ouvindo, a gente percebia que ela falava algumas coisas como: "planeta", a gente estava falando das cores do planeta e ela falava: "vermelho", e aí, conforme a conversa ia avançando, a Carol ia se perdendo".

A mudança ocorrida com a introdução de um adulto parece que veio ajudar a criança a recuperar o atraso que a estava deixando cada vez mais distante do que era oferecido ao grupo. Entretanto, na fala de Ana podemos constatar o cuidado investido em Carolina com o foco não apenas seu pertencimento ao grupo, como, principalmente, em suas ações que pudessem ajudá-la a avançar pedagogicamente.

"E não poder acompanhar isso, acho que também acabava dando uma desmotivada nela em alguns aspectos. E agora, eu ainda vejo dificuldades da Carol, às vezes de participar de algumas conversas, de entender a complexidade das discussões que as outras crianças já conseguem. Eu percebo a Carol tentando, eu vejo ela lutando. No começo ano ela tentava e desistia e aí ia para outro lugar. Ela ia longe. E hoje eu vejo ela tentando acompanhar".

"Um dia a gente estava numa conversa superprofunda de um artista plástico que faz umas coisas bem bacanas e as crianças estavam bem envolvidas, que é o Krajberg, e a gente falando da casa dele, que ele mora na Bahia, mostramos a casa na árvore, e falando da luta dele que é um processo contra o homem e a destruição da natureza, enfim, esse pedaço, para a Carol, pelo que eu estava observando, estava difícil de acompanhar, mas ela pescava algumas coisas da nossa fala e traduzia na vida dela, no quotidiano dela, então ela olhava para aquilo e dizia: 'a praia, a Carol também 
tem casa na praia' . Ela estava inserida de algum jeito, ela estava tentando... ela estava prestando a atenção, ela percebe alguns elementos, ela se reconhece nele e ela...traduz aquilo para a realidade dela, para o contexto que ela consegue acompanhar. Nessas rodas a gente estava falando sobre o desmatamento e ela trouxe a história do pica-pau. Putz, a gente esta falando de árvore e o pica-pau tem a ver, tem ali uma relação, que as vezes para as crianças é distante, a gente tem que dar uma rebolada para mostrar que o que ela está falando... tem algum sentido, para ela".

É possível identificar algumas discrepâncias entre a singularidade de Carolina e a concepção objetalizada que faziam dela. Nesse momento, Ana se vê confrontada com o seu próprio dizer: de que Carolina era uma criança tranquila e que acompanhava o grupo e estava, consequentemente, incluída. Nesses movimentos que se encontram engendrados, temos alguns indícios que apontam para o sucesso do processo de inclusão de Carolina e ocorre uma re-significação do fazer educativo direcionado a ela. Novas e diferentes estratégias são colocadas em prática e a criança passa a demonstrar avanços importantes naquilo que anteriormente não estava caminhando, como temos nas palavras de Lacan (1969-1970, p. ) "se o discurso não gira, range".

"A questão cognitiva, é um avanço bem palpável, mais concreto, a gente hoje vê a Carol escrevendo o nome dela, (...), todas as letras, agora a gente está começando a apresentar outras palavras estáveis, os nomes dos amigos, a questão com os números, esses avanços são coisas bem fáceis de observar. A coisa do desenho, o desenho dela se estruturou bastante, eu vejo a Carol crescendo muito. A Carol escreve com mais autonomia e mais firmeza o nome dela do que o Luís".

Podemos constatar que o processo inclusivo de Carolina estava caminhando para a obtenção de seu sucesso. Vemos que isso ocorreu devido alguns fatores que podemos identificar como indicadores de sucesso da inclusão escolar. Quando os envolvidos no trabalho podem investir no que é possível fazer com a criança em questão, parece que o sucesso é mais facilmente atingível. Ao passo que se permanecem presos no ideal que leva à impossibilidade do trabalho se desenvolver, o processo pode estar fadado ao fracasso.

Contudo, é interessante constatar que as questões relativas às relações sociais de Carolina ficaram elididas do relato de Ana. Não se sabe se foram obliteradas por estarem garantidas, ou seja, por não se apresentarem como obstáculos ao processo inclusivo ou, ao contrário, por justamente denunciarem uma dificuldade deste trabalho. Esse é mais um fator que nos leva a indagar se os índices de fracasso ficam de fora dos relatos e não podem ser comentados por denunciarem a impossibilidade 
de se atingir o sucesso. Essas questões serão retomadas e discutidas mais adiante.

\section{2.c Caio}

Renata, 33 anos, psicóloga e concluindo a graduação em pedagogia, é professora de Caio, cinco anos e meio. Ele entrou na escola em agosto de 2009, no G3, com crianças de três e quatro anos. Nesse semestre escolar, Caio não se comunicava através da fala, mas de gestos ou puxando a mão do adulto até o local onde queria ir ou até o objeto que gostaria de pegar. Nos registros dos professores havia um grande reconhecimento da intenção de Caio em expressar suas vontades em paralelo a uma preocupação em relação a estimulá-lo a tentar expressar-se sem a mediação do adulto. Nesse período, sua grande referência eram as professoras, com as quais ele passava grande parte do dia de mãos dadas.

No ano seguinte, em 2010, ele passou para o G4 com o mesmo grupo de crianças, mas com professoras diferentes. Segundo os registros das novas professoras, durante as primeiras semanas de aula, Caio procurou muito o espaço de sua antiga sala de aula, em busca de alguns brinquedos com os quais gostava muito de brincar: aviões e carrinhos. As professoras, percebendo esse interesse, trouxeram tais objetos para sua sala de aula, com o objetivo de atraí-lo para esse novo espaço e, assim, estabelecer novos vínculos. Durante o primeiro semestre, Caio praticamente não entrava na classe. Ao chegar, sua mãe ajudava-o a levar sua mochila enquanto ele permanecia pelos espaços do quintal. A mochila era o sinal de que Caio estava presente na escola. Suas professoras fizeram inúmeras tentativas de aproximá-lo do grupo e do espaço da sala, mas não conseguiram muitos resultados. Ele só entrava na sala após o momento de recreio, que era seguido pelo ateliê e depois, pela saída. $\mathrm{Na}$ volta das férias, notaram uma diferença em Caio. Ele passou a entrar espontaneamente na sala logo ao chegar à escola. Circulava pelos cantos que ali se dispunham e não procurava mais sair da sala. Aos poucos, passou a observar os jogos que aconteciam entre os meninos do seu grupo, principalmente os jogos com bola, os quais, à distância, imitava os gestos produzidos pelos chutes e pelas comemorações de gol. Atentas a esse movimento, as professoras passaram a propor brincadeiras com todo o grupo, brincadeiras que passaram a ter a participação mais efetiva de Caio. Ele passou a se tornar parte integrante do grupo e fazia questão de estar sempre por perto. No final do ano, suas professoras passaram a desenvolver atividades específicas para 
ele, voltadas para o reconhecimento das crianças do grupo e seus respectivos nomes através de um jogo de memória construído em conjunto com ele.

$\mathrm{O}$ ano de 2011 começou com Caio muito presente na sala, demonstrando ter as crianças de seu grupo como fortes referências, assim como é possível notar nos recortes feitos a partir do relato da professora Renata:

"Tenho um grupo de 17 crianças entre cinco e seis anos e a gente tem uma criança que é considerada, de fato, de inclusão, embora no grupo tenham também outras crianças que foram encaminhadas ou para psicoterapia ou para fono. Mas essa criança que é considerada mesmo de inclusão, ela tem diagnóstico de autismo".

"Então, o Caio está nesse grupo faz dois anos e a gente percebe que ele começou o ano bem... a adaptação dele não foi uma adaptação difícil, ele parecia já ter o espaço da escola como uma grande referência para a vida dele, e os amigos também, então o grupo também era uma referência e isso ajudou bastante na adaptação dele. $\mathrm{O}$ vínculo que ele estabeleceu no começo do ano, comigo e com o outro professor, Rafael, foi um vínculo bem tranquilo".

"O Rafael e eu, a gente começou o ano bem feliz com essa adaptação tranquila que foi. Inclusive, ele (Caio) ficava bastante no grupo, não procurava tanto os espaços externos da sala, então foi tranquilo".

Enquanto descreve Caio, Renata deixa bem clara a maneira como ele se apresentava no coletivo, sendo que uma de suas características, como poderemos verificar mais adiante, foi o que despertou a atenção para se pensar num trabalho mais específico com ele:

"Ele é bem afetivo, é uma criança bem doce, que não tem nenhum comportamento de agressividade, então isso faz com que ele seja uma criança querida pelo grupo. Ele não grita, não machuca, não tem nada nas atitudes dele que incomode os outros. Isso que também é um perigo dele, que é uma coisa boa, que leva ele às vezes para um lugar invisível. Porque, em muitos momentos, ele é tão tranquilo, tão quietinho que, nesses momentos, se a gente não prestar a atenção passa despercebido e aí, o Caio está lá há meia hora e a gente não se deu conta. Então isso é um lado positivo mas que muitas vezes pode ser uma armadilha, vamos dizer assim, onde ele cai no lugar do invisível".

Através da fala de Renata, é possível constatar o cuidado dedicado a Caio em diversos momentos durante este ano escolar. Esse cuidado, afirmado pela professora, evidencia o olhar atento que lhe era dirigido, com o foco em seu pertencimento ao grupo, em sua inclusão:

"A gente teve um cuidado, que eu acho que foi cuidado, porque ele não se comunica bem com a fala. É uma criança que a fala é difícil de compreender e daí a gente tem 
que tomar todo aquele cuidado de não ficar sempre traduzindo, para ele ter aí, de uma tentativa de fala também. Outras crianças do grupo apresentavam algumas questões relacionadas à fala também, então a gente teve uma sacada, que eu achei boa, de ter como tema de estudo a comunicação. Acho que isso ajudou muito ao Caio estar no grupo também. Porque a gente estudou diversas formas de se comunicar e de se expressar, que vão muitas vezes pela via do afeto, do gesto, da expressão. (...) Então, de certa forma a gente estava significando esse jeito do Caio no grupo. Então o gesto dele tinha mais sentido, a partir do momento que a gente estuda que os gestos também eram um jeito de se comunicar".

Até aqui temos o cenário de um processo inclusivo com aspectos relativamente positivos, uma vez que Caio mostrava-se pertencendo ao grupo, tendo as crianças como referência e estava presente nas atividades coletivas propostas ao grupo. $\mathrm{Ou}$ seja, até o momento o imperativo da inclusão parecia estar sendo cumprido. $\mathrm{O}$ discurso do mestre presente na instituição, que tem sob sua perspectiva que a inclusão aconteça, parecia ter tudo sob controle: Caio estava incluído.

No entanto, Renata mostra certo desconforto, o qual nomeia como angústia, pelo fato de Caio estar presente na sala de aula, contudo, invisível e despercebido. É interessante o modo como ela apresenta o fato de ele ser tranquilo como uma armadilha, pois de tranquilo e presente, corria o risco de cair na ausência e na invisibilidade.

$\frac{\mathrm{S} 1}{\$} \rightarrow \frac{\mathrm{S} 2}{a} \frac{\text { A inclusão de Caio deve ocorrer }}{\text { Lugar invisível }} \rightarrow \frac{\text { Professores conseguem mantê-lo inserido no grupo }}{\text { Caio fica dentro da sala e no grupo }}$

Renata relata a dificuldade decorrente da configuração e da dinâmica de seu grupo, que demandava a presença constante dos dois educadores em tempo integral, o que impedia que parte do tempo pudesse ser dedicado a Caio, na tentativa de tirá-lo da invisibilidade. A angústia decorrente do embuste, muito bem colocado pela professora, como veremos a seguir, foi um dos motivos que fez com que os educadores responsáveis por Caio e por seus processos educativos e inclusivos, se reunissem para pensar em possíveis encaminhamentos para o trabalho que estava sendo desenvolvido com ele:

"Acho que pra gente, que está no grupo, e como esse grupo tem uma dinâmica também que é... não sei se a palavra é difícil, mas uma dinâmica que precisa de dois professores, eu e o Rafael temos muita dificuldade (...) de dar conta dele no grupo".

“O Rafael e eu, a gente sentia angústia quando a gente percebia que o Caio não... que 
a gente não conseguia fazê-lo aproveitar aquela atividade, (...). Principalmente no começo, em que o grupo ainda desautorizava muito a gente enquanto professor, então teve toda uma coisa de constituição de grupo, de legitimar a gente enquanto professor, então o começo foi muito difícil nesse sentido. Então, eu acho que tinha uma angústia nossa e uma preocupação e essa sensação do invisível, era muito presente no começo".

“As vezes a gente se olhava e falava: 'Nossa, um dia passou e o Caio... ficou no 'grupo', e foi como eu falei, no começo ele ficava, mas e aí? O que de tudo isso ele aproveitou? $\mathrm{O}$ que tudo isso significou para ele? Então, acho que partiu muito disso. $\mathrm{E}$ a gente teve conversas com a nossa professora de apoio de inclusão e a nossa coordenadora (...). A gente pensou junto que é uma criança que tem muito potencial, que apresentava um potencial e que a gente via muitas possibilidades, mas que a gente realmente não estava conseguindo. (...) A gente acreditou que tinha um trabalho mais efetivo que podia ser feito, isso foi muito importante e foi daí que a gente decidiu. E acho que a gente acertou, porque muitos frutos vieram desse acompanhamento com a Andrea".

Aqui, Renata demonstra que a angústia experienciada por ela e pelo professor auxiliar, Rafael, foi o motor que os fez tentar ir em busca de outras saídas para o trabalho com Caio. Ao invés de paralisarem o investimento nesse processo, através de recursos oferecidos pela instituição - por exemplo as conversas coletivas entre os professores de Caio, a coordenadora e a professora de apoio de inclusão - , pensaram em outros caminhos, entre eles a inserção de mais um adulto que pudesse atuar em conjunto com os professores no processo de inclusão de Caio, como um dispositivo já mencionado anteriormente, chamado de acompanhamento pedagógico.

Contudo, ainda no relato da professora, Caio retorna das férias num movimento diferente do que vinha apresentando até então. Sua presença no grupo, muitas vezes invisível, passa a dar lugar a uma ausência efetiva:

"Ele volta das férias em agosto, nas duas primeiras semanas, muito bem, muito envolvido nas atividades dentro do grupo. Mas depois dessas duas semanas, ele ficou muito tempo fora. A gente tentou, a princípio ser mais rígido (...) Mas a gente estava trabalhando coleções. E para ele isso foi muito difícil. A gente trabalhou conceitos matemáticos, experiências relacionadas à ciência: peso e medida, então eu acho que o conteúdo ficou muito difícil para ele. Mas foi nesse momento que ele começou a explorar e a desejar outros espaços também".

A partir dos fragmentos apresentados até o momento, é possível pensar que Caio passou a ocupar um lugar que revelou o furo no discurso do mestre que the era dirigido, demonstrando que algo não estava funcionando bem. Caio passou a não corresponder mais ao lugar de objeto que lhe era impingido, demonstrando a impossibilidade de assumir o lugar de destinatário (o outro) a que o agente do discurso lhe remetia. 
Diante dessa denúncia, os professores, atentos ao movimento de subjetivação vivido por Caio, fizeram uma leitura de que estar fora do grupo, significava um reconhecimento e uma apropriação de seus próprios desejos.

"Então à medida que ele fica mais fora do grupo, começa a ser um sinal de que ele está mais desejante. Então aparece um Caio com desejo de ir na casa da árvore, com desejo de explorar os outros espaços do quintal, e com isso ele acaba também ampliando as relações dele. Então antes, o grupo, o Rafael e eu, que eram as referências, ele acaba tendo outras referências. O Fábio que é o Monitor Pedagógico que fica no quintal, então ele acaba tendo também bastante vínculo com o Fábio e com a Andrea que é quem faz o acompanhamento pedagógico dele. Então tem uma saída do grupo e tem também uma legitimação dos desejos dele".

Considero importante fazer aqui uma breve digressão a respeito da relação primordial entre um bebê e sua mãe, levando em conta as marcas simbólicas e as apostas atribuídas à criança. Logo ao nascer, o bebê encontra um mundo de linguagem no qual ele é falado por outros desde antes de seu nascimento. Nessa relação, a mãe diante do estrangeiro que é o seu bebê ao nascer, vai aos poucos se aproximando e conhecendo-o, enquanto este também vai se deixando conhecer. Nesse jogo de conhecimento e aproximação mútuos, há nessa mãe, ou na pessoa que exerce a função materna, uma imensa gama de suposições sobre cada som e cada choro pronunciado pelo bebê. Maneira através da qual ela vai tentando se apropriar do bebê, oferecendo-lhe um caminho a ser seguido de sentidos e significações, exercendo, portanto, a função de antecipação de existência subjetiva, impulsionada pelo seu próprio desejo, como afirma Kupfer (2000):

(...) uma mãe sustenta para seu bebê o lugar de Outro primordial. Impelida pelo desejo, antecipará em seu bebê uma existência subjetiva que ainda não está lá, mas que virá instalar-se justamente porque foi suposta (Kupfer, 2000, p. 49).

Enquanto o bebê não encontra o seu próprio sentido, só lhe resta corresponder aos sentidos que lhe atribuem, ao lugar que lhe conferem, caso contrário, não encontrará nenhuma referência e nenhum significado para si próprio.

É possível pensar que as apostas feitas pela professora seguiam por este mesmo caminho: frente ao desconhecido, afinal Caio estava tomando um caminho totalmente diferente, passaram a nomear o movimento apresentado por ele, dando sentido e significação: "Caio está mais fora do grupo, mas está se tornando um ser mais desejante". Apostas que podemos classificar como fundamentais e primordiais, de que 
há um sujeito habitando aquela criança. Entretanto, esses significantes, marcas simbólicas que vão representando o indivíduo para que ele possa existir enquanto sujeito, podem acabar deixando a criança no ar, uma vez que

"as palavras tem sua existência tão somente no registro Simbólico, são emissões sonoras cuja materialidade só faz sentido num sistema organizado como a língua" (Bernardino, 2006, p. 30).

Ou seja, sendo Caio uma criança autista, o simbólico não se constituiu, e o enodamento das instâncias Real, Imaginário e Simbólico, como propõe Lacan para que haja sujeito, não ocorreu.

Discorrer sobre o autismo e sua estruturação psíquica está muito além da proposta deste trabalho. No entanto, é importante considerar que a criança autista, diferente de uma neurótica, não possui o enodamento necessário para que emerja como um sujeito efeito do discurso. Há uma estruturação psíquica diferente. Dessa maneira, podemos pensar que a angústia nomeada por Renata em relação aCaio estar fora do caminho previsto, relaciona-se ao fato de perceber que, de certa forma, ele estava à deriva, já que as palavras só possuem sua existência no registro simbólico, exatamente a dificuldade que Caio possui. Dada a sua estruturação psíquica autística, ele não apresentava a enodamento dos três registros.

Todavia, num dado momento, a permissão para apropriar-se de seus desejos acabou lavando Caio para um lugar bem distante do grupo. Bem distante do que prega o imperativo da inclusão. Esse caminho “próprio' que Caio vai trilhando, o leva para longe e sai demasiadamente do caminho esperado para a sua inclusão.

"Então a gente começou a ficar muito angustiado também com essa situação de... tinha dias que ele não passava nem 10 minutos dentro da sala. Então isso começou a angustiar também".

"A gente entendia que era uma criança que estava se tornando mais desejante e isso a gente também valorizava. (...) Ah! Então, isso é uma coisa importante, porque nesse momento, ele acabou, nesse desejante, ficando muito solitário. Porque ele estava solitário no grupo. Tinha um processo que era dele de mais desejante, mas ele estava se... ficando muito sozinho, né, diante do grupo. Porque ele não estava compartilhando experiências...".

"É curioso, porque surgiu de novo a angústia. Acho que a angústia ela move nesses casos". 
Diante da cena na qual Caio - sendo colocado num lugar de sujeito desejante sem poder efetivamente ocupá-lo - estava se distanciando do caminho pretendido pela instituição e pelos seus professores. Ou seja, na impossibilidade de Caio assumir o lugar que lhe era designado no discurso, não correspondendo à produção que se esperava nesse discurso, algo novo pôde emergir. E na emergência de indícios particulares do caso em questão, parece ocorrer uma fratura da mestria institucional. Segundo a fala de Renata, a mobilização para tentar outra saída decorreu "de novo da angústia. Acho que ela move nesses casos" (sic). Frente à impotência refletida na inclusão não-correspondida decorrente da aposta de respeitar os desejos de Caio, os professores recorreram à reunião com outros educadores - dispositivo oferecido pela instituição - , na busca por outros meios possíveis de trazer Caio novamente para o grupo.

“(...) semanalmente a gente se reúne num encontro com todos os professores que tem no grupo alunos de inclusão e é um momento de troca, de conversa, de reflexão, de desabafo, algumas vezes. É importante. Às vezes, você escutando a experiência de um outro professor isso às vezes te alimenta na sua".

Podemos entender que nesse momento há uma passagem para um outro discurso, no qual a professora passa a enunciar a partir de $\$$ na posição de agente, demandando uma produção de saber e denunciando ao mesmo tempo, que o saber do mestre - discurso corrente a respeito do processo inclusivo de Caio - é não todo. $\mathrm{Na}$ instalação do discurso da histérica, Renata vai em busca de respostas e saberes no grupo de professores, e é no reconhecimento desta espécie de falha no processo da inclusão que algo novo pode emergir.

Parece que o que pôde ser discutido e pensado nesse momento de troca entre os educadores promoveu algumas mudanças:

\footnotetext{
"Mas acho que ficou um mês desejante e a gente falou: 'bom agora, dá para colocar um outro desafio sem perder de vista o desejante'. Então a gente estipulou que quando a Andrea vem, ele tem a possibilidade de sair para o quintal, de fazer as explorações dele com a Andrea no ambiente externo, e a gente continua, a gente consegue cuidar desse ser desejante".

"E agora, o Rafael e eu estamos com o grupo mais organizado, (...) e a gente fez esse pacto, junto com o Fabio, o monitor pedagógico: a gente vai tentar bancar, então de tentar fazer o Caio experimentar quando está o grupo inteiro".
}

Como visto, o que foi posto em ação nas discussões entre os educadores atuou 
na dinâmica que precipita a báscula de um discurso para o outro, e é neste sentido que se dá, como já apresentado, a emergência do discurso analítico, que nada mais é do que uma conseqüência do necessário giro dos elementos que compõem o ato da prática social da linguagem, um lugar de passagem de qualquer prática discursiva, como afirmou Jerusalinsky (1999).

Da mesma maneira que Ana em relação a Luís, Renata enquanto professora de Caio mudou as atitudes anteriormente assumidas em relação a ele. Da permissão para estar fora do grupo, passou a dar ênfase na sua permanência dentro, fazendo uma nova aposta de que naquele momento, essa era a melhor conduta a ser tomada.

Houve um giro dos discursos que produziu efeitos importantes, e não apenas um deslocamento de um discurso ao outro impondo, irrefletidamente, as regras que deveriam ser seguidas.

"Então a gente começou a bancar mais com que ele fique na roda, que ele fique nesses momentos coletivos e a gente percebeu que existe uma resistência inicial, até porque ele ficou um mês aí, todo felizão, então existe essa resistência, mas a gente conseguiu, por exemplo, garantir que ele fizesse algumas lições que o grupo estava fazendo. Nessa semana, ele fez a roda todos os dias, no colo do Rafael, mas fez todos os dias".

Renata também valorizou bastante o trabalho recebido por Caio, chamado de acompanhamento pedagógico, no qual um terceiro adulto vem compor com o trabalho dos dois professores com o foco na criança. Um dispositivo que foi oferecido pela escola após algumas reuniões e reflexões a respeito do que estava sendo feito com Caio. Esse dispositivo vai ao encontro do que Sekkel (2003) e Fráguas (2003) apontam em suas pesquisas sobre a existência de um educador que atue junto à criança em situação de inclusão dentro do ambiente escolar com o objetivo de trazê-la para o grupo, pois puderam comprovar que essa presença, além da dos professores, ajudou a promover mudanças no funcionamento psíquico e social dessas crianças.

Além dos dispositivos já assinalados — acompanhamento pedagógico e as reuniões de troca coletivas entre os professores - Renata revela um outro ponto que considera positivo sobre a possibilidade existente na instituição de se promover reuniões inter e multidisciplinares entre os profissionais envolvidos com as crianças e os profissionais da escola. Em consonância com Sekkel (2003), Renata considera que essa proposta favorece a troca de conhecimentos e experiências importantes para a condução do trabalho e para o alcance do sucesso do processo inclusivo: 
"Outra coisa que eu acho que contribui muito com o nosso trabalho é a possibilidade que essa escola dá de receber os profissionais outros que atendem essas crianças, para a gente compor uma rede mesmo, efetiva. Então a gente foi primeiro na clínica onde ele é atendido, a gente conversou com a psicóloga e com a fono (...) e agora, no segundo semestre, elas vieram aqui na escola. Então tinha (...): os dois professores do Caio, a acompanhante, a professora de apoio de inclusão, a coordenadora, a fono e a psicóloga. E foi muito interessante compartilhar histórias e aguçar o olhar. Perceber que alguns comportamentos que ele tem tido aqui, ele tem tido lá, então, poder entender ele mais no macro, não só como um recorte escolar, poder se debruçar e pensar no Caio enquanto ser na totalidade".

A partir desse relato, é possível pensar que as circunstâncias instituicionais os suportes oferecidos pela instituição - até aqui apresentadas, foi um dos elementos que puderam favorecer algumas das operações necessárias para o encaminhamento da modificação da impossibilidade da inclusão, ou seja, para o sucesso.

\section{2.d João}

Luciana, 30 anos, pedagoga, é professora de João que entrou na escola no mês de agosto de 2010, no G3 com crianças de 3 anos. Antes de efetivar a matrícula, a mãe de João procurou a escola para contar sobre o seu histórico. Contou à coordenadora que ele sofrera anoxia durante o parto o que fez com que ele tivesse uma série de seqüelas que afetaram o seu desenvolvimento. A entrada na escola era o seu primeiro contato social com outras crianças, uma vez que, até aquele momento, ele praticamente não saía de casa (apenas para ir à fonoaudióloga, à terapeuta ocupacional (T.O.) e à equoterapia), além de ter recém-saído da alimentação por sonda gástrica.

Sua adaptação à escola foi um pouco sofrida. João chorava bastante no momento de se despedir da mãe e demorava para se acalmar. Os primeiros dias foram dedicados a recebê-lo, conhecê-lo e permitir que se sentisse confortável nesse novo ambiente. Entretanto, João ficou muito doente e faltou muito na escola e esse fato contribuiu para que sua adaptação e seu processo de socialização no grupo ficassem prejudicados.

Independentemente disso, as professoras investiram bastante para que nos dias em que estava presente pudesse aproveitar o que era oferecido em grupo, atividades que eram pensadas com o objetivo de integrá-lo ao grupo. Contudo, João não demonstrava interesse em nada do que lhe era oferecido. Sua atenção voltava-se 
apenas para o ventilador e perguntava para quem estivesse por perto: "quem ligou o ventilador?" ou “quem desligou o ventilador?".

Ao final do ano, diversas avaliações haviam sido feitas entre a equipe pedagógica da escola e a família de João. Decidiu-se que ele refaria a mesma série pensando nos desafios e conquistas que ele ainda teria por vivenciar no próprio G3 e na importância dele começar um grupo desde o início do ano.

Em 2011, ele continuou com as mesmas professoras, mas com um novo grupo de crianças.

A partir da entrevista com a professora Luciana, é possível acompanhar o avanço que João teve durante um ano e meio de escola e vivência social e quais foram os pontos marcantes que permitiram a mudança de posição da criança na escola.

"Quando ele chegou na escola, teve o momento de adaptação dele, de observação, um foco muito no individual, porque ele precisava de uns caminhos fortalecidos com a gente."

"Quando ele chegou na escola, tinha acabado de sair da sonda, então tinha uma questão com a alimentação que era superdifícil, tinha uma questão motora que também era muito difícil. Mas ele tem uma família que (...) tinha um cuidado com as questões individuais dele, mas ele não tinha essa inserção no social."

"aliás, ele é uma criança que estabelece vínculos com os adultos facilmente, mas tem uma dificuldade grande em entrar no universo das crianças."

"sempre colocou ele em muitos tratamentos, que teve muito cuidado com ele em relação a esses tratamentos para buscar melhorias. Então ele fazia algumas coisas fora da escola, antes de vir para a escola, e depois continuou fazendo algumas coisas também",

"Era muito difícil para ele andar nesse chão que é um pouco disforme, ele tem uma questão motora, ele tem as pernas bem fininhas, parece que são frágeis. Então, no começo teve um movimento de olhar para ele individualmente, e de já tentar fazer a entrada no grupo, mas que era uma entrada... de primeira vez ainda.”.

Enquanto descreve o momento da entrada de João na escola, é possível identificar na fala da educadora Luciana, o lugar que ele ocupava no discurso institucional. Lugar de uma criança frágil e que precisava de um olhar atento para suas questões individuais: alimentação, coordenação motora, estabelecimento de vínculo com as professoras, bem como a maneira através da qual ele se relacionava com as pessoas (somente com os adultos).

"O desafio que tínhamos com ele era fazer olhar para as outras crianças (...) O que nós precisamos fazer com ele foi, (...) fazer ele se voltar mais para os assuntos que 
tinham a ver com o grupo e com as relações".

"no começo ele ficava de costas para roda, olhando para o ventilador ou para a janela, sem se dar conta de que estava de costas para a roda (de conversa do grupo)."

Ao longo do discurso da educadora, vemos que havia um direcionamento para o trabalho inicial com João, que partia de suas questões particulares em direção ao objetivo de inseri-lo no grupo, fazendo com que se interessasse pelas questões coletivas e grupais. Contudo, por mais que a direção do trabalho - a ocorrência da inclusão - estivesse em pauta e sendo colocada em prática, João não correspondia ao que era esperado. Mesmo dentro da sala de aula, seus interesses continuavam distantes do que era compartilhado entre as crianças. Do mesmo modo, o seu comportamento, virado de costas para o grupo, revelava uma espécie de obstáculo a tentativa de ser colocado no lugar de objeto a ser adaptado ou inserido, ao imperativo do 'seja incluído'.

Vemos aqui a estrutura discursiva do momento da entrada de João na escola:

$\frac{\mathrm{S} 2}{\mathrm{~S} 1} \underset{\$}{\rightarrow} a \quad \underline{\text { Sabemos como fazer para incluir João }} \rightarrow \underset{\text { João não realiza a inclusão proposta }}{\underline{\text { João incluído }}}$

Munida dos saberes sobre como promover a inclusão de João, agenciando o discurso do universitário, a instituição pregou os conhecimentos e tentou usá-los na prática cotidiana com a criança. Contudo, parece que João não cumpria o ideal decorrente do lugar de objeto ao qual o agente do discurso lhe designava evidenciando a improcedência do imperativo da inclusão se efetivar.

"A gente fez esforço aqui na escola de trazer muitas atividades em que ele pudesse participar."

Por mais que houvesse esforços por parte da educadora e da escola em alcançar o sucesso do processo inclusivo de João, eles se mostravam insuficientes, uma vez que João continuava distante do que lhe era imposto.

Diante dessa improcedência, tivemos a emergência de algo particular deste caso, revelado em João não cumprir o ideal do lugar de destinatário do discurso. Frente a isso, tem-se a modificação do olhar de Luciana dirigido a João e ao seu processo inclusivo, que parece ter decorrido de uma espécie de confrontação com o 
seu próprio dizer. Uma vez que a inclusão de João não ocorria da maneira que deveria, ela precisou mudar as atitudes em relação a ele.

Nessa mudança, também é possível acompanhar o giro que ocorre no discurso, no qual há a precipitação da báscula com a emergência do discurso da histérica:

$\frac{\$}{a} \rightarrow \frac{\mathrm{S} 1}{\mathrm{~S} 2} \quad \frac{\text { Não sabemos o que fazer com João }}{\text { Não adianta impor a inclusão }} \rightarrow \frac{\text { Alguém deve saber }}{\text { Buscam-se respostas }}$

Vemos a instalação do discurso da histérica no momento no qual João parece denunciar a improcedência da imposição da inclusão. Enunciando a partir do lugar de sujeito barrado (\$), Luciana desestabiliza e provoca questionamentos para o sujeito.

"Mas a gente ficou com um problema para resolver. Isso porque, quando ele entrou na escola, a família estava bem junto e próxima, mas depois a gente notou que era uma família que estava um pouco cansada de acompanhar tantas questões que ele trazia."

"Então, teve um momento de muita ausência dessa família na escola... até em função desse cansaço... e não deve ser fácil. Ausência da família e ausência dele na escola. Ele faltou muito no primeiro ano de escola."

"E chegou um momento em que tivemos que chamar essa família e falar: 'Olha, vocês precisam fazer junto com ele essa entrada no coletivo. Ele precisa vir de casa sabendo o que vai acontecer na escola. Então, vocês precisam saber o que vai acontecer na escola para ele também saber.' A gente quis colocar ele mais dentro dos assuntos coletivos."

No ato de chamar a família e implicá-la no processo inclusivo de João, vemos a educadora sair da posição de queixa para assumir o lugar de questionamento em busca da solução do enigma. Na tentativa de ir atrás de algo que pudesse contribuir para a inclusão de João, a educadora resolve chamar a família, apostando que essa estratégia seria mais um elemento positivo na conversão de esforços no trabalho com João.

A compreensão do que estava em jogo nesta situação permitiu à educadora encontrar não somente diferentes apostas e maneiras de ajudar a inclusão de João, como também a não devolver à criança a mesma palavra repetida pela família: de cansaço, esgotamento e desistência.

"Nós tivemos algumas interferências com essa família para conseguir isso com ele, e eu tive um resultado muito grande, principalmente no final de tudo isso, que faz uns dois meses que a gente vê um resultado bem nítido." 
"Mas também, depois que a gente chamou essa família para conversar e pontuamos que ele precisava dessa ponte, e que sem isso, ele sozinho não iria construir essa ponte, essa família passou a ter uma participação mais efetiva. Então, por exemplo: era dia de culinária e ele passou a trazer ingredientes, coisa que ele não fazia antes, no dia de brinquedo passou a trazer brinquedo, coisa que também não fazia antes."

"essa ponte que fez com que o João entrasse nesse grupo. E entrasse nesse grupo, não só ele entrar no grupo, mas o grupo fez um movimento de buscar o João."

"Agora ele está num movimento em que ele chega e fica de frente para roda e escolhe um lugar em que se sinta mais confortável para sentar. Tem duas crianças que são referências maiores para ele, e ele está de frente para a roda agora. E não foi algo nosso, é algo que parte dele querer estar na roda. Por mais que de vez em quando ele escape para os seus assuntos, olhar para o ventilador ou para a janela, ele está de corpo presente com a gente."

Parece que ao não permanecer presa no emaranhado da queixa paralisante, Luciana passa a se questionar sobre as possibilidades existentes de se fazer algum trabalho efetivo com João. Tenta trazer a família para perto como colaboradora importante para que o trabalho pudesse acontecer. Felizmente, ela pôde ressignificar o seu fazer educativo com João e encontrar saídas possíveis para ele, sendo reconhecido, agora, em sua singularidade e não mais como objeto a ser incluído.

Luciana aponta também para outros fatores que contribuíram para o sucesso da inclusão de João, entre eles o fato de ter refeito a mesma série. Decisão que foi tomada depois de muitas reflexões pelos educadores da instituição em conjunto com a família.

"O fato de ele ter ficado dois anos na mesma série foi uma decisão difícil que eu, enquanto professora, pensava "poxa, vai ter que repetir? Mas ele é tão capaz, ele pode seguir para o próximo ano". Mas na verdade, a escola olhou por um outro viés que, hoje eu tenho certeza de que fizemos a escolha certa, que realmente ele precisava viver aquilo desde o começo, ele precisava viver um grupo desde o começo, construir junto esse processo e não pegar pela metade.

Outro fator importante e que parece ter contribuído para a inclusão de João, foi a possibilidade oferecida pela própria instituição de um acompanhamento pedagógico.

"Durante esse ano, a gente pensou bastante no acompanhamento para ele. Isso foi importante porque ao olhar para uma criança dentro de um grupo, no caso o João, talvez seria uma criança que pensaríamos 'nossa, acho que dá para levar' porque ele não é uma criança difícil no sentido de... ele não faz o grupo caminhar de jeitos diferentes, ele não interfere muito nesse caminho do grupo."

"Ele não é uma criança agressiva, que às vezes a gente considera essa agressividade num lugar de precisar de acompanhamento. As questões dele eram outras e foi bem 
importante ponderar isso e pensar no trabalho de acompanhamento para ele, de poder olhar para a necessidade de um acompanhamento, mesmo que não fosse uma questão considerada difícil. Mas era uma dificuldade para ele".

"A maior questão dele era a entrada no grupo, no social, compartilhar os assuntos do coletivo. Então a gente fez a escolha de ele ter uma acompanhamento que fica com ele, poucas horas. O que é legal, pois ele não tem que ficar o tempo inteiro tendo que conviver com essa necessidade, mas ele fica com ela quatro horas semanais e ela faz algo mais intenso em relação a essa vivência no social."

E, por fim, apresenta o conjunto de fatores que contribuíram para que a inclusão de João atingisse aquilo que era considerado como sucesso, por parte da escola.

"E a gente viu muitas transformações nele, foram várias coisas que se uniram: tem algo dele que se mostrou uma criança forte para ter essas conquistas, tem o acompanhamento, o nosso olhar de conseguir fazer intervenções diferentes, e de olhar para o momento em que ele podia enfrentar os desafios, teve a estrutura da escola que ajudou bastante e, além disso, a gente viu mudança quando a família teve essa entrada maior, eles colaboraram muito para a entrada do João em nosso grupo."

"Bom, e na verdade a gente viveu algumas fases desse trabalho com ele, as mudanças tiveram muito a ver com o respaldo que a gente teve na escola. Por quê? Porque era uma dinâmica que precisava de muita mudança e de intervenções diferentes a cada momento. $\mathbf{E}$ essas mudanças aconteceram muito com as reflexões que a gente tinha junto essa equipe aqui na escola. A escola ofereceu grupos de conversa e mesmo na coordenação, individual e com as pessoas que cuidam disso aqui na escola. Então foi muito bom para a gente sair desse dia-a-dia que às vezes leva a gente a intervenções com uma constância parecida. Então era muito bom para mudar o rumo das coisas com ele."

Aqui também parece evidente que os dispositivos instituicionais de suporte para o trabalho educativo e, nesse caso, o trabalho com a inclusão contribuíram para as operações necessárias para o encaminhamento do sucesso da inclusão escolar.

"E agora, depois de um ano e meio ele vem mostrando para gente que a fragilidade é aparente, e que por trás tem muita força. Ele pode construir uma rotina comum com o grupo em conjunto. Agora ele está pronto para viver novos desafios."

No contexto dos relatos apresentados até o momento, podemos identificar educadoras e crianças enlaçadas em uma estrutura discursiva que marca lugares e posições importantes de serem localizados na rede de linguagem que se estabelece na instituição escolar. Nota-se que os indicadores sinalizados nos relatos foram elementos significativamente importantes para que o trabalho inclusivo com estas quatro crianças se tornasse possível, e, consequentemente, atingisse o sucesso de acordo com as avaliações pessoais dos sujeitos entrevistados. Temos também 
informações que revelam que as circunstâncias institucionais - suportes fornecidos pela escola - possibilitaram o caminho para o sucesso, oferecendo possibilidades para ele se efetivar e contribuindo para a promoção de uma prática educativa mobilizadora levando ao reconhecimento das crianças em suas singularidades.

Não podemos deixar de ressaltar que a intenção de utilizar como método a teoria lacaniana dos quatro discursos é maior do que simplesmente analisar os discursos envolvidos na pesquisa. Os fragmentos, tal como estão sendo apresentados, trazem consigo a tentativa de ajudar a pensar sobre como manejar quando um discurso está sendo enunciado e a compreender como se dão as passagens de um discurso ao outro, consideração fundamental, uma vez que os discursos são maneiras peculiares de um sujeito ligar-se ao outro e que, portanto, implicam diversos modos de enlaçamento e de posicionamento que não são sempre estáveis.

Como apresentado no início do capítulo, todas as educadoras da instituição pesquisada - que se encontravam dentro da delimitação do campo estabelecido participaram da pesquisa, fato que configurou uma amostra fechada por exaustão. Por esse motivo, a pesquisa se estendeu a uma instituição distinta, até que a saturação se desse por completo.

Em seguida, acompanharemos a contextualização da segunda instituição pesquisada e as respectivas entrevistas realizadas.

\subsection{Sobre a creche pesquisada}

A segunda instituição pesquisada faz parte de uma divisão de creches que tem como objetivo atender gratuitamente as crianças filhas de funcionários, docentes e alunos de uma universidade da cidade de São Paulo, e visa contemplar as necessidades de desenvolvimento intelectual e o acesso ao saber, bem como o direito à socialização, às vivências infantis e aos cuidados assistenciais específicos e necessários.

A creche mantém estreitas relações com a comunidade na qual está inserida e desde a sua origem pertence à rede de divisão de creches. A história das creches nesta universidade data de 1965, quando a comunidade começou a buscar um espaço para seus filhos. Dessa data para cá, o serviço de creches foi ampliado e hoje atende 
aproximadamente a 640 crianças, distribuídas em cinco creches, sendo três na cidade de São Paulo e duas no interior do Estado.

\section{A creche pesquisada ${ }^{22}$}

Em 1986, a creche iniciou o atendimento exclusivo a 25 crianças, filhos desses? trabalhadores. No ano de 1990, recebeu um novo prédio composto por três segmentos: prédio administrativo com mezanino, módulo I e módulo II, para atender 110 crianças, dependentes de funcionários $(85 \%)$, docentes $(10 \%)$ e estudantes $(05 \%)$ de todas as unidades da universidade.

A creche vem construindo seu Projeto Político Pedagógico na relação com as crianças, professores, funcionários e pais. Conforme documento síntese da proposta pedagógica, concebe-se como uma instituição educacional na qual a criança tem direito à brincadeira, à atenção individual, ao afeto, ao ambiente seguro e desafiante, à higiene, à saúde e à alimentação. A instituição procura propiciar às crianças um desenvolvimento integral nos aspectos físico, cognitivo, moral, emocional e social para que possam construir sua identidade pessoal e cultura. Considera importante que a criança seja considerada como sujeito da infância, ou seja, em um momento decisivo da sua constituição subjetiva.

$\mathrm{Na}$ creche, parte-se da concepção de que a criança é um ser curioso, pensante, que produz conhecimento e cultura. À medida em que pode participar de muitas brincadeiras, recriá-las, reelaborá-las e ressignificá-las, apropria-se dos espaços da creche, dos objetos e dos brinquedos de variadas formas. Sendo assim, através da mediação do outro que ensina, aprende e faz junto, a criança constrói seu mundo de cultura, um sistema de comunicação e uma rede de significados e, portanto, expressões culturais específicas.

De acordo com o documento de regimento interno da divisão de creches, todas as creches vinculadas ao programa têm por finalidade o atendimento às crianças de 4 meses a 5 anos e 11 meses, filhos de funcionários, docentes e alunos de todas as unidades da universidade na qual está inserida.

A creche atende aproximadamente a 110 crianças, sendo as vagas divididas proporcionalmente entre: filhos de funcionários $(40 \%$, sendo $7 \%$ para filhos de funcionários de creche), filhos de docentes (20\%) e filhos de alunos (40\%). As vagas

\footnotetext{
${ }^{22}$ Todas as informações foram gentilmente cedidas pela creche pesquisada e baseiam-se em seu Projeto Pedagógico.
} 
oferecidas são distribuídas por faixa etária e por categoria (funcionário, docente e aluno) e o processo seletivo é realizado uma vez por ano no mês de dezembro. Participam do processo seletivo todas as crianças inscritas para a seleção que tenham idades compatíveis com as vagas oferecidas.

O critério de seleção para admissão de crianças é socioeconômico e, para tanto, alguns fatores são importantes, dentre eles há: situação familiar de risco à criança, situação de orfandade ou se há presença de irmão na creche.

Ao fim do processo seletivo, é elaborada uma lista classificatória e as crianças selecionadas são chamadas para matrícula.

O horário de funcionamento da creche é das 7 às $18 \mathrm{~h} 30$ e durante este período existem diferentes horários estabelecidos para a entrada e saída das crianças.

A creche está organizada a partir de dois grandes grupos, o Módulo I e o Módulo II, subdivididos em 3 grupos de crianças, organizados por faixa etária:

\begin{tabular}{|c|c|}
\hline $\begin{array}{c}\text { Módulo I } \\
\text { (de } 4 \text { meses a } 3 \text { anos) }\end{array}$ & Crianças por grupo \\
\hline Berçário & 14 crianças \\
\hline G2 & 15 crianças \\
\hline G3 & 15 criancas \\
\hline $\begin{array}{c}\text { Módulo I } \\
\text { (de } 3 \text { a } 6 \text { anos) }\end{array}$ & \\
\hline G4 & 20 crianças \\
\hline G5 & 20 criancas \\
\hline G6 & 20 crianças \\
\hline Total geral & 104 crianças \\
\hline
\end{tabular}

No momento da pesquisa, a creche contava com 109 criancas matriculadas.

A creche conta com 44 funcionários e 2 estagiários para o desenvolvimento de um trabalho de qualidade. Os professores e as técnicas de enfermagem trabalham 6 horas diárias, nos períodos da manhã e tarde, viabilizando o atendimento às crianças em período integral. Os outros funcionários têm um contrato de trabalho de 8 horas diárias. 
O quadro de pessoal (número de funcionários e função) é composto da seguinte maneira:

\begin{tabular}{|c|c|}
\hline Quantidade & Função \\
\hline 02 & Auxiliar de cozinha \\
\hline 04 & Auxiliar de serviços gerais \\
\hline 02 & Técnicos(as) de enfermagem \\
\hline 01 & Auxiliar administrativo \\
\hline 01 & Cozinheiro(a) \\
\hline 01 & Diretor(a) \\
\hline 26 & Professores(as) ${ }^{23}$ \\
\hline 03 & 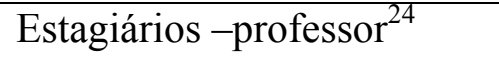 \\
\hline 02 & Estagiários* \\
\hline 01 & Lactarista \\
\hline 01 & Pedagoga \\
\hline 01 & Psicóloga \\
\hline 01 & Pedreiro \\
\hline 01 & Técnico-administrativo \\
\hline 01 & Técnico de nutrição \\
\hline 01 & Zelador \\
\hline 49 & Total \\
\hline
\end{tabular}

* Nos últimos anos, houve a necessidade de contratação de estagiários de outros cursos para trabalhar com educadores e crianças no que diz respeito às inclusões.

Desde a inauguração da primeira creche da divisão de creches, a equipe central exigiu para contratação de professores a formação mínima com magistério, ou mesmo Ensino Médio, e muitos cursavam o Ensino Superior.

\section{Formação}

A formação da equipe pedagógica da creche se dá de três maneiras diferentes: formação continuada mensal, reuniões de grupo e reuniões de módulo.

\section{Formação continuada mensal}

\footnotetext{
${ }^{23} \mathrm{Na}$ creche existem duas professoras que trabalham 8 horas e não têm grupo de crianças. Uma delas é responsável também pela articulação dos dois períodos: manhã e tarde. A outra professora é responsável em tempo integral pela Oficina de Informação.

${ }^{24}$ Atualmente, a creche conta com três estagiários estudantes de pedagogia. Esses estagiários têm a mesma função dos professores, porém o vínculo empregatício é diferente.
} 
Agendadas no início de cada ano, as reuniões acontecem às segundas no período da tarde ou às sextas-feiras no período da manhã. Nesses dias, as creches não atendem às crianças. Todos os funcionários comparecem e são programadas oficinas, palestras, reuniões em grupos diversificados, de acordo com os temas em questão. É um momento fundamental para a construção do coletivo, pois todos os funcionários estão reunidos no mesmo horário, discutindo diversos assuntos, que vão desde o trabalho junto às crianças até normas de convivência entre os adultos. Também, nesses dias, é reservada 1 hora para os funcionários discutirem questões específicas da vida funcional na universidade.

A cada ano, elege-se um eixo de formação específico que será trabalhado ao longo dos meses, promovendo debates sobre teoria e prática, incluindo a participação de especialistas que possam contribuir para enriquecer o trabalho na creche.

\section{Reunião de grupo}

As reuniões de grupo são realizadas semanalmente, no horário das $12 \mathrm{~h} 15$ às 13h, com a participação dos professores da manhã e da tarde de cada grupo de crianças e de uma das técnicas (pedagoga ou psicóloga).

No início do ano são realizadas várias reuniões com os professores com o objetivo de organizar a seqüência didática semanal de cada grupo. Além disso, neste início de trabalho os professores iniciam os planejamentos dos projetos após um período de observação e levantamento dos interesses das crianças.

Nas reuniões pedagógicas discute-se encaminhamentos para os planejamentos, organização de espaços e agrupamentos. Assim como os relatórios de grupo, que descrevem momentos significativos dos projetos de trabalhos e são destinados às famílias. As reuniões de pais são elaboradas pelos professores, inclusive muitas delas, além de ter vídeo e fotografias registrando o processo dos projetos, oferecem oficinas para os pais participarem.

As reuniões com a psicóloga abordam questões sobre as relações entre as crianças, entre as crianças e os professores e entre as crianças e suas famílias. Nesses encontros também são abordadas questões mais particulares de cada criança, alguns grupos e para os diversos movimentos que o grupo apresenta ao longo do ano. Os relatórios individuais de cada criança também são discutidos nesse espaço.

\section{Reunião de módulo}

Esta reunião garante a participação dos professores do período da manhã e da tarde de cada módulo (Módulo I - crianças de 0 a 3 anos e Módulo II - crianças de 3 
a 6 anos), no horário das $12 \mathrm{~h} 30$ às $13 \mathrm{~h} 15$.

O formato, a metodologia e a coordenação das reuniões de módulo variam de acordo com a temática definida pelo grupo junto aos técnicos.

\section{Das entrevistas ${ }^{25}$}

Diferente das entrevistas colhidas na primeira instituição, a análise das entrevistas realizadas na creche não apresentam um histórico detalhado do percurso da criança na instituição. As informações sobre as crianças citadas foram colhidas exclusivamente dos discursos das educadoras. Contudo, o modo de apresentação da entrevista foi o mesmo, bem como as intervenções feitas a fim de que mais informações sobre o processo de inclusão pudessem ser evidenciadas.

\section{3a Catarina}

Maria é pedagoga, tem quarenta e quatro anos e trabalha na creche há doze anos, foi professora de Catarina, que entrou no berçário da creche no ano de 2010. No ano seguinte, por volta dos dois anos de idade, ela acompanhou o grupo na passagem para o G2, ano no qual foi aluna de Maria. No relato da educadora podemos acompanhar sua experiência enquanto professora de Catarina, diagnosticada com síndrome de Edwards ${ }^{26}$. Durante a fala de Maria é possível identificar as dúvidas que permearam o início de seu trabalho com Catarina e o caminho que foi percorrendo para que a inclusão da criança ocorresse.

"A Catarina chegou no berçário e eu fui professora dela no G2 e eu não falo do berçário porque eu não tive acesso então eu não sei como foi o trabalho lá (...) Eu fiquei muito apreensiva no início".

“(... ) tivemos várias reuniões e eu falava pra Psicóloga que eu estava apreensiva no começo, porque como receber uma criança que depois de vários cuidados... ela recebia tudo por uma sonda gástrica, e a gente precisava oferecer água, alimentação...".

“Porque, a princípio a gente pensava assim: 'Ah, será que dá? Será que não dá?".

"Ela não ficava só no nosso colo, a gente colocava ela no chão, mas ela não andava. A gente colocava ela no chão, ela ficava deitada ou às vezes sentada, mas quando gente ia de um espaço para outro, a gente levava ela no colo (...) uma vez por semana a gente tem oficina quando eles levam livros para casa, aí a gente tinha que subir com

\footnotetext{
${ }^{25}$ Todos os nomes atribuídos às crianças e aos adultos nos recortes apresentados são fictícios, em conformidade com o código de ética no que diz respeito à preservação da identidade dos sujeitos.

26 Síndrome de Edwards é uma trissomia do cromossomo 18, que traz algumas características entre as quais destacam-se: baixo peso ao nascer, hipotonia seguida de hipertonia, malformações que afetam o coração, cérebro, rins e aparelho digestivo, dentre outras.
} 
ela no colo, mas nos momentos de atividade a gente meio que ajudava também”.

"Nós éramos em duas (professoras), o grupo tinha 15 crianças e nesses momentos de alimentação e de troca, não que eu me ausentava, mas eu ficava mais próxima da Catarina e a outra educadora ficava com o grupo".

A partir do relato de Maria, podemos acompanhar o percurso e o processo de recebimento de Catarina, no início do ano letivo, com as diversas demandas em relação à alimentação e à locomoção. Vemos Maria assumir a angústia e a inquietação que a acometeram no momento em que soube que teria Catarina entre as crianças de seu grupo. Em meio à apreensão, dúvidas surgiram, dentre as quais destacamos: se ela teria condicões de cuidar dessa criança e como faria para desenvolver um trabalho com uma menina que lhe parecia tão frágil e comprometida quanto imaginava. E aqui surge uma construção imaginária a respeito do que ela supunha ser a fragilidade de Catarina e de seus cuidados necessários, antes mesmo de conhecê-la.

"Porque era uma coisa diferente, tinha a seringa, a gente tinha que encher e colocar. A gente até fez várias atividades para que as crianças pudessem entender porque é que eu estava ali naquele momento, porque eu era professora de todos e, por que de repente, em algum momento e me afastava e tinha que fazer essa administração da alimentação? Porque era tudo via sonda, não era nada via oral. E a gente fez um trabalho e as crianças também puderam entender porque ela recebia alimentação por ali...".

'Porque eu pensava 'Meu Deus, como eu vou fazer?' não que não seja possível, é possível, mas a gente fica um pouco apreensiva. Mas eu acho que a mãe, a adaptação com a mãe, com as enfermeiras, foi tranquilo. Eu acho bacana essa possibilidade e aí eu fui ficando mais tranquila, fui fazendo as coisas mais do jeito que tinha que ser feito.

Vemos também Maria presa na queixa sobre como proceder com os cuidados com Catarina chegando a cogitar que seria um trabalho impossível. Maria inicia o ano como professora de Catarina e agencia o discurso universitário:

$\frac{\mathrm{S} 2}{\mathrm{~S} 1} \rightarrow \frac{a}{\$} \frac{\text { Saber sobre a deficiência de Catarina }}{\text { Saber que tampona a falta }} \rightarrow \frac{\text { Criança deve cumprir com o imperativo da inclusão }}{\text { Alienação da questão singular }}$

Na certeza das dificuldades de Catarina, Maria só podia colocá-la no lugar de objeto do conhecimento científico, que demandava um conhecimento altamente preparado para tomá-la em seus cuidados, até que algo parece mudar seu preconceito sobre a possibilidade de cuidar de Catarina. 
"Teve uma época em que nós, educadoras, começamos a fazer (a alimentação via sonda), então a gente aprendeu também a fazer e a lidar com isso. Que também não é nenhum bicho de sete cabeças, no começo eu pensei que fosse uma coisa muito... mas depois eu vi que não, que dava para fazer sim, e que dava para ela ficar sim com as crianças nesse espaço."

"E a mãe foi também trazendo muito essa possibilidade para a gente, porque a mãe teve um período de adaptação com a gente então ela foi mostrando como ela fazia, que não tinha problema, que podia pegar, que podia trocar a fralda, que não tinha problema, que se caísse era só chamar a enfermeira que a enfermeira vinha e colocava de novo. Ela foi trazendo segurança também".

Aqui aparece um ponto importante, pois a presença da mãe de Catarina durante o processo de adaptação foi altamente relevante e determinante para que Maria pudesse se autorizar a se lançar nos cuidados diários com a criança. Os cuidados maternos observados pela educadora ajudaram na desconstrução das formações imaginárias que se tinha sobre Catarina, e permitiram o início do reconhecimento da posição do sujeito no discurso institucional e, portanto, de Catarina em sua singularidade. A partir disso, Maria pôde dar-se conta de sua implicação sujetiva enquanto professora dessa criança, e passou a ter práticas em relação a Catarina, que favorecessem sua inclusão no grupo e no trabalho.

O fato de não encontrar na mãe da criança as dificuldades em relação aos cuidados que a princípio imaginava e nem a necessidade de um conhecimento técnico-científico para lidar com ela - e, portanto, de constatar que cuidar de Catarina era bem mais simples do que imaginava - , obriga Maria a deparar-se com a quebra no laço de sustentação desse discurso. Discurso que denuncia sua fala como um aparelho de linguagem a serviço de algo que ela própria desconhece. Ao não encontrar na relação mãe-criança o "espelho" que reflete e ratifica a sua certeza imaginária da possível dificuldade de cuidar da criança, Maria faz um giro em sua produção discursiva e se lança em um novo discurso na tentativa de produzir algo novo.

Após o giro discursivo, temos a emergência do discuso do mestre:

$\frac{\mathrm{S} 1}{\$} \rightarrow \frac{\mathrm{S} 2}{a} \frac{\text { O trabalho com Catarina deve ocorrer }}{\text { Catarina está incluída? }} \rightarrow \frac{\text { Professores conseguem desenvolver um trabalho com ela }}{\text { Catarina participa das propostas e das atividades }}$

Ao demandar conhecimentos que desconhecia e ao se deparar com nenhuma resposta sobre como proceder com Catarina, vemos a educadora se lançar num 
desafio, tendo de elaborar um saber próprio a respeito de sua realidade educacional. Tal constatação promove um novo giro discursivo, no qual Maria volta a agenciar a partir do discurso do mestre, não mais colocando o saber no conhecimento científico sobre a síndrome de Catarina, mas no aprendizado diário com a própria criança, sendo considerada agora em sua singularidade.

"A gente, é... adaptou várias coisas, por exemplo, aonde ela ia ficar na roda sentada a gente adaptou com um móvel de espuma e uma almofada de espuma, e ela participava das rodas, dos projetos... A alimentação também era junto das crianças".

"Na hora da roda, de contar história, ela estava sempre presente. O nosso trabalho do ano passado, a gente trabalhou muito as sensações e nesse trabalho deu também para contemplar as necessidades da Catarina naquele momento. Então isso colaborou, não só para o grupo (...) e calhou que também ajudou a Catarina.

"Ela respondia muito e a gente ficava muito feliz, pensávamos 'poxa, a gente está fazendo alguma coisa que também está, tanto pro grupo quanto pra ela, sendo útil"”.

"A gente trabalhou com placas, tinha vários pedacinhos de papel, livro, grosso, fino, áspero, e a gente podia colocar a mãozinha dela, ela ia sentindo... tecido, a gente pendurava vários tecidos nas árvores, as crianças passavam por baixo, a gente passava junto com ela, porque ela também não andava, era só no colo. Então a gente meio que ia junto com ela também".

"E para ela isso foi muito bom... ela sorria, ela demonstrava o que estava sentindo pelo sorriso. Porque ela não falava, ela só emitia sons, mas nada de falar. Eu acho que foi uma experiência muito rica, não só para a gente, não só para mim como educadora, mas para todo mundo aqui da creche como para as crianças também."

"E esse projeto também teve muita coisa de... a gente entrou com rede porque a gente falava muito do vento, então os tecidos que a gente pendurava nas árvores eram para sentir essa coisa do frescor, a sensação do balançar. E isso calhou também, né, pra adaptação dela".

“A gente cantava muito, então porque cantando você dá um contorno, né, para as crianças. E ela ouvia muito, ela gostava muito das músicas, aí a gente fez uma pasta para as mães terem essas letras das músicas que a gente cantava aqui na creche para cantarem em casa. Então ela (a mãe) falava que cantava e percebia uma coisa, ouvindo ela (Catarina) sorria, dava um sorriso, então ela estava respondendo a alguma coisa".

Vemos Maria operar no discurso do mestre, pensando e escolhendo as propostas e atividades para Catarina, bem como os cuidados que lhe deveriam ser dirigidos durante a rotina escolar, uma operação que fica marcada pelo esvaziamento do mestre como inflação imaginária em prol da sua reconvocação enquanto lei simbólica. A lei simbólica trazida para o ato educativo promovido por Maria apostou em Catarina, a 
partir dos sinais que ela própria foi fornecendo (como o sorriso) considerando-a em sua singularidade.

Em relação aos suportes oferecidos pela creche que puderam contribuir com o trabalho de inclusão de Catarina, Maria aponta para alguns dispositivos os quais considerou importantes para o desenvolvimento de seu trabalho. Um deles foi a presença de uma estagiária de terapia ocupacional e de um enfermeiro que trabalharam em parceria com a educadora para ajudá-la com os cuidados alimentares e no trabalho com a criança. O outro dispositivo, também destacado por ela, são os espaços de reunião, troca e planejamento, momentos nos quais educadoras e estagiária podiam refletir sobre o trabalho que desenvolviam com Catarina e pensar juntas no planejamento a ser realizado.

"No início, até tinha uma pessoa (estagiária), só que no ano passado a gente teve muitas ocorrências (...). Mas a gente teve sim uma estagiária que ajudava, que era para ficar mais próxima da Catarina. (...) depois veio o enfermeiro, mas também era só nessa parte da alimentação que ele entrava"

"A gente tem dentro da semana um dia que a gente fica pra planejar. Então a gente chega um pouquinho mais cedo, uma meia hora mais ou menos, a gente senta e tem uma hora de planejamento. E era nesse momento que a gente planejava o que a gente iria fazer durante a semana (...) a estagiária, subia também para ajudar a planejar".

"As reuniões de toda semana contribuiu bastante para o trabalho com Catarina porque foi dentro dessas reuniões que a gente foi entendendo um pouquinho mais da Catarina e podendo trabalhar também um pouco mais. Porque sem reunião e sem essa troca a gente não ia conseguir".

Nesses recortes fica claro, mais uma vez na presente pesquisa, que esses dispositivos apontados por Maria seguem os exemplos dados por Bastos (2003) e Prioste (2006), a respeito dos espaços de escuta e troca entre os professores com o objetivo de acolher angústias decorrentes do cotidiano escolar, permitindo a emergência do conflito para pensar a relação com o aluno em sua singularidade e promover novas saídas para o dia-a-dia com as crianças em situação de inclusão. A presença da estagiária foi outro suporte oferecido que foi ao encontro do que Sekkel (2003) e Fráguas (2003) assinalam em suas pesquisas sobre a existência de um educador que atue junto à criança dentro do ambiente escolar com o objetivo de ajudá-la e trazê-la para o grupo, pois puderam comprovar que essa presença, além dos professores, ajudou a promover mudanças no funcionamento psíquico e social dessas crianças. 
"A parte da enfermagem foi completa. A gente teve palestras, a enfermeira que veio ajudou", mas eu acho que na parte pedagógica a gente poderia ter avançado um pouco mais. A creche, ela... a gente faz um trabalho legal de inclusão mas eu acho que a gente ainda precisa de mais suporte em relação a ... não sei como eu posso dizer... orientação, um curso, não sei... que a gente pudesse trabalhar um pouco mais essa coisa da inclusão pra gente entender um pouco mais. Não que a gente não entenda, a gente faz meio que no instinto, você entende? Mas falta a gente entender um pouco mais o porque de trabalhar essa coisa da inclusão. Não que não seja trabalhado, eu só acho que a gente poderia aprofundar mais, com formação.”.

"(O contato) era mais das crianças com ela quando se aproximavam dela, mas ela seguia com o olhar (...). Tinham algumas crianças que ela até reconhecia, quando elas chegavam ela já sorria, (reconhecia) pela voz, porque ela não via tão nitidamente, ela enxergava, mas não tão nitidamente. Mas ela seguia com o olhar. E a gente percebia que quando chegavam as duas crianças que ficavam muito próximas dela e que ela seguia um pouquinho com o olhar".

"As crianças até tentavam (brincar com ela), pegavam na mãozinha dela, mas não era uma coisa de... por exemplo: no pátio, as crianças ficavam no escorregador, a gente levava ela na areia, tirava o calçado para ela sentir a areia, as crianças ficavam do lado, mas não interagiam muito. Olhavam para a Catarina, falavam alguma coisinha e já saiam".

"Eu acho que esse tempo de trabalho com ela deve ter ajudado a Catarina em algum momento, não sei dizer se o ano todo, se foi válido, mas em algum momento ela deve ter, ah... percebido alguma coisa. Porque eu acho que assim, a mãe dela falava que ela estava sorrindo mais".

"Não sei se foi do jeito totalmente certo, mas dentro do possível a gente foi fazendo e vendo os resultados, que ela ia respondendo a algumas coisas".

É curioso que apenas no final de seu relato, Maria informa que na entrada de Catarina na creche, a equipe da instituição assistiu a uma apresentação sobre a síndrome, com informações precisas sobre as características que a criança apresentava e como a creche poderia ajudá-la. Parece que mesmo com o saber técnico-científico sendo apresentado de maneira tão clara e acessível, ele não serviu para resolver as dúvidas e a apreensão que Maria portava ao receber sua aluna. Então, vemos que Maria, do lugar da histérica, veio denunciar que aquele conhecimento específico não lhe ajudaria a saber como trabalhar com Catarina.

"Quando a Catarina entrou na creche a gente teve palestras com os enfermeiros e eles passaram tudo para a gente, qual era o diagnóstico dela, tudo direitinho, mas é que eu não fiquei muito atenta a isso. Não que eu não estivesse preocupada em como administrar a alimentação, mas eu estava preocupada com outras coisas, com o bem estar dela e como ela iria ficar o grupo. A gente teve uma reunião e foi até passado no datashow com explicação de como eram os cromossomos, mas eu não quis me 
atentar quanto a isso, eu fiquei mais preocupada com o bem-estar dela. Não que a gente não pensasse: 'ai meu Deus e se ela cair?', mas a mãe dela passou essa tranquilidade, então, a partir do momento que a gente via a mãe dela colocando ela, ou então deixando ela de bruços, a gente foi vendo que era possível fazer certas coisas (...) e a mãe foi passando essa tranquilidade e isso foi essencial para o nosso trabalho".

Em contrapartida dessa fala final, temos o momento no qual Maria clama por saberes específicos sobre a inclusão, ao dizer que "falta a gente entender um pouco mais o porquê de trabalhar essa coisa da inclusão". Ao mesmo tempo em que recebe um saber técnico fornecido durante uma reunião de formação dos educadores, queixase da falta de (in)formação sobre a inclusão. A queixa de Maria parece encontrar eco num sintoma social que parte em busca de respostas sobre "modos de fazer" a inclusão. Esse sintoma, muitas vezes surge na fala de professores que lidam diretamente com o trabalho de inclusão escolar e que, sem espaço para compartilhar suas angústias e fantasias a respeito desse tema, são obrigados a expressar seu desconforto através da queixa. No caso de Maria, contudo, esse espaço para desconforto e reflexão foram oferecidos na creche, seja através da figura da psicóloga, que pôde acolher as apreensões inicias de Maria, seja através dos espaços de reunião e troca.

Aqui surge mais um fator importante a ser levado em conta no trabalho com a educação inclusiva. Dado que o conhecimento científico foi fornecido e os suportes institucionais funcionavam a favor das possibilidades de trabalho com a criança, parece que para Maria eles foram insuficientes. Talvez isso se dê pelo fato de que não basta apenas a oferta de suportes, é necessário que haja uma disponibilidade interna e pessoal — a implicação subjetiva - para que o trabalho com a inclusão alcance o seu sucesso. Essa questão será retomada na discussão.

\section{3b André}

Sandra é pedadoga e psicopedagoga, tem trinta e oito anos, trabalha na creche há dezoito anos e foi professora de André que entrou na creche aos três anos de idade e permeneceu lá até completar cinco anos. Enquanto ele esteve no G6, foi aluno de Sandra. Em seu relato é possível conhecer um pouco da passagem de André pela creche, uma criança diagnosticada com Transtorno Global do Desenvolvimento. Veremos em seu discurso o processo pelos quais passaram Sandra e André durante o ano e que ele foi seu aluno. De dúvidas e incertezas, o trabalho foi permeado por 
apostas que permitiram a permanência de André até o final do primeiro ciclo da educação básica na creche pesquisada.

"A criança com quem eu trabalhei diretamente foi o André. Foi uma criança que tinha... um... na verdade assim. Ele tinha uma questão global do desenvolvimento... os psiquiatras diziam que era um autismo. Então, ele entrou na creche com 3 anos, quando eu fiquei com ele ele tinha 5 para 6 anos e foi o último ano dele na creche, pois com a nova regra ele já iria sair".

"Era uma criança que não falava, que usava fraldas, que entrava na sala, mexia nos trabalhos, gostava muito de tinta, tinha um jeito de funcionar muito dele, nessa espera de... ele ouvia algumas coisas e outras coisas não. Ele tinha uma questão com a limitação, quando ele via um carrinho, ele ia correndo, pegava, subia no carrinho, queria correr, queria comer...".

No começo, quando entra uma criança que gente vê que tem questões (...) nesse começo dá um desespero. Você quer entender, você quer saber, quer fazer um trabalho para ele começar a falar, para ele tirar a fralda, (...). E uma criança com uma questão psíquica mais grave, é algo que mexe com todo mundo.”.

No discurso da educadora fica evidente a dificuldade existente no momento de receber uma criança com problemas, sobretudo quando os problemas são psíquicos, segundo a fala de Sandra. Ela vai descrevendo André, um menino que se apresentava numa condição muito diferente das crianças de sua idade, pois usava fraldas, não falava e não conseguia permanecer na sala de aula.

Diante do desconhecido, parece que o caminho esperado era o de que especialistas pudessem entrar na creche e dar explicações, falar sobre aquela criança e, assim, fornecer as receitas de como trabalhar com ela.

Em consonância com as falas enunciadas pelas educadoras da primeira instituição, o discurso veiculado pela creche não parecia buscar a receita de como incluí-lo no grupo ou sobre como trabalhar a sua inclusão. Entretanto, a queixa inicialmente apresentada era frente ao desconhecido, buscava-se o diagnóstico e um modo de fazer o trabalho com a criança acontecer. Sem mencionar a palavra inclusão, o significante "incluir" permeava o discurso da instituição, que buscava respostas sobre os problemas de André.

\footnotetext{
$\underline{\mathrm{S} 1} \rightarrow \mathrm{S} 2 \quad \underline{\text { André deve ser incluído } \rightarrow \quad \text { Os especialistas sabem sobre isso }}$

$\$ a$ Não há garantia da inclusão André desestabiliza o grupo e não está incluído
} 
Contudo, diante da ausência dos especialistas e das respostas às quais Sandra parecia buscar, vemos ocorrer um giro discursivo no qual da queixa sobre "como trabalhar com o André? Os especialistas devem saber" - queixa que se inscreve no discurso do mestre e busca a resposta no discurso do universitário, — passa-se ao enigma “O que fazer com André?”, enigma que passa a buscar a resposta na própria criança:

"Então, você fica com muita expectativa, e na verdade é assim: no começo a gente queria muito que viessem especialistas, que viesse gente, que o psiquiatra pudesse entrar e falar... e depois a gente vê que não é... o André ele tinha uma questão mas, aqui na creche, a gente poderia fazer algo por ele (...) colocá-lo nesse trabalho independente do que ele tivesse."

"Às vezes a gente pensa tanto que vai ajudar (a vinda dos especialitas) e só distancia, porque quem está convivendo com a criança é aqui, é o grupo, somos nós... a gente que está entendendo (o que acontece com ela).”

No momento em que a queixa se transforma em enigma, abre-se espaço para a superação e, portanto, para que se assuma a responsabilidade pelo sofrimento da criança. O discurso analítico que emerge no giro dos discursos produz o lugar de enigma na homogeinização, que na tentativa de achar uma saída geral para um problema particular, acabou por obturar a singularidade de André:

“(...) a gente pensou primeiramente: o tanto que ele aguentava ficar na sala, então a gente colocou um trinco na sala e eu fechava com o trinco e toda hora ele via se a porta estava aberta. E quando ele percebia que ela estava com trinco, ele acabava fazendo outras coisas. Só que tinha um momento em que ele não aguentava mais. Ele começava a chorar, ele emitia alguns sons, precisava sair da sala e precisava de outro espaço.".

Aqui é possível reconhecer que diante da mudança de queixa para enigma, há o reconhecimento de André em sua singularidade. Na emergência da particularidade do caso, ocorre a fratura do processo da mestria institucional. Ao impelir saberes aos especialistas, saberes os quais, tanto Sandra quanto a instituição desconheciam, e ao se deparar com nenhuma resposta sobre como proceder com André, vemos a educadora se lançar num desafio, tendo de elaborar um saber próprio a respeito de sua realidade educacional. Este fato permite um giro discursivo, no qual Sandra passa a agenciar a partir do discurso do mestre, não mais colocando o saber nos especialistas, mas no aprendizado diário com o próprio André, sendo considerado agora em sua singularidade. 
"Então pensamos nessa criança que ela deveria ter um acompanhamento mais individualizado. Porque eram 16 crianças na sala e quando ele saía, não dava para eu sair correndo, ele corria muito pelos quatro cantos da creche, ele era uma criança grande, e ele não voltava rápido. Tinha todo um convencimento para ele voltar e não dava para deixar os outros na sala sozinhos, né?".

"Para estruturar a sala pensando nele também, como ele gostava muito de fotos a gente fez um painel na sala com as fotos de todas as famílias e da família dele também. (...). Ele pegava um pouco, ficava (com as fotos). Ele era uma criança que gostava de ficar entre as almofadas, então nesse canto a gente colocou as almofadas para ele. E isso não foi um projeto, foi pensando nele, como organizar a sala e nessa organização da sala em como organizar um canto em que o André poderia se sentir mais à vontade."

Ao se deparar com o impossível de os especialistas corresponderem com o que se esperava deles (fornecer à educadora o modo de trabalhar com André), Sandra se lança em um novo questionamento e tenta produzir algo diferente. Reconhece que André não é um mero objeto, mas um sujeito, portanto, passa a operar no discurso do mestre, na busca de uma nova produção sem, contudo, permanecer nele.

Parece que para a produção de algo novo ocorrer houve a confrontação de Sandra com seu próprio dizer, pois não obteve a resposta esperada dos especialistas. Diante desta não ocupação do lugar que lhe era designado, Sandra precisou rever a sua queixa e o seu dizer e esse confronto possibilitou o giro do discurso. A partir de seu fazer inventivo, outros recursos puderam ser pensados para ajudar no trabalho com André, entre eles, a entrada das estagiárias.

"Então, pensando, a creche contratou algumas estagiárias da psicologia para acompanhar o grupo de crianças. Quando ele fez 5, veio mais uma, e ela ficava só o período intermediário e aí a gente começou a estruturar um trabalho pensando nele: como fazer?".

"Quando ele saía da sala, elas acompanhavam ele e, basicamente, iam acompanhando para ver até que ponto ele conseguiria fazer tudo aquilo que ele precisava fazer e depois voltar para a sala. No começo, às vezes ele voltava só na hora do almoço. Ficava a manhã inteira fora. (...) em cada lugar que ele passava ele ia fazendo algum tipo de coisa."

"As estagiárias, as duas, foi um suporte imprescindível para esse trabalho poder acontecer e a afinação disso tudo, porque não é fácil ter duas pessoas e depois entrar mais uma, trabalhar em três. E às vezes, o estagiário, ele vem com outra expectativa e a gente tem um trabalho que a gente organiza.".

"Por exemplo, nos dias do projeto, a gente pensava em algo que ele pudesse fazer, que ele pudesse ouvir também."

“(...) ele chegava e a gente tinha feito um trabalho com argila e como ele era uma criança que tinha... ele não é que ele pegava, ele pegava já com força e às vezes 
acabava quebrando o trabalho de uma criança e elas ficavam muito bravas. Então, ir falando para as crianças de como o André tinha uma questão, de a gente ter um pouquinho mais de paciência com ele, de ouvir mais e de entender mais, acho que para elas foi mais significativo ainda."

"Então, quando o André entrava (na sala) e eles queriam preservar alguma coisa, eles diziam: 'olha, André, pode vir', aí eles seguravam bem forte na mão, ele via e tal... e depois eles guardavam.”.

"Tratar dessas questões com as crianças, também de entender o outro, entender a diferença, que tem uma diferença, que não é todo mundo igual, falar das suas diferenças e falar desse caminho que cada um vai seguindo e que tem um tempo de cada um. E o André tinha o tempo dele."

Através destes recortes, vemos a ocorrência do reconhecimento de André em sua singularidade, ou seja, como um sujeito do discurso e com necessidades próprias.

"Um dia, ele estava na sala bem, nenhuma das duas (estagiárias) tinham chegado ainda e ele estava ouvindo a história. Quando ela chegou, ele fez aquela carinha de quem ia chorar e a gente falou: 'olha, já é uma outra questão' e ela disse: 'vou sair, pois vi que ele está bem e ele associou alguma coisa de que eu entro e a gente vai sair e fazer outra coisa' . E a gente começou a perceber isso, que ele fazia certas coisas ... que ele foi percebendo coisas, e que isso é bacana também.”.

Nesse ato de reconhecimento da singularidade de André, ocorre o movimento da valorização das diferenças em grupo. A partir de um espaço criado pela educadora para o questionamento e o entendimento das diferenças da criança em relação ao restante do grupo, o trabalho inclusivo pôde acontecer:

"Quando o André começava a ficar muito impaciente na sala, ele ia passando mesmo e derrubando, jogando as prateleiras, jogando os trabalhos no chão, ele tinha que sair, mesmo. Era algo que ele tinha que sair. Então eles foram segurando isso, o grupo foi ajudando. Acho que isso foi muito importante para o grupo: entender isso, né?".

“(...) eles (as crianças) estavam jogando e ele (André) pegava a caneta e ia em cima do jogo, fazia todo o percurso com uma caneta, e eles já iam sinalizando. Então, quando tinha jogo, eles guardavam as canetinhas, pois eles sabiam que o André ia pegar e desenhar em cima do jogo.".

Também podemos identificar na fala de Sandra a possibilidade de uma resignificação de seu fazer educativo com André e com o grupo como um todo. Parece que reconhecê-lo em sua singularidade permitiu que as diferenças pudessem ser faladas e, consequentemente, respeitadas, o que abriu espaço para que novas formas de estar em grupo surgissem, como veremos a seguir: 
"Tinha algo também porque (...) a areia para ele era muito significativa, então ele se lambuzava. E essas crianças foram podendo também um dia experimentar se molhar, experimentar ficar um pouquinho na areia... e isso tudo foi um percurso que no final do ano desembocou nisso, de tentar entender (...) e achar uma graça nisso junto com o André, e ele gostava. Acho que isso foi algo muito bacana no desenvolvimento para essa idade para estar junto, foi um norte."

Os espaços de troca destinados a pensar e refletir sobre a prática educativa com André tambem permitiram que a educadora, na companhia das estagiárias, se desse conta de sua implicação subjetiva naquilo que, num primeiro momento, era apenas visto como um problema exclusivo da criança. Frente ao que, de início, ela só poderia questionar ou clamar por modos de fazer o trabalho com André:

"Nós trocávamos no espaço formal, nas reuniões de dupla, onde a gente trocava e fazia coisas, e tem o olhar do dia-a-dia (...), como ele chegava, do jeito que ele adentrava, como ele ia ficando, se tomava o suco, se não tomava, a gente ia percebendo: (...) 'ele está tentando falar mais coisas hoje', ou não, 'chegou foi direto para a areia, para a água, não quer ouvir...'."

Pode-se levar em consideração que nos espaços de troca, onde ocorre a circulação da palavra, existe uma rede discursiva, na qual a fala pode assumir novos significados na medida em que a educadora se vê confrontada com o seu próprio dizer (como ocorreu ao clamar pelos especialistas que não vieram lhe dar as respostas) e com a impossibilidade do outro (no caso, os especialistas) de responder do lugar que lhe foi designado no discurso.

"Então, afinar o trabalho com mais duas que, é uma educadora da manhã e outra da tarde, com as estagiárias também foi um trabalho intenso, de conversar, falar de horários, falar de entrada, de como abordar (...) como o André pode, até onde ele não pode, isso tudo foi muita conversa, muita discussão e muita reunião. E a gente conseguiu, de certa maneira, nós quatro, afinar esse trabalho.".

"Para ter trabalho tem que ter afinação e para ter afinação tem que ter muita conversa, muita disponibilidade. Eu acho que foi essa disponibilidade que fez o trabalho com o André ir por um caminho bacana, porque sem a afinidade dos adultos, não anda. Isso a creche ajudou muito."

Por fim, temos no relato de Sandra, algumas pistas que indicam o caminho para o sucesso da inclusão escolar: a possibilidade dos espaços de troca da prática educativa, o reconhecimento da criança em sua singularidade e, portanto, reconhecimento da crianca como um sujeito do discurso. 
"Porque pode vir alguém, pode vir um estagiário e ele ficar só com a criança, não ter um trabalho de inclusão mesmo. E essas apostas foram o que foram fazendo uma diferença no trabalho com ele, de ir apostando o tanto que ele conseguiria ficar, o tanto que ele poderia fazer, e apostando que ele poderia participar ou não participar naquele momento."

“(...) somos nós que vamos tentando e fazendo esse trabalho diário. Isso é muito difícil porque a gente quer um retorno, a gente quer ver uma resposta imediata e, na verdade, o resultado é o que a gente vai fazendo no dia-a-dia. (...) De ficar pensando no que ele podia e de ficar apostando. Foram essas apostas que foram crescendo e fazendo o trabalho ficar significativo."

Esses elementos foram essenciais para que a leitura da singularidade de André fosse reconhecida como um dos fatores principais e essenciais para o alcance do sucesso de seu processo inclusivo:

"Foi o dia-a-dia e o trabalho sendo construído nesse caminho de ir percebendo as dicas que ele ia dando. Entendendo essas dicas, introduzindo essas dicas e analisando, vendo e apostando, foi isso que fez com que ele ficasse tão marcante para a gente na creche."

Até aqui, temos um material valioso e fundamental que contribui sensivelmente para a elaboração de alguns indicadores de sucesso da inclusão escolar. Veremos, daqui por diante, como esses aspectos se articulam e podem fornecer um material competente para que o trabalho com a inclusão escolar possa alcançar o seu sucesso. 


\section{8}

\section{Discussão}

Para prosseguirmos com a discussão, retomaremos o material produzido pela análise dos relatos. Podemos observar que, ao final da análise de cada uma das entrevistas realizadas, temos em mãos um rico material através do qual pudemos identificar alguns aspectos discursivos que se repetem nos recortes apresentados. Apectos que, de acordo com o que a teoria lacaniana nos fornece como base para a análise dos discursos, podemos tomar como possíveis indicadores de sucesso da inclusão escolar.

Uma característica relevante da teoria lacaniana dos discursos é sua abertura a mudanças de posição do sujeito. Essa possibilidade de mudança aponta para a participação das funções (representadas pelas letras), dos lugares (representados pelos quadrantes), das relações (representadas pelas setas de implicação e barras) e de um operador (representado pelo quarto de giro que marca qualquer mudança de discurso) na estrutura subjetiva. O giro discursivo, portanto, é o quarto de torção que possibilita a transformação de um discurso em outro levando, por conseguinte, à mudança de posição discursiva do sujeito no discurso, sem deixar de levar em conta que posição discursiva é uma espécie de jogo de ocupação e atribuição de lugares designados pelos enlaçamentos sociais a partir da lógica dos discursos. Contudo, é preciso lembrar que as posições ocupadas nos discursos são efêmeras, o que torna impossível alguém se sustentar na rede intersubjetiva, rede que nos vincula, permanecendo sempre na mesma posição. A teoria dos quatro discursos introduz a escrita algébrica dos discursos que tem como efeito imediato o fato de que a função se descola do personagem.

Desse modo, tomaremos a princípio como um dos eixos moduladores dos indicadores o que a teoria lacanaina denominou por giro discursivo, pois veremos que, a partir desta ocorrência, obtivemos efeitos significativos que nos levaram a considerá-los indicadores de sucesso no que tange ao tema da inclusão escolar.

Levantaremos os pontos de intersecção dos recortes, que já foram apontados no capítulo 7, buscando percorrer os indícios centrais que se apresentam nos relatos colhidos sobre a prática com a inclusão escolar de tais alunos. Esse levantamento tem como objetivo demonstrar recorrências que, se levadas em consideração ao trabalho 
com a educação inclusiva, podem levar ao sucesso de cada caso particular. Contudo, faz-se importante frisar que essa apresentação está longe de possuir a pretensão de esgotar o tema ou de que toda a complexidade da questão esteja aqui retratada.

Pudemos observar que em quatro das seis entrevistas identificamos situações reveladas nas falas das educadoras que indicam o momento no qual as respectivas crianças passaram a não mais assumir o lugar de destinatário ao qual os agentes dos discursos lhes remetiam: o de crianças incluídas no sistema escolar. Encontramos nas falas de Ana (7.2a; 7.2b), Renata (7.2c) e Luciana (7.2d) situações que tornam evidente que as formações discursivas correntes atribuem a essas crianças o lugar de objeto, pregando um saber sobre como proceder com a inclusão - mantendo-as inseridas no grupo a qualquer custo - estava distanciando o processo inclusivo de seu sucesso. Isso porque, ao não corresponderem à expectativa de serem alunos pertinentes ao contexto escolar, com o lugar que lhes era designado (de pertencentes e participativas), essas crianças apontaram para uma fratura na mestria do discurso institucional.

Vemos que na impossibilidade de continuarem respondendo do lugar que lhes era impingido, algo particular dos casos em questão emergiu, revelando a impossibilidade do imperativo da inclusão ocorrer a despeito das singularidades destas crianças. Ou seja, quando o discurso corrente quer apenas que as coisas funcionem, sem se dar conta da verdade (no caso aquilo que podemos considerar como singular e particular em cada um dos relatos apresentados), o outro não assume o lugar de destinatário desta formação discursiva. Nessas ocorrências, o que emerge são as características particulares de cada uma das crianças, gerando a possibilidade de serem olhadas e reconhecidas como sujeitos singulares.

Podemos, então, levantar a hipótese de que quando o outro - no caso a criança - não realiza o ideal decorrente do lugar de destinatário da formação discursiva agenciada pelo discurso do mestre - que busca fazer da inclusão um imperativo, a despeito de cada criança singular — , temos um primeiro indicador de sucesso. Nessa não correspondência, verificamos que algo particular de cada um dos quatro casos emergiu, possibilitando o reconhecimento de cada uma das crianças em suas respectivas singularidades, necessidades e características.

O reconhecimento da criança como um sujeito do discurso e, portanto, singular, foi uma ocorrência que apareceu em todos os relatos analisados $(7.2 \mathrm{a} ; 7.2 \mathrm{~b}$; $7.2 \mathrm{c} ; 7.2 \mathrm{~d} ; 7.3 \mathrm{a} ; 7.3 \mathrm{~b}$ ), principalmente quando as falas enunciam a busca pela direção 
do trabalho no aprendizado diário com as crianças em situação de inclusão, trabalho pautado no aluno singular e não mais nos especialistas e nos manuais. Parece que a impossibilidade da criança em corresponder às expectativas de ser incluída de maneira genérica e universal (um único modo de fazer comum a todos) traz a possibilidade de se buscar, no dia-a-dia, as maneiras viáveis de se efetuar o trabalho inclusivo.

Também pudemos reconhecer a repetição de outro aspecto que nos leva a entendê-lo como mais um facilitador do alcance do sucesso da inclusão. Quando ocorre uma espécie de confrontação do agente discursivo com o seu próprio dizer que muitas vezes aparece disfarçado em seus atos (no seu próprio fazer educativo), ocorrem mudanças nas atitudes dirigidas a essas crianças. Podemos levar em conta que essas evidências, partes integrantes da rede discursiva, demonstram momentos nos quais a fala pôde assumir novos significados à medida que as educadoras, agentes dos discursos, se viram confrontadas com os seus próprios dizeres.

Vemos isso ocorrer em quatro das seis entrevistas $(7.2 \mathrm{~b} ; 7.2 \mathrm{c} ; 7.2 \mathrm{~d} ; 7.3 \mathrm{~b})$ Esses atos de confrontação acabaram gerando, por conseguinte, uma ressignificação nos atos educativos, que promoveram mudanças em suas atitudes dirigidas às crianças. Essa confrontação com o próprio dizer é o que já introduzimos anteriormente, com o que Lacan (1958) fez questão de marcar a diferença em relação à interpretação. Tal confrontação pode acontecer quando o sujeito agente do discurso depara-se com uma não-procedência de seu dizer. No caso da fala de Ana sobre Carolina (7.2b), temos um exemplo claro dessa confrontação, uma vez que o discurso inicia-se definindo Carolina como uma criança muito tranquila, pertinente e incluída no grupo, ao passo que, num dado momento, isso deixa de ocorrer, sendo enunciado através do considerável atraso cognitivo que ela passou a apresentar. Essa situação gerou um quadro de confronto a partir do qual Ana que teve que se deparar com a sua implicação no trabalho com Carolina e buscar novas maneiras de trabalhar a sua inclusão. O mesmo parece ter ocorrido segundo os fragmentos das falas de Renata (7.2c), Luciana (7.2d) e Sandra (7.3b).

Também foi possível observar nos fragmentos das seis entrevistadas que, ao se darem conta de suas implicações no trabalho com seus respectivos alunos, houve a possibilidade de uma ressignificação no fazer educativo de cada uma delas. Vemos em 7.2a; 7.2b; 7.2c; 7.2d; 7.3a; 7.3b que, como efeito dos giros discursivos, diferentes atitudes e práticas passaram a ser assumidas em relação às crianças em situação de 
inclusão. Mudanças em relação à permissão para estar fora da sala e do grupo (7.2a; $7.2 \mathrm{c}$ ), atividades de cunho pedagógico adequadas às necessidades da criança (7.2b), entrada de mais um adulto na composição dos educadores responsáveis pela criança e o grupo (7.2b; 7.2c; 7.2d; 7.3a; 7.3b) e chamar a família em busca de sua implicação com a criança em consonância com a escola (7.2d), foram algumas das modificacões no ato educativo relatadas pelas educadoras.

Por último, mas não menos importante, identificamos um indicador o qual Voltolini (2001) denominou como sendo a passagem da queixa para o enigma, ou seja, quado ocorre uma transformação da queixa (sofrimento/gozo) em um questionamento "no qual o sujeito se sinta implicado no que sofre/goza, responsabilizando-se (não se culpando) por aquilo que é da ordem do ato" (Voltolini, 2001, p. 110).

Desse modo, encontramos a passagem da queixa para o questionamento em quatro recortes $(7.2 \mathrm{a} ; 7.2 \mathrm{~d} ; 7.3 \mathrm{a} ; 7.3 \mathrm{~b})$, quando as educadoras, no lugar de agente discursivo do lamento, passam a se questionar sobre o que fazer com seus alunos. Nas falas de Ana em relação a Luís (7.2a), de Luciana (7.2d), de Maria (7.3a) e Sandra (7.3b) podemos identificar que, a partir do momento em que passam a se questionar e a não mais a se queixar (sobre as dificuldades de se trabalhar com aquelas crianças e responsabilizando-as exclusivamente por seus problemas), a possibilidade de um saber inédito irrompe no aprendizado diário com cada uma dessas crianças. Seja na possibilidade de se construir um saber novo como no caso de Ana com Luís, no reconhecimento de Maria em relação às possibilidades de cuidado com Catarina, no caso de Sandra que modificou sua busca por saberes com os especialistas em uma construção diária com André, seja na atitude de Luciana ao buscar maior implicação da família de João e de se recusar a permanecer no lugar se queixa permanentemente da ausência da família na escola.

Até o momento, foi possível conceber 5 indicadores de sucesso da inclusão escolar sob o efeito do eixo norteador do giro discurviso, de acordo com o que introduzimos acima:

1. o sujeito (a criança) não realiza o ideal decorrente do lugar de destinatário que a formacão discursiva lhe designa;

2. a criança pode ser reconhecida e/ou valorizada em sua singularidade (como um sujeito do discurso);

3. ocorrência de confrontação do educador com o seu próprio dizer; 
4. abertura à possibilidade de uma ressignificação do fazer educativo em relação às crianças em situação de inclusão;

5. transformação da queixa em enigma.

De acordo com o que foi apresentado na sessão 2.2 sobre a perspectiva psicanalítica da inclusão, vemos que esta teoria propõe uma disjunção entre possível e impossível. Dados os aspectos apontados nas entrevistas (e citados acima), encontramos recorrências de que a possibilidade do trabalho leva ao sucesso da inclusão escolar.

O que pretendemos demonstrar através dos aspectos colhidos nas entrevistas é que, se os educadores encontram-se implicados com o que é possível realizar no diaa-dia e no aprendizado com a criança singular — no que é possível ser feito - o processo inclusivo é caracterizado como sucesso. Ou seja, aquilo que permanece no âmbito do ideal está destinado ao fracasso. Mas, de maneira interessante, aquilo que se abre para as possibilidades tem maiores chances de alcançar o sucesso. As entrevistas, portanto, fornecem dados que nos servem para a caracterização do possível como sucesso da inclusão escolar.

Retomando o percurso deste trabalho, nós partimos da introdução das mudanças de paradigmas sobre a inclusão no Brasil, apresentamos uma concepção sociológica totalitarista sobre o tema e, na sequência, introduzimos a Psicanálise, que propôs não apenas a disjunção entre o possível e o impossível como também a maneira pela qual pode-se operar com essa disjunção. Dessa forma, ficou evidente que essa disjunção tem consequências. $\mathrm{O}$ que pretendemos mostrar até aqui é que na medida em que o trabalho é possível de acontecer, os envolvidos o caracterizam como bem-sucedido. Esse é o grande dado que pudemos obter da análise das entrevistas realizadas: na medida em que o possível se realiza, há um registro de sucesso. É, portanto, no après coup que tais registros podem ser reconhecidos e validados como sucesso.

Temos, consequentemente, a introdução de mais um indicador, o sexto, que contribui para o alcance do sucesso da inclusão escolar: o de trabalhar na linha da possibilidade (e não na do ideal). Todavia, o eixo que norteia e subjaz a esse novo indicador não é o giro discursivo (eixo, este, que subjaz aos outros cinco indicadores), mas a disjunção possível/impossível introduzida pela teoria psicanalítica.

A Psicanálise, como vimos, introduz o princípio de que tudo incluir é impossível, de que não deixar restos é um ideal (portanto, impossível) e que isso 
possui diferentes formas de ocorrência. Tem-se então uma maquinaria discursiva que serve ao ideal: formações discursivas que agenciam como mestre (DM) ou universitário (DU) e a maquinaria que serve ao possível discurso da histérica (DH) e ao discurso do analista (DA). Nem melhores e nem piores, apenas diferentes e que conduzem a finalidades distintas.

Aqui temos o que a Psicanálise nos fornece um eixo valioso que permite a leitura da articulação entre o possível e o sucesso.

É curioso, contudo, o fato de que durante a pesquisa só tenhamos encontrado indicadores de sucesso e não de fracasso. Também podemos discutir essa incidência a partir do viés psicanalítico, uma vez que ele nos traz a ideia de que o ideal de inclusão carrega uma meta de que nada reste. Isto posto, a orientação da mestria segue a linha de fazer com que o ideal de que nada reste se cumpra. Então, frente a isso, qualquer ocorrência de um não-funcionamento pode ser visto e reconhecido como um fracasso e tem de ser elidida de qualquer relato sobre o trabalho inclusivo realizado.

Mas não podemos deixar de levar em consideração que o fato de não termos encontrado nenhum indício de fracasso nas entrevistas possa ser um viés da pesquisadora. Desse modo, precisamos considerar três pontos importantes para se chegar a algumas aproximações da resposta sobre o não-encontro com os indícios de fracasso: a primeira, parte do fato de a pesquisa só ter ido em busca de evidências de sucesso; a segunda parte do fato de a pesquisadora ser membro hierárquico da primeira instituição pesquisada e por esse motivo as entrevistadas só enunciaram as ocorrências de sucesso; e a terceira e última, parte do fato de que, as pessoas em geral, não falam sobre aquilo que elas consideram como fracasso.

Em relação a primeira hipótese, ela pode ser pensada a partir da maneira como a segunda instituição pesquisada foi escolhida. A escolha foi feita com base no conhecimento prévio da pesquisadora sobre a instituição, que foi construída e (re)conhecida - em uma tese de doutorado - como um ambiente inclusivo (Sekkel, 2003). A segunda hipótese parece não se sustentar, uma vez que as ocorrências de sucesso não ficaram circunscritas somente aos relatos da instituição da qual a pesquisadora faz parte, elas se repetiram e foram enunciadas nas entrevistas da segunda instituição, na qual a pesquisadora era uma "estrangeira". Quanto à terceira e última hipótese, não temos materiais suficientes para discutir essa questão. Entretanto - apesar de não nos terem fornecido os motivos - o fato de uma das educadoras entrevistadas na primeira instituição ter desistido de participar da pesquisa pode ser 
um elemento que nos sirva para pensar sobre o fator de que as pessoas não falam sobre o que não consideram sucesso, levando em conta o dado introduzido pela Psicanálise de que a impossibilidade leva ao fracasso.

Outro fator relevante para ser refletido em relação aos indícios de fracasso que ficam elididos dos relatos deve-se à entrevista de Ana sobre Carolina (7.2b), uma vez que nenhuma informação sobre os laços sociais com as crianças de seu grupo foi mencionada. Como dissemos anteriormente, pode ser que esse tema não seja um obstáculo para o processo inclusivo de Carolina ou, ao contrário, pode ser que seja um grande obstáculo ainda visto como intransponível e, por esse motivo, colocado de fora do relato fornecido pela educadora. Da mesma maneira, continuamos sem dados suficientes que corroborem uma maior investigação deste assunto, mas é interessante pensar que algo tão essencial para uma criança na educação infantil — o brincar e os laços sociais — não tenham sido se quer mencionados nos relatos sobre essa criança.

Contudo, permanece como pano de fundo uma possível discussão sobre o fracasso. Isso porque, ainda que ele não tenha surgido e nem sido mencionado nas entrevistas, se retomarmos as ideias freudianas sobre o sentido antitético das palavras primitivas (1910), quem fala de sucesso, inevitavelmente considera a ocorrência do fracasso. São, necessariamente, "os dois lados de uma mesma moeda", uma polaridade, bem como o possível e o impossível.

A preocupação central deste trabalho recaiu, como visto, sobre o que os profissionais envolvidos consideram ser sucesso em seus trabalhos, o que acabou por deixar de fora a questão em torno do que eles caracterizavam como sendo fracasso.

No entanto, dada a disjunção que a Psicanálise opera entre possível e impossível, podemos levantar a hipótese de que os indicadores das possibilidades podem levar ao sucesso dos processos inclusivos. Em decorrência disso, podemos supor como indicador de fracasso (aberto para investigações futuras) uma hipótese de que as pessoas caracterizam como fracasso aquilo que termina por ficar fora do escopo do possível, aquilo para o qual o ideal e, portanto, impossível contribui significativamente.

\section{Sobre as circunstâncias institucionais}

$\mathrm{Na}$ introdução deste trabalho, realizamos uma revisão de literatura que teve por objetivo investigar as menções ou não sobre indicadores de sucesso na inclusão escolar. No processo de revisão, foi possível identificar algumas contingências 
significativas que, de acordo com as pesquisas citadas, foram importantes para o alcance de sucesso dos processos inclusivos descritos uma cada uma delas.

$\mathrm{Na}$ pesquisa de campo realizada para a presente pesquisa, pareceu existirem algumas circunstâncias favorecedoras das operações necessárias para o encaminhamento da impossibilidade para a possibilidade, ou seja, para o sucesso, que parecem ir ao encontro do que propuseram algumas das pesquisas apresentadas na introdução, como retomaremos a seguir.

Rahme (2010), Leodoro (2008) e Sekkel (2003) colocam a questão de que apenas os manuais e decretos não são suficientes para que a inclusão escolar aconteça, evidenciando aspectos de fracasso quando as instituições tentam fazer a inclusão somente com base nesses materiais. Parece que Maria (7.3 a) deixa isso claro quando nos revela, ao final da entrevista, que antes de Catarina entrar na creche toda a equipe da instituição havia recebido instruções e uma breve explicação sobre a síndrome da criança e, portanto, sobre alguns cuidados necessários que deveriam ser tomados em relação a ela. No entanto, apesar desse saber especializado ter sido inicialmente apresentado a Maria, ela demonstra que ele foi insuficiente para que ela pudesse efetivamente realizar um bom trabalho com Catarina. Em sua fala, vemos que somente no trabalho diário com a criança é que ela pôde reconhecer que havia de fato um bom trabalho sendo feito. Podemos identificar na fala de Sandra (7.3b) o reconhecimento de que ficar no aguardo dos saberes de manuais e/ou de especialistas leva a um distanciamento entre os educadores e a criança. Para evitar esse distanciamento, as autoras deixam claro como um possível indicador de sucesso a necessidade de reflexão a respeito da prática educativa inclusiva que vem acontecendo nas escolas regulares para que, a partir disso, a inclusão possa ser pensada e praticada de acordo com a realidade que se apresenta, ou seja, de acordo com as possibilidades que se apresentam no dia-a-dia.

Bastos (2003) e Prioste (2006) abordam a necessidade de existir um espaço de escuta e troca entre os professores com o objetivo de acolher angústias decorrentes do cotidiano escolar e de promover novas saídas para o dia-a-dia com as crianças em situação de inclusão. Essa proposta aparece nos relatos de Ana (7.2a), de Renata (7.2c), de Maria (7.3a): o reconhecimento de um dispositivo fornecido pelas instituições nas quais trabalham e consideram essencial para a condução do processo inclusivo: as reuniões coletivas que ocorrem durante a rotina escolar, com o objetivo 
de compartilhar e refletir sobre as práticas cotidianas e as dúvidas. Como bem disse Sandra (7.3b) "são espaços que ajudam a alinhar e a afinar o trabalho" (sic).

Anhão (2009) e Rahme (2010) constataram que a convivência entre pares traz contribuições significativas tanto para o desenvolvimento infantil dos protagonistas destas relações, quanto para a produção e o reconhecimento de singularidades, deixando claro o indício de sucesso. Encontramos nas falas de Ana (7.2a), de Maria (7.3a), de Sandra (7.3b) evidências importantes sobre as trocas entre pares e a possibilidade destas crianças serem reconhecidas como sujeitos singulares e poderem, portanto, serem respeitadas com suas diferenças.

Emilio (2004), Sekkel (2003) e Fráguas (2003) evidenciam a importância de dispositivos internos - trocas multi e interdisciplinares, implicação da família e acompanhamento terapêutico — nas instituições que favoreçam o trabalho com a inclusão, apontando tais medidas como um fator de sucesso. Nos relatos de Ana sobre Carolina (7.2b), de Renata (7.2c), de Luciana (7.2d), de Maria (7.3a) e de Sandra (7.3b) podemos identificar a importância dada à entrada de mais um adulto (seja como estagiário ou como acompanhante pedagógico) para ajudar no trabalho com seus alunos, pois contribuíram para efeitos sgnificativos, nomeados por todas como fatores de sucesso nos processos inclusivos destas crianças. Nas falas de Renata (7.2c) e de Maria (7.3a) vemos a valorização da possibilidade de troca de informações e conversas com as equipes e profissionais que se ocupam destas crianças fora da escola. E, por fim, é possível reconhecer nos relatos de Luciana (7.2d) e de Maria (7.3a) a importância dada à implicação da família. Em suas falas, quando as famílias se implicaram com seus filhos e com o trabalho escolar realizado com eles, mudanças significativas puderam acontecer.

Temos aqui contingências das expressões daquilo que, dada a leitura realizada das análises das entrevistas, consideramos indicadores de sucesso da inclusão escolar. Portanto, as expressões acima mencionadas parecem favorecer o encaminhamento da impossibilidade para a possibilidade. Entretanto, precisamos levar em consideração o que afirmaram Kupfer e Voltolini (2005) a respeito do conjunto de índices encontrados para formarem o protocolo dos indicadores:

Nessa discussão, percebe-se que o indicador é como um signo que se relaciona com os demais numa rede discursiva ou em uma lógica simbólica, cuja leitura baseia-se nos eixos teóricos em torno dos quais eles foram construídos. Assim, deve-se lembrar que os indicadores, separadamente, não indicam nada. Precisam estar relacionados 
entre si para que possam apontar a lógica do eixo n?o qual estão articulados (Kupfer e Voltolini, 2005, p. 360).

Ou seja, não temos como afirmar que individualmente cada indicador pode levar ao sucesso, ou que somente as contingências institucionais podem encaminhar cada caso para a obtenção de seu sucesso. Entretanto, temos em mãos um material que nos fornece dados preciosos para refletirmos sobre as possibilidades de um trabalho com inclusão escolar alcançar seu sucesso.

O objetivo principal deste trabalho era o de partir de aspectos discursivos para constituir indicadores de sucesso, lembrando que um indicador

"tem sempre que ser considerado uma posibilidade e nunca como uma necessidade de associação com a condição que se pretende indicar" (Campana et al., 2012, p. 5).

Portanto, tínhamos como objetivo formular os indicadores aqui apresentados como aqueles que rompem com a circularidade do impossível, abrindo para a construção do possível na inclusão escolar. 


\section{9}

\section{Considerações Finais}

Nesta pesquisa procuramos investigar indícios de sucesso no trabalho com a inclusão escolar na contemporaneidade.

A partir do referencial teórico psicanalítico, mais precisamente a teoria lacaniana dos quatro discursos, pesquisamos, a partir de relatos colhidos com educadoras de educação infantil, os aspectos referentes às situações de sucesso dos processos inclusivos mencionados.

$\mathrm{Na}$ introdução deste trabalho, realizamos uma revisão de literatura em trabalhos de pesquisa que abordavam o tema da inclusão escolar. Durante esse processo, revelou-se que noções sobre o sucesso da inclusão são constantemente mencionados, porém sem serem nomeados, o que nos abriu a possibilidade de realizar a presente pesquisa, que buscou não apenas colher os dados da ocorrência de sucesso, como também elencar e elaborar indicadores de sucesso do trabalho inclusivo.

Através dos prismas da Psicanálise e da Educação, partimos para um panorama histórico da inclusão, buscando uma compreensão mais abrangente a respeito do que é chamado hoje por educação inclusiva, apresentando as perspectivas teóricas atuais que embasam esse tema. Vimos que, para que o trabalho com inclusão ocorra, é preciso muito mais do que medidas político-administrativas, é necessário que o sistema escolar sustente, acompanhe e promova aquilo que uma criança necessita em sua singularidade. É fundamental reconhecer que permanecer em busca do ideal de inclusão (bem como o de educação) pode nos prender nas impossibilidades do trabalho efetivamente acontecer. A perspectiva psicanalítica nos trouxe uma ampliação do olhar para a inclusão, revelando-se uma ferramenta importante para discutir a natureza das diferentes ocorrências da inclusão, dentre elas os indicadores de sucesso.

No capítulo seguinte, buscamos entender as relações estabelecidas entre os seres humanos quando esses laços envolvem indivíduos e suas diferenças. Buscamos refazer o caminho traçado por Freud $(1919,1921,1930)$ sobre o laço social e a maneira como os indivíduos se relacionam com a diferença, culminando nas idéias de Lacan (1969/1970) sobre a segregação. Nesse trajeto, chegamos a um ponto no qual o questionamento sobre a possibilidade de nomear a diferença se fez inevitável. E a 
resposta por nós encontrada foi a de que quanto mais se tenta nomear e classificar as diferenças, mais corremos o risco de torná-las cada vez mais segregadas.

Restamos com um novo questionamento sobre o que fazer com a tentativa que insiste na classificação da diferença e o que pudemos extrair a partir deste trabalho é que ao invés de se tentar enquadrá-la, seria mais interessante tentar respeitá-la e reconhecê-la, dado o seu caráter de infinitude.

Na seqüência, partimos para o objetivo principal desta pesquisa: constituição de indicadores de sucesso na inclusão escolar. Antes de abordá-los, foi necessário situá-los quanto ao seu conceito e fazer uma apresentação da origem da utilização de indicadores nas pesquisas psicanalíticas. Verificamos que todos os indicadores são permeados por eixos que os modulam, e que os tornam possíveis de serem expressos fenomenicamente. Esse material nos permitiu realizar uma analogia na elaboração dos indicadores de sucesso da inclusão escolar, um novo material que possui a intenção de contribuir com o encaminhamento de cada caso para o seu sucesso.

Em seguida, apresentamos o campo de investigação deste trabalho, a educação infantil, que mesmo sendo um terreno fértil para trabalhar o desenvolvimento infantil, mostrou-se não ser o único campo possível para o alcance do sucesso em relação à inclusão. Isso porque, ao final das análises, pudemos constatar como um dos indicadores para o sucesso da inclusão que devemos trabalhar no terreno da possibilidade e não no do ideal. Esse fator revelou-se importante, pois não restringe o sucesso da inclusão à educação infantil, tornando-a possível desde que os indicadores encontrados neste trabalho estejam presentes na prática cotidiana educacional. Com base na discussão proposta por este trabalho, os indicadores podem ser muito bem empregados em outros contextos escolares (e talvez até sociais) que visem à inclusão, seja ela em qualquer situação de ocorrência.

Dado que o método utilizado para a análise das entrevistas e a coleta de aspectos referentes ao sucesso nos processos inclusivos relatados foi a teoria lacaniana, mostrou-se necessário introduzir e apresentar a teoria para que ela pudesse instrumentalizar a discussão da pesquisa. Nesse captíulo, vimos as possibilidades que a teoria dos discursos proposta por Lacan (1969/1970) nos fornece para analisar as entrevistas e refletir sobre aquilo que o sujeito produz em seu enlaçamento social. Mais do que isso, essa teoria se mostrou estar a serviço não somente da clínica 
psicanalítica, como também das práticas psicanalíticas interdisciplinares, permitindonos dialogar com outros campos do saber, como a educação inclusiva, por exemplo.

No capítulo sétimo, lançamo-nos à análise das entrevistas realizadas com educadoras de educação infantil que nos relataram suas experiências enquanto professoras de crianças que se encontravam em situação de inclusão. Buscamos, percorrer em seus relatos os indícios de sucesso por elas abordados, encontrando o que parecia se repetir em todas as realidades aqui retratadas. Os aspectos a partir dos quais elaboramos os indicadores de sucesso da inclusão escolar corroboram justamente as hipóteses e reflexões aqui lançadas de que não se prender aos ideais de inclusão, trabalhando no campo das possibilidades, levam ao alcance do sucesso inclusivo.

Muito além de encontrar modelos de intervenção na inclusão escolar ou propor novas técnicas, pretendemos, com esta pesquisa, apenas revelar a existência de indicadores para o alcance de sucesso na inclusão escolar, dada a escassez de indicadores — demonstrada na revisão de literatura sobre o tema - que contribuam para o monitoramento dos processos inclusivos.

Certamente, o material resultante desta pesquisa parece ainda estar mais voltado para o campo psicanalítico do que para o campo da educação, fato que nos traz algumas limitações, bem como alguns préstimos. As limitações encontradas dizem respeito a alguns fatores, dentre os quais podemos destacar o fato de ser um grande desafio trabalhar com indicadores construídos a partir da teoria psicanalítica. Segundo Kupfer e Voltolini (2005)

não há consenso em torno da possibilidade de uso de medidas e tampouco em torno da construcão de protocolos clínicos que utilizem indicadores clínicos objetivos com base na psicanálise (Kupfer \& Voltolini, 2005, p. 359),

o que nos faz levar em conta possíveis limites devido ao viés metodológico escolhido que deve, portanto, ser considerado como uma das possibilidades de campos de discussão, não a única e exclusiva. Como préstimos, encontramos um bom encaminhamento da questão sobre a necessidade de elaboração e utilização de indicadores que contribuam para que os processos inclusivos escolares alcancem o seu sucesso.

Chegamos ao fim reconhecendo que novos questionamentos foram lançados para que novas possibilidades de pesquisas possam se debruçar sobre os temas aqui 
levantados. Os pontos abordados, principalmente aqueles detectados a partir das entrevistas com as educadoras, merecem novos desdobramentos e pesquisas futuras, mais direcionadas ao campo educacional e escolar, justamente por mostrarem-se relevantes para que o trabalho com a inclusão escolar atinja o seu sucesso.

Esse foi um estudo exploratório e nosso objetivo está longe de se esgotar aqui. Por ora, muitas perguntas permanecerão em aberto, mas talvez sirvam como pontos relevantes para que futuras investigações as tomem como objetos de estudo acerca do que nomeamos aqui como: indicadores de sucesso da inclusão escolar. 


\section{Referências Bibliográficas}

Ainscow, M. (1998). Educação para todos: torná-la uma realidade. In M. Ainscow, M. Wang \& G. Porter (Orgs.), Caminhos para escolas inclusivas (pp. 11-31). Lisboa: Instituto de Inovação Educacional.

Amaral, L. A. (2002). Diferenças, estigmas e preconceito: o desafio da inclusão. In M. K Oliveira, T. C. Rego \& D. T. Souza (Orgs.), Psicologia, educação e as temáticas da vida (pp. 233-248). São Paulo: Moderna.

Anhão, P. P. G. (2009). O processo de interação social na inclusão escolar de crianças com Síndrome de Down em educação infantil. Dissertação de Mestrado, Faculdade de Medicina de Ribeirão Preto, Universidade de São Paulo, Ribeirão Preto.

Aranha, M. S. F. (2001 março). Paradigmas da relação da sociedade com as pessoas com deficiência. Revista do ministério público do trabalho, 11(21), 1-24.

Bastos, M. B. (2001). Impasses vividos pela professora na inclusão escolar. Estilos da Clínica, 6(11), 47-55.

Bastos, M. B. (2003). Inclusão escolar: um trabalho com professores a partir de operadores da Psicanálise. Dissertação de Mestrado, Instituto de Psicologia, Universidade de São Paulo, São Paulo.

Braga, P. L. (2006). Impasses na inclusão de uma criança com transtornos invasivos do desenvolvimento: sobre a posição da professora. Comunicação apresentada em Psicanálise, Educação e Transmissão, 6, Recuperado em 27 de maio de $2012 \mathrm{de}$ http://www.proceedings.scielo.br/scielo.php?script=sci arttext\&pid= MSC0000000032006000100045\&lng=en\&nrm=abn.

Bernardino, L. M. F. (2006). O que a psicanálise pode ensinar sobre a criança, sujeito em constituição. São Paulo: Escuta.

Booth, T. \& Ainscow, M. (2002). Index para a inclusão: Desenvolvendo a aprendizagem e a participação na escola. (M. P. Santos, trad.). Recuperado em 26 de junho de 2010 de http://www.eenet.org.uk/index_inclusion /Index\%20Portuguese\%20Brazil.pdf.

Boudard, B. (2000). Os quatro discursos no trabalho com os pais. In M. C. M. Kupfer (Org.), Tratamento e escolarização de crianças com distúrbios globais do desenvolvimento (pp. 63-73). Salvador: Ágalma.

Brasil. Congresso Nacional. (1988). Constituição da República Federativa do Brasil. Brasília: Senado Federal.

Brasil. Congresso Nacional (1990). Estatuto da Criança e do Adolescente. Lei n. 8069 de 13 de julho de 1990. Brasília: Diário Oficial da União. 
Brasil. Congresso Nacional (1996). Lei de diretrizes e bases da educação nacionalLDB n. 9394, de 20 de dezembro de 1996. Brasília: Diário Oficial da União.

Brasil. (1997). Conferência Mundial sobre Necessidades Educacionais Especiais: Acesso e qualidade. In Declaração de Salamanca e linhas de ação sobre necessidades educacionais especiais. Recuperado em 20 de julho de 2011 de portal.mec.gov.br/seesp/arquivos/pdf/salamanca.pd

Brasil. Ministério da Educação e do Desporto. Secretaria de Educação Fundamental. (1998). Referencial Curricular Nacional para a educação infantil. Brasília: $\mathrm{MEC} / \mathrm{SEF}$.

Brasil. Ministério da Educação e do Desporto. Secretaria de Educação Fundamental. (1998). Parâmetros Curriculares Nacionais: Adaptações Curriculares. Brasília: $\mathrm{MEC} / \mathrm{SEF} / \mathrm{SEESP}$.

Brasil. Ministério da Educação e do Desporto. (2001). Plano Nacional de Educação. Lei n. 10.172 de 9 de janeiro de 2001. Brasília: Diário Oficial da União.

Brasil. Ministério da Educação. Secretaria de Educação Básica. (2004). Ensino Fundamental de nove anos - Orientações Gerais. Recuperado em 9 de abril de 2011de http://www.portal.mec.gov.br/seb/.../pdf/.../noveanorienger.pdf .

Campana, N. T. C., Lerner, R., Morais, A. S., Tocchio, A. B., Paolo, A. F., Bronzatto, E. M. K. \& Araújo, G. X. (2012 outubro). Uso de Indicadores Clínicos de Risco para o Desenvolvimento Infantil - IRDI na avaliação de bebês com seus pais: contribuições e desafios. Comunicação apresentada no $29^{\circ}$ congresso latino-americano de psicanálise. Recuperado em 25 de novembro de 2012 de http://congresos.pccp.com.ar/fepal2012/preview/pdf-port/310.pdf.

Canguilhem, G. (1990). O normal e o patológico (M. T. C. Barrocas \& L. O. F. Leite, trads.). Rio de Janeiro: Forense Universitária.

Costa, A. M. B. (1998). Introdução. In M. Ainscow, M. Wang \& G. Porter. (Orgs.) Caminhos para escolas inclusivas (pp. 9-10). Lisboa: Instituto de Inovação Educacional.

Charlot, B. (2000). Da relação com o saber: elementos para uma teoria (B. Magne, trad.). Porto Alegre: Artes Médicas Sul.

Crochík, J. L. (2006). Preconceito, indivíduo e cultura. $3^{\mathrm{a}}$ ed. São Paulo: Casa do Psicólogo.

Crochík, J. L., Silva, P. F., Silva, L. B. M., Almeida, R. C. T., Spedo, L., Ferreira, K. D. M. \& Dias, M.A.L. (2011). Análise de um formulário de avaliação de Inclusão escolar. Imagens da Educação, 1(2), 71-87.

De Luca, L. (2001) Labirintos da inclusão escolar. Comunicação apresentada no $3^{\circ}$ Colóquio do LEPSI IP/FE-USP. Recuperado em 12 de julho de 2012 de 
http://www.proceedings.scielo.br/scielo.php?script=sci_arttext\&pid=MSC $0000000032001000300019 \& \operatorname{lng}=\mathrm{en} \& \mathrm{nrm}=\mathrm{abn}$.

Emilio, S. A. (2004). O cotidiano escolar pelo avesso: sobre laços, amarraras e nós no processo de inclusão. Tese de Doutorado, Instituto de Psicologia, Universidade de São Paulo, São Paulo.

Ferrari, M. A. L. D. e Freler, C. C. (2008). Apresentação. In C. C. Freller, M. A. L. D. Ferrari, M. C. \& Sekkel (Orgs.), Educação inclusiva: percursos na educação infantil (pp. 7-15). São Paulo: Casa do Psicólogo.

Fink, B. (1998). O sujeito lacaniano. Rio de Janeiro: Jorge Zahar.

Flach, F. \& Sordi, R. O. (2007). A educação infantil como espaço de subjetivação. Estilos da Clínica, 12(22), 80-99.

Fontanella, B. J. B., Ricas, J. \& Turato, E. R. (2008). Amostragem por saturação em pesquisas qualitativas em saúde: contribuições teóricas. Cadernos de Saúde Pública, 24 (1), 17-27.

Fráguas, V. (2003). Saindo do Ab(aut)ismo: o vivido de uma experiência a partir de um trabalho de acompanhamento terapêutico. Dissertação de Mestrado, Programa de Pós-Graduação em Psicologia Clínica, Pontifícia Universidade Católica de São Paulo, São Paulo.

Freller, C. C. (2010). É possível ensinar educadores a incluir? Estilos da Clínica. São Paulo, 15(2), 326-345.

Freud, S. (1969). A significação antitética das palavras primitivas. In Edição Standard das obras psicológicas completas de Sigmund Freud (J. Salomão, trad., vol. XI, pp. 157-166). Rio de Janeiro: Imago. (Trabalho originalmente publicado em 1910).

Freud, S. (1969). Recomendações aos médicos que exercem a Psicanálise. In Edição Standard das obras psicológicas completas de Sigmund Freud (J. Salomão, trad., vol. XII, pp. 125-133). Rio de Janeiro: Imago. (Trabalho originalmente publicado em 1912).

Freud, S. (1969). Sobre o narcisismo: uma introdução. In Edição Standard das obras psicológicas completas de Sigmund Freud (J. Salomão, trad., vol. XIV, pp. 77-108). Rio de Janeiro: Imago. (Trabalho originalmente publicado em 1914).

Freud, S. (1969). O 'estranho'. In Edição Standard das obras psicológicas completas de Sigmund Freud (J. Salomão, trad., vol. XVII, pp. 235-269). Rio de Janeiro: Imago. (Trabalho originalmente publicado em 1919).

Freud, S. (1969). Psicologia de grupo e análise do ego. In Edição Standard das obras psicológicas completas de Sigmund Freud (J. Salomão, trad., vol. XVIII, 
pp.79-154). Rio de Janeiro: Imago. (Trabalho originalmente publicado em 1921).

Freud, S. (1969). O Ego e o Id. In Edição Standard das obras psicológicas completas de Sigmund Freud (J. Salomão, trad., vol. XIX, pp. 41-51). Rio de Janeiro: Imago. (Trabalho originalmente publicado em 1923).

Freud, S. (1969). Prefácio à juventude desorientada. In Edição Standard das obras psicológicas completas de Sigmund Freud (J. Salomão, trad., vol. XIX, pp. 305-308). Rio de Janeiro: Imago. (Trabalho original publicado em 1925).

Freud, S. (1969). O mal-estar na civilização In Edição Standard das obras psicológicas completas de Sigmund Freud (J. Salomão, trad., vol. XXI, pp. 75171) Rio de Janeiro: Imago. (Trabalho original publicado em 1930).

Freud, S. (1969). Novas conferências introdutórias. In Edição Standard das obras psicológicas completas de Sigmund Freud (J. Salomão, trad., vol. XXII, pp. 13-177), Rio de Janeiro: Imago. (Trabalho original publicado em 1933).

Freud, S. (1969). Análise terminável e interminável. In Edição Standard das obras psicológicas completas de Sigmund Freud (J. Salomão, trad., vol. XXIII, pp. 225-270) Rio de Janeiro: Imago. (Trabalho original publicado em 1937).

Houaiss, A. \& Villar, M. S. (2007). Dicionário Houaiss da Língua Portuguesa. Rio de Janeiro: Objetiva.

Jerusalinsky, A. (1997). A escolarização de crianças psicóticas. Estilos da Clínica, 2(2), 72-95.

Jerusalinsky, A. (1999). Os quatro discursos e a interdisciplina. Psicanálise e Educação: uma transmissão possível, 16,7-13.

Jerusalinsky, A. \& Paez, S. M. C. (2001). Carta aberta aos pais acerca da escolarização das crianças com problemas de desenvolvimento. Escritos da criança, Centro Lydia Coriat, 6,15-21.

Kupfer, M. C.\& Petri, R. (2000). Por que ensinar a quem não aprende? Estilos da Clínica, 5(9), 109-117.

Kupfer, M. C. (2000). Educação para o futuro. São Paulo: Escuta.

Kupfer, M. C. (2001). Duas notas sobre a inclusão escolar. Escritos da Criança, Centro Lydia Coriat, 6, 71-81.

Kupfer, M. C. (2005). Inclusão escolar: a igualdade e a diferença vistas pela psicanálise. In F.A.G. Colli \& M.C.M. Kupfer (Orgs.), Travessias: inclusão escolar a experiência do Grupo Ponte Pré - escola terapêutica Lugar de Vida (pp.17-27). São Paulo: Casa do Psicólogo. 
Kupfer, M. C. \& Voltolini, R. (2005). Uso de indicadores em pesquisas de orientação psicanalítica: um debate conceitual. Psicologia: Teoria e Pesquisa, 21(3), 359-364.

Kupfer, M. C., Jerusalinsky, A. N., Bernardino, L. M. F., Wanderley, D., Rocha, P. S. B., Molin, S. E., Sales, L. M., Satellin, R., Pesaro, M. E. \& Lerner, R. (2009 maio). Valor preditivo de indicadores clínicos de risco para o desenvolvimento infantil: um estudo a partir da teoria psicanalítica. Latin American Journal of Fundamental Psychopathology Online, 6(1), 48-68.

Lacan, J. (2005). O seminário: livro $10 \mathrm{~A}$ angústia.(V. Ribeiro, trad.). Rio de Janeiro: Jorge Zahar Editor. (Trabalho original publicado em 1962/1963)

Lacan, J. (1992). O seminário: livro 17 O avesso da psicanálise. (A. Roitman, trad.). Rio de Janeiro: Jorge Zahar Editor. (Trabalho original publicado em 1969/1970).

Lacan, J. (1993). O seminário: livro 20 Mais ainda. (M. D. Magno, trad.). Rio de janeiro: Jorge Zahar Editor. (Trabalho original publicado em1972/1973).

Lajonquière, L. (2011 julho/novembro). Duas notas psicanalíticas sobre as crianças "com necessidades educativas especiais". Pro-posições, 12(2-3), 35-36.

Leodoro. J. P. (2008). Inclusão escolar e formação continuada: o programa Educação Inclusiva: direito à diversidade. Dissertação de Mestrado, Faculdade de Educação, Universidade de São Paulo, São Paulo.

Lerner, A. B. C. (2010 outubro). A escola inclusiva como uma utopia do século XXI. Comunicação apresentada em $O$ declínio dos saberes e o mercado do gozo. Recuperado em 24 de novembro de 2012 de http://www.proceedings.scielo.br/scielo.php?script=sci_arttext\&pid=MSC0000 000032010000100004\&lng=en\&nrm=abn.

Lerner, R. (2008). Contribuições para o debate sobre a viabilidade de trabalhar como Pesquisador em uma instituição na qual se é membro da equipe de atendimento e aspectos éticos envolvidos. In: Guerriero, I. C. Z.; Schmidt, M. L. S., Zicker, F. (Orgs) Ética nas pesquisas em ciências humanas e sociais na saúde (pp. 223236). São Paulo: Aderaldo \& Rotschild.

Mannoni, M. (1999). A criança retardada e a mãe. (M .R. G. Duarte, trad.). São Paulo: Martins Fontes.

Mannoni, M. (2003). A criança, sua doença e os outros. (M. Seincman, trad.). São Paulo: Via Lettera.

Mantoan, M. T. E. (2012). Caminhos pedagógicos da inclusão. Recuperado em 22 de agosto de 2012, de http://www.educacaoonline.pro.br/index.php?option=com_content\&view=articl e\&id=83: caminhos-pedagogicos-da-inclusao\&catid $=6$ : educacao-inclusiva $\&$ Itemid $=17$. 
Mantoan, M. T. E. (2006). Igualdade e diferenças na escola: como andar no fio da navalha. In V. A Arantes (Org.), Inclusão escolar: pontos e contrapontos (pp. 15-30). São Paulo: Summus.

Mendes, E. G. (2006). A radicalização do debate sobre inclusão escolar no Brasil. Revista Brasileira de Educação,11(33), pp 387-405.

Mrech, L. M. (2001). O mercado de saber, o real da educação e dos educadores e a escola como possibilidade. Tese de Livre Docência, Faculdade de Educação, Universidade de São Paulo, São Paulo.

Nascimento, M. L. B. P. (2008). O percurso da educação infantil para a inclusão: a infância na creche. In C. C. Freller, M. A. L. D. Ferrari \& M. C. Sekkel (Orgs.), Educação inclusiva: percursos na Educação infantil (pp. 39-49). Casa do Psicólogo, São Paulo.

Ormelezzi, E. M. (2006). Inclusão educacional e escolar da criança cega congênita com problemas na constituição subjetiva e no desenvolvimento global: uma leitura psicanalítica em estudo de caso. Tese de Doutorado, Faculdade de Educação, Universidade de São Paulo, São Paulo.

Patto, M. H. S. (2000). A produção do fracasso escolar. Histórias de submissão e rebeldia. São Paulo: Casa do Psicólogo.

Pereira, M. R. (2005). Subversão docente: ou para além da "realidade do aluno". In L. Mrech (Org.), O impacto da psicanálise na educação (pp. 93-116). São Paulo: Avercamp Editora.

Pesaro, M. E. (2011). Alcance e limites teórico-metodológicos da pesquisa multicêntrica de indicadores clínicos de risco para o desenvolvimento infantil. Tese de Doutorado, Instituto de Psicologia da Universidade de São Paulo, São Paulo.

Petri, R. (2003). Psicanálise e educação no tratamento da psicose infantil: quatro experiências institucionais. São Paulo: Annabume-FAPESP.

Pinto, F. S. C. N. (2009). Grupo Mix: um campo de linguagem para a circulação da heterogeneidade. Dissertação de Mestrado, Instituto de psicologia, Universidade de São Paulo, São Paulo.

Prioste, C. D. (2006). Diversidade e adversidades na escola: queixas e conflitos de professores frente à educação inclusiva. Dissertação de Mestrado, Faculdade de Educação, Universidade de São Paulo, São Paulo.

Rahme, M. M. F. (2010). Laço Social e Educação: um estudo sobre os efeitos do encontro com o outro no contexto escolar. Tese de Doutorado, Faculdade de Educação, Universidade de São Paulo, São Paulo. 
Ribeiro, J. M. L. C. \& Bastos, A. (2007). O lugar do analista na extensão da psicanálise à inclusão escolar. Estilos da Clínica, 12(23), 26-35.

Sassaki, R. K. (1997). Inclusão: construindo uma sociedade para todos. Rio de Janeiro: WVA.

Sekkel, M. C. (2003). A construção de um ambiente inclusivo na educação infantil: relato e reflexão sobre uma experiência. Tese de Doutorado, Instituto de Psicologia, Universidade de São Paulo, São Paulo.

Sekkel, M. C. \& Casco, R. (2008). Ambientes inclusivos para a educação infantil: considerações sobre o exercício docente. In C. C. Freller, M. A. L. D. Ferrari \& M. C. Sekkel (Orgs.), Educação inclusiva: percursos na educação infantil (pp. 19-37). São Paulo: Casa do Psicólogo.

Silveira, P. D. (2011). A impossibilidade e a impotência dos discursos. Recuperado em 24 de junho de 2011 de http://www.tempofreudiano.com.br/artigos/detalhe.asp?cod=40.

Voltolini, R. (2001). Do contrato pedagógico ao ato analítico: contribuições à discussão da questão do mal-estar na educação. Estilos da Clinica, 7(10), pp. 101-111.

Voltolini, R. (2002). A desrazão da infância: o discurso analítico e a inclusão. Comunicação apresentada no $4^{\circ}$ Colóquio do LEPSI IP/FE-USP, São Paulo. Recuperado em 11 de julho de 2010, de http://www.proceedings.scielo.br/scielo.php?script=sci_arttext\&pid=MSC0000 000032002000400019\&lng=en\&nrm=abn.

Voltolini, R. (2004a). Psicanálise e inclusão escolar: direito ou sintoma? Estilos da Clínica, 9(16), 92-101.

Voltolini, R. (2004b) A "inclusão" conduz ao pior. Comunicação apresentada no $5^{\circ}$ Colóquio do LEPSI IP/FE-USP, São Paulo. Recuperado em 11 de julho de 2011 de http://www.proceedings.scielo.br/ scielo.php?script $=$ sci_arttext\&pid $=$ MSC0000000032004000100009\&lng=en\&nrm=abn.

Voltolini, R. (2005). A inclusão é não toda. In F. A. G. Colli \& M. C. M. Kupfer (Orgs.), Travessias inclusão escolar: a experiência do Grupo Ponte Pré-escola terapêutica Lugar de Vida (pp. 149-155). São Paulo: Casa do Psicólogo.

Voltolini, R. (2010). Educação inclusiva: revolução ou reforma. Recuperado em 7 de outubro de 2011, de www.letras.ufmg.br/.../pdf\%5CÉtica $\% 20 \mathrm{e} \% 20$ cidadania $\% 5$ CEducação\%20incl usvia.pdf 